\title{
User Manual for Conservation Project Data Base
}

B. A. Garrett-Price

L. L. Fassbender

June 1985

Prepared for the U.S. Department of Energy under Contract DE-AC06-76RLO 1830

Pacific Northwest Laboratory

Operated for the U.S. Department of Energy by Battelle Memorial Institute 


\title{
DISCLAIMER
}

This report was prepared as an account of work sponsored by an agency of the United States Government. Neither the United States Government nor any agency thereof, nor any of their employees, makes any warranty, express or implied, or assumes any legal liability or responsibility for the accuracy, completeness, or usefulness of any information, apparatus, product, or process disclosed, or represents that its use would not infringe privately owned rights. Reference herein to any specific commercial product, process, or service by trade name, trademark, manufacturer, or otherwise, does not necessarily constitute or imply its endorsement, recommendation, or favoring by the United States Government or any agency thereof. The views and opinions of authors expressed herein do not necessarily state or reflect those of the United States Government or any agency thereof.

\author{
PACIFIC NORTHWEST LABORATORY \\ operated by \\ BATTELLE \\ for the \\ UNITED STATES DEPARTMENT OF ENERGY \\ under Contract DE-AC06-76RLO 1830
}

\begin{tabular}{|c|c|}
\hline \multirow{2}{*}{\multicolumn{2}{|c|}{ Printed in the United States of America }} \\
\hline & \\
\hline \multicolumn{2}{|c|}{$\begin{array}{l}\text { Available from } \\
\text { A }\end{array}$} \\
\hline \multicolumn{2}{|c|}{$\begin{array}{l}\text { National Technical Information Service } \\
\text { United States Department of Commerce }\end{array}$} \\
\hline \multicolumn{2}{|c|}{5285 Port Royal Road } \\
\hline \multicolumn{2}{|c|}{ Springfield, Virginia 22161} \\
\hline \multirow{2}{*}{\multicolumn{2}{|c|}{$\begin{array}{l}\text { NTIS Price Codes } \\
\text { Microfiche } A 01\end{array}$}} \\
\hline & \\
\hline \multicolumn{2}{|c|}{ Printed Copy } \\
\hline & Price \\
\hline Pages & Codes \\
\hline 001-025 & $\mathrm{A} 02$ \\
\hline 026-050 & $\mathrm{A} 03$ \\
\hline $051-075$ & A04 \\
\hline 076-100 & A05 \\
\hline $107-125$ & $A 06$ \\
\hline $126-150$ & $\mathrm{~A} 07$ \\
\hline $151-175$ & 108 \\
\hline $176-200$ & $A 09$ \\
\hline $201-225$ & A010 \\
\hline $226-250$ & A011 \\
\hline $251-275$ & A012 \\
\hline $276-300$ & A 013 \\
\hline
\end{tabular}


USER MANUAL FOR CONSERVATION PROJECT DATA BASE

B. A. Garrett-Price

L. L. Fassbender

June 1985

Prepared for

the U.S. Department of Energy

under Contract DE-AC06-76RLO 1830

Pacific Northwest Laboratory Richland, Washington 99352 
SUMMARY................................................... 1

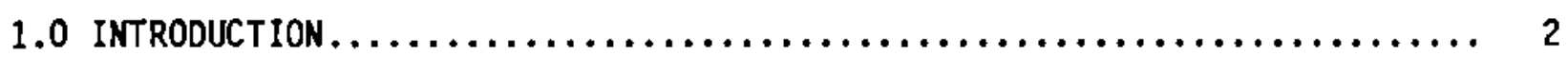

2.0 OVERVIEW OF CONSERVATION PROJECT DATA BASE.................... 5

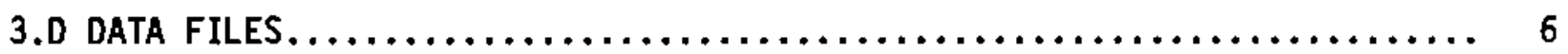

3.1 CEGEN........................................... 6

3.2 Семем........................................... 6

3.3 CEKEY............................................ 6

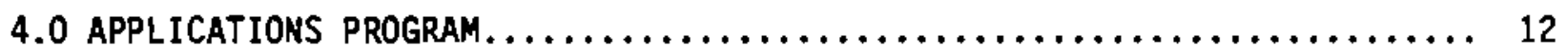

4.1 CEDATA $. \ldots \ldots \ldots \ldots \ldots \ldots \ldots \ldots \ldots \ldots \ldots \ldots \ldots \ldots \ldots \ldots \ldots \ldots \ldots \ldots \ldots \ldots, 12$

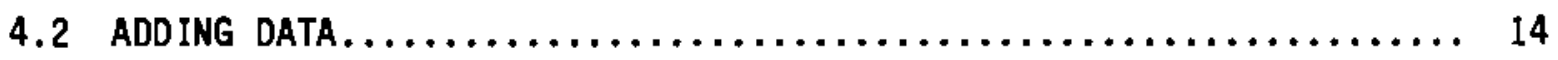

4.2.1 Entering Character and Numeric Data.................. 14

4.2.2 Entering the Project Description, Justification and Addi tional Information.......................... 15

4.3 EOITING DATA $\ldots \ldots \ldots \ldots \ldots \ldots \ldots \ldots \ldots \ldots \ldots \ldots \ldots \ldots, 16$

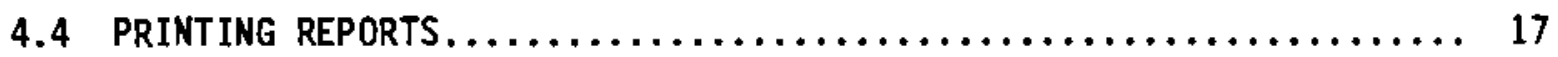

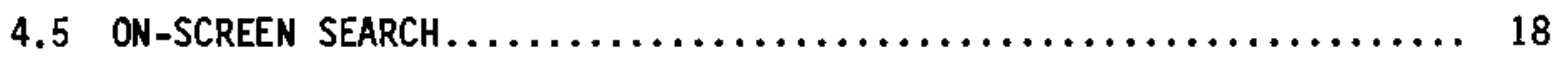

4.5.1 Title Search..................................... 18

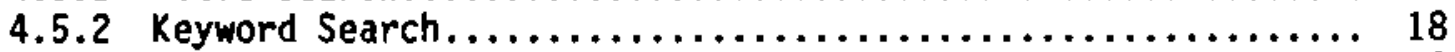

4.5.3 Boolean Search......................................... 18

4.6 HELP $\ldots \ldots \ldots \ldots \ldots \ldots \ldots \ldots \ldots \ldots \ldots \ldots \ldots \ldots \ldots \ldots \ldots \ldots \ldots, 21$

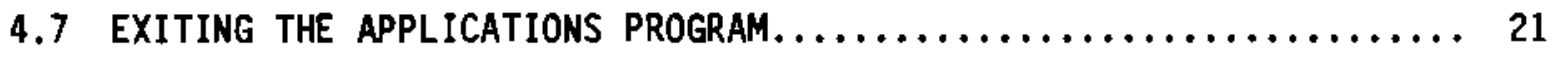

APPENDIX A: PROGRAM LISTINGS $\ldots \ldots \ldots \ldots \ldots \ldots \ldots \ldots \ldots \ldots \ldots \ldots \ldots \ldots \ldots \ldots \ldots \ldots \ldots \ldots$

APPENDIX B: SAMPLE REPORTS $\ldots \ldots \ldots \ldots \ldots, \ldots, \ldots, \ldots, \ldots, \ldots, \ldots, \ldots, \ldots, 1$

APPENDIX C: TROUBLE-SHOOTING GUIDE $\ldots \ldots \ldots \ldots \ldots \ldots \ldots \ldots \ldots \ldots \ldots \ldots \ldots$, C. 1

APPENDIX D: $\quad$ UTILITY FILES. $\ldots \ldots \ldots \ldots \ldots \ldots \ldots \ldots \ldots \ldots \ldots \ldots \ldots \ldots \ldots \ldots, 0.1$ 


\section{FIGURES}

1.1 Conservation Project Data Sheet............................ 3

4.1 CE Data Base Program Structure............................. 13

4.2 Conservation Data Base Banner............................. 22

4.3 CEDATA Program Applications Menu............................ 22

4.4 ADD Program - Program Selection Men....................... 23

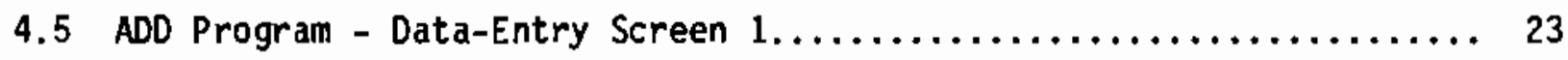

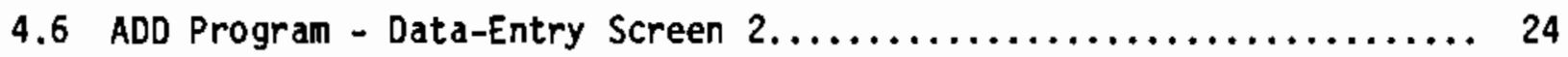

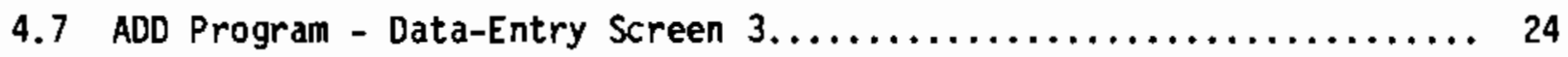

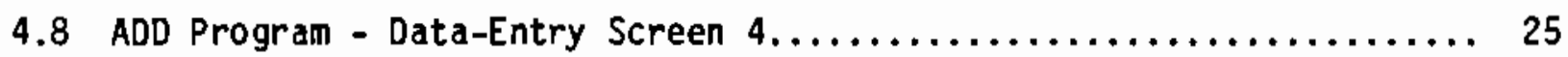

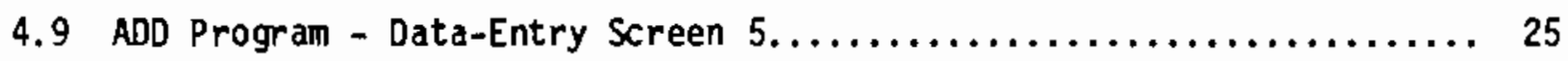

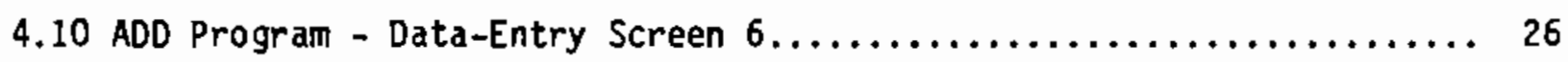

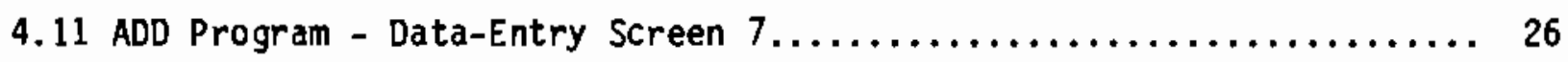

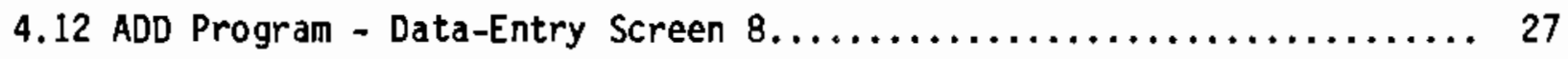

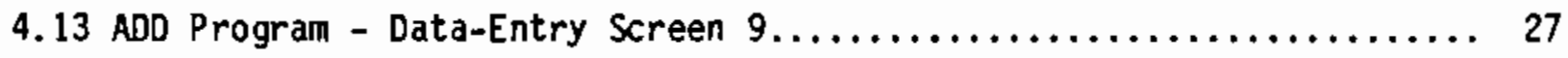

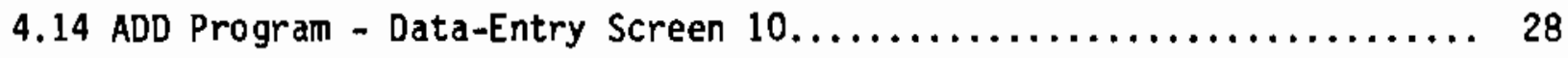

4.15 EDIT Program - Information Sel ection Menu................... 28

4.16 REPORT Program - Report Menu............................ 29

4.17 SEARCH Program - Search Menu............................ 29 
3.1 CEGEN FiTe Structure..................................... 7

3.2 Individual Office Data File Names......................... 10

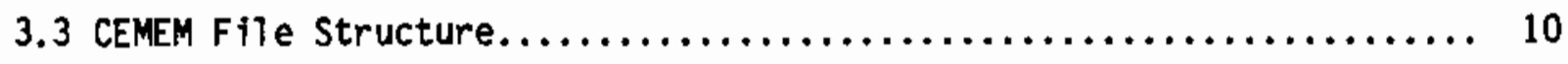

3.4 CEKEY fil e Structure.................................... 11

4.1 Executing the CEDATA Program............................... 12

4.2 Summary of Commands Useful for Data Entry,................. 15

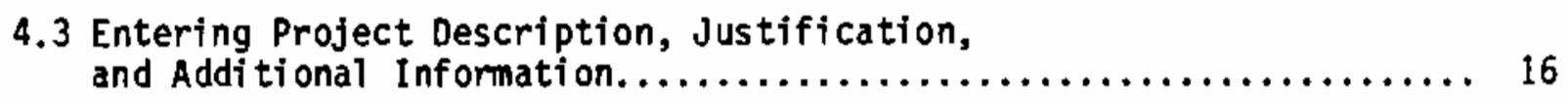

4.4 Field Names for Boolean Search Program...................... 20 
This User Manual describes the Conservation Project Data Base developed by the Pacific Northwest Laboratory for the Department of Energy's Office of Conservation (CE). The purpose of this data base is to provide a centralized storehouse of information on planned and ongoing projects funded by $C E$. The data base is a powerful analytical tool that will enable CE to quickly analyze the composition of their project portfollo. The data base uses dBase III a) on an IBM PC(D). Over 80 data items are stored for each project. A menudriven applications program was developed as an alternative to using standard dBase III commands. The menu-driven program prompts the user to add data, edit data, perform on-screen searches of the data base, sort the data base by any variable or combination of variables, or print hard-copy reports of various data items.

(a) dBase III is a trademark of Ashton-Tate, Culver City, Cal ifornia.

(b) IBM PC is a trademark of International Business Machines Corporation, Boca Raton, Florida. 


\subsection{INTRODUCTION}

This User Manual documents the development of the Conservation Project Data Base for DOE's Office of Conservation (CE). It is the culmination of an 8month effort that began in October 1984 with the conceptual design of the CE Project Data Sheet. The data sheet has undergone extensive modifications by a DOE working group of representatives from each of the Program Offices:

- Building Energy Research and DeveTopment

- Industrial Programs

- Vehicle and Engine R\&D

- Energy Systems Research

The final version of the data sheet is shown in Figure 1.1.

Once the final format of the data sheet was determined, each of the Offices was asked to distribute copies to its DOE Project Managers to gather information on all of the projects managed by them. This data was collected and entered into the CE Project Data Base. Computer-generated reports on all the projects in the data base were then distributed to the Project Managers to review and, if necessary, correct the information. Changes were incorporated into the data base as received by PNL.

The objective of this User Manual is to provide users of the CE Project Data Base with a basic understanding of the program operation and its capabilities. The manual presents an overview of the data base; descriptions of the main data files; a detailed discussion of the applications program that allows the user to add data, edit data, print reports, and perform on-screen searches; and a trouble-shooting guide in case something goes wrong. Also included are program listings and sample reports.

PNL selected dBase III as the data base management system for the CE Project Data Base because of its flexibility in sorting and reporting, and its large data storage capability. With dBase III the user can sort the data by any variable or combination of variables and report the results in any manner desired. The dBase III program allows 128 fields per record, which is adequate for the CE Project Data Base content. The dBase III program is compatible with the IBM PC, XT, or any IBM PC-compatible computer. The following are required:

- 256K bytes RAM memory

- Two 5-1/4 inch 360K byte diskette drives or one fixed disk drive and one diskette drive

- PC-DOS 2.0 (or a later version) operating system. 
1. Project title

2. Project identification
A. Program
B. Subprogram
C. Area
D. Key activity

3. DOE project asnager

A. Name

B. Phone ()$-$

4. Contractor's project manager

A. Name (Lat, Firat, MI)

B. Research organization

C. Business address: Street

city

D. Phone
$-$
State zip

5. Description

6. Jugtification

7. Program incerrelationships

c. Necessary for completion of anocher project

\section{E. Type of organization}


FIGURE 1.1

CONSERVATION PROJECT DATA SHEET

(CONT IRUED)

11. Energy gavings

\section{Fon}
A. Oil
B. Gas
c. Coal
D. Other
E. Electricity (A $34128 \mathrm{su} / \mathrm{k}$ wh
F. Eloctric loasea (8091 8tu/ kith saved)
G. Primary energy aot specified by kind
H. Net savings (sum of the above)
I. Not applicable

\section{$10^{12} \mathrm{Btw} /$ Year}
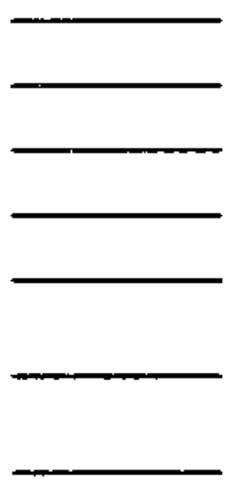

12. Assumptions

A. Per-unit annual gaviogs

B. Year 2010 morket (number of units)

C. Haximum potencial market penetration (7)

D. Market penetration surve

Yarar

Year $b$

Year c

13. Aceeleration poriod (number of years)

14. Other edergy-rolated benefits
A. Mulfiple fuel capebility

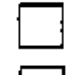
C. Energy scorage benefic
B. Alterative tuel bedefics
D. Electric load manageme benefic

15. Non-energy benefits
A. Technology leadership
B. Public heaith
B. Induatrial competitiveness
F. Environantal quality
C. National security
G. Reduced consumer costs
D. Sygtem reliabilicy
H. Employment

16. Projeet costs

A. DOE budgetary costs

Sunk through Ft 86 . . . .

FY $87 \ldots \ldots$

FY 88 ...........

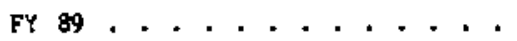

$\mathrm{FY} 90 \ldots . . . . .$.

FY $91 \ldots \ldots . . . \ldots$

Cumulative Fr 87

through comptetion .....

B. Privace sector contributions

Sunik through $\mathrm{F} 86$.....

Cumularive FY 97

inrough coopletion
17. Funding profile
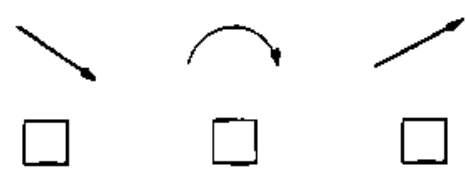

$\longrightarrow$

Other

18. Addirioual informetion 


\subsection{OVERVIEW OF CONSERVATION PROJECT DATA BASE}

PNL developed this computerized data base of information on all CE projects funded by the offices of:

- Building Energy Research \& Development

- Industrial Programs

- Vehicle and Engine R\&D

- Energy Systems Research

- Energy Conversion and Utilization Technology

- Electric Energy Systems

- Energy Storage

The data base contains the following items for each project:

- Project title

- Project identification

- DOE Project Manager

- Contractor's project manager

- Description

- Justification

- Program interrelationships

- Project category

- R\&D phase

- Technical keywords

- Energy savings

- Assumptions

- Acceleration period

- 0 ther energy-related benefits

- Non-energy benefits

- Project costs

- Funding profile

- Additional information 


\subsection{DATA FILES}

The entire CE Project Bata Base is stored on a hard disk and, in addition, each individual office's a data base is stored on a separate floppy disk. There are three separate data files for each 0ffice: a general file, a memo file, and a keyword file. The project descripions, justifications, and keywords are stored in separate files because they consist of long strings of textual information that is time-consuming to sort. The general file contains general project information plus data on project benefits and costs. The memo file contains the project descriptions, justifications, and any additional notes. The keyword file contains several categories of descriptive keywords about the projects. In addition to the three main data files, there are 6 utility files that serve as reference tables for the codes used in the project data files. The structure and contents of the utility files are listed in Appendix $D$. Each of the data files is discussed below.

\subsection{CEGEN}

The CEGEN file contains all of the general information about the CE projects stored in the data base. Table 3.1 lists the names, types, widths, and descriptions of the fields in the general file. Each office has an individual general file of its own. The file names are shown in Table 3.2.

\subsection{CEMEM}

The CEMEM file is a memo file that contafins the project descriptions and justifications as well as any additional information that may be stored about any of the projects. Table 3.3 lists the names, types, widths, and descriptions of the fields in the memo file. The individual office memo file names are shown in Table 3.2.

\subsection{CEKEY}

The CEKEY file contains descriptive technical keywords for each project. The keyword categories are: Disciplines, Materials, Techniques, Phenomena, Environment, and other. Each project can have up to three keywords in each of the six categories. Table 3.4 lists the names, types, widths and descriptions of the fields in the keyword file. The individual office keyword file names are show in Table 3.2 .

(a) There is no data base for the entire Office of Energy Systems Research. Instead, there are three separate data bases for the three program areas funded by this office: Energy Conversion and Utilization Technology, Electric Energy Systems, and Energy Storage. These three program areas are loosely referred to as "Offices" in this User Manual. 
TABLE 3.1. CEGEN File Structure

\begin{tabular}{|c|c|c|c|c|c|}
\hline Field & Name & Type. & Width & Decimals & Field Description \\
\hline 1 & PRJND & Nomeric & 4 & & Project Number \\
\hline 2 & PRG & Character & 5 & & Program \\
\hline 3 & SUBPRG & Character & 4 & & Subprogram \\
\hline 4 & AREA & Character & 4 & & Area \\
\hline 5 & KEYACT & Character & 55 & & Key Activity \\
\hline 6 & TITLE & Character & 60 & & Title \\
\hline 7 & DOEPM & Character & 25 & & DDE Project Manager \\
\hline 8 & DOEPH & Character & 12 & & DOE Project Manager's Phone \\
\hline 9 & CONPM & Character & 25 & & Contractor's Project Manager \\
\hline 10 & CONORG & Character & 40 & & Contractor's Organization \\
\hline 11 & CONSTR & Character & 35 & & Street Address \\
\hline 12 & CONCITY & Character & 20 & & City \\
\hline 13 & CONSTATE & Character & 2 & & State \\
\hline 14 & CONZIP & Character & 5 & & Zip Code \\
\hline 15 & CONPH & Character & 12 & & Contractor's Phone Number \\
\hline 16 & CONTYPE & Character & 1 & & Type of Contractor \\
\hline 17 & LAW & Character & 1 & & Mandated by Law $(Y / N)$ \\
\hline 18 & PRGSUP & Character & 1 & & Program Support (Y/N) \\
\hline 19 & OTHPRJ & Character & 1 & & $\begin{array}{l}\text { Necessary for Completion of } \\
\text { Other Project }(Y / N)\end{array}$ \\
\hline 20 & OTHNAM & Character & 55 & & Name of Other Project \\
\hline 21 & PRJCAT & Character & 2 & & Project Category \\
\hline 22 & PHASE1 & Character & 2 & & R\&D Phase at Start of FY87 \\
\hline 23 & PHASE2 & Character & 2 & & $\begin{array}{l}\text { R\&D Phase at Project Comple- } \\
\text { tion }\end{array}$ \\
\hline 24. & PR1 & Character & 1 & & $\begin{array}{l}\text { Profect Priority (Non-Discre- } \\
\text { tionary) }\end{array}$ \\
\hline
\end{tabular}


TABLE 3.1, CEGEN File Structure (Continued)

\begin{tabular}{|c|c|c|c|c|c|}
\hline Field & Name & Type & Width & Decimals & Field Description \\
\hline 25 & PR2 & Numeric & 2 & & $\begin{array}{l}\text { Project Priority (Discretion- } \\
\text { ary) }\end{array}$ \\
\hline 26 & PR3 & Numeric & 3 & & Project Priority (Overall) \\
\hline 27 & PR4 & Numeric & 2 & & Project Priority (Spare) \\
\hline 28 & OIL & Numeric & 6 & 1 & 011 Savings (Trillion Btu/yr) \\
\hline 29 & GAS & Numeric & 6 & 1 & Gas Savings (Trillion Btu/yr) \\
\hline 30 & COAL & Numeric & 6 & 1 & Coal Savings (Trillion Btu/yr) \\
\hline 31 & OTHFUEL & Numeric & 6 & 1 & $\begin{array}{l}\text { Other Fuel Savings (Trillion } \\
\text { Btu/yr) }\end{array}$ \\
\hline 32 & ELECT1 & Numeric & 6 & 1 & $\begin{array}{l}\text { Electrical Savings (Trillion } \\
\text { Btu/yr) }\end{array}$ \\
\hline 33 & ELECT2 & Numeric & 7 & 1 & $\begin{array}{l}\text { Electrical Losses (Trillion } \\
\text { Btu/yr) }\end{array}$ \\
\hline 34 & UNSPC & Numeric & 6 & 1 & $\begin{array}{l}\text { Unspecified Savings (Trillion } \\
\text { Btu/yr) }\end{array}$ \\
\hline 35 & NETSAV & Numeric & 8 & 1 & Net Savings (Trillion Btu/yr) \\
\hline 36 & ANNSAV & Character & 40 & & Per-Unit Annual Savings \\
\hline 37 & MARKET & Character & 10 & & Year 2010 Market \\
\hline 38 & MKTMAX & Numeric & 3 & & $\begin{array}{l}\text { Maximum Market Penetration } \\
\text { Potential }(\%)\end{array}$ \\
\hline 39 & MKTY1 & Character & 4 & & $\begin{array}{l}\text { Year when } 10 \% \text { of Maximum is } \\
\text { Reached }\end{array}$ \\
\hline 40 & MKTY2 & Character & 4 & & $\begin{array}{l}\text { Year When } 50 \% \text { of Maximum is } \\
\text { Reached }\end{array}$ \\
\hline 41 & МKTY3 & Character & 4 & & $\begin{array}{l}\text { Year When } 90 \% \text { of Maximum is } \\
\text { Reached }\end{array}$ \\
\hline 42 & ACCY & Character & 2 & & Acceleration Period (Years) \\
\hline 43 & MULTI & Character & 1 & & $\begin{array}{l}\text { Mul tiple Fuel Capability } \\
(Y / N)\end{array}$ \\
\hline
\end{tabular}




\begin{tabular}{|c|c|c|c|c|c|}
\hline Field & Name & Type & Width & Decimal s & Field Description \\
\hline 44 & ALTFUEL & Character & 1 & & $\begin{array}{l}\text { Alternative Fuel Capability } \\
(Y / N)\end{array}$ \\
\hline 45 & STOR & Character & 1 & & Energy Storage Benefit $(Y / N)$ \\
\hline 46 & ELOAD & Character & 1 & & $\begin{array}{l}\text { Electric Load Management } \\
\text { Benefit }(Y / N)\end{array}$ \\
\hline 47 & NE1 & Character & 2 & & Non-Energy Benefit \\
\hline 48 & NE2 & Character & 2 & & Non-Energy Benefit \\
\hline 49 & NE3 & Character & 2 & & Non-Energy Benefit \\
\hline 50 & NE4 & Character & 2 & & Non-Energy Benefit \\
\hline 51 & NE5 & Character & 2 & & Non-Energy Benefft \\
\hline 52 & SUNK & Numeric & 7 & 3 & DOE Sunk Costs \\
\hline 53 & FY87 & Nuneric & 6 & 3 & FY87 Budget \\
\hline 54 & FY88 & Nuneric & 6 & 3 & FY88 Budget \\
\hline 55 & FY89 & Numeric & 6 & 3 & FY89 Budget \\
\hline 56 & FY90 & Numeric & 6 & 3 & FY90 Budget \\
\hline 57 & FY91 & Numeric & 6 & 3 & FY91 Budget \\
\hline 58 & TOTAL & Numeric & 8 & 3 & $\begin{array}{l}\text { Cumul ative DOE Cost to Comple- } \\
\text { tion }\end{array}$ \\
\hline 59 & PSSUNK & Numeric & 6 & 3 & Private Sector Sunk Costs \\
\hline 60 & PSTOT & Numeric & 8 & 3 & $\begin{array}{l}\text { Cumulative Private Costs to } \\
\text { Completion }\end{array}$ \\
\hline 61 & FPROF & Character & 1 & & Funding Profile \\
\hline
\end{tabular}


TABLE 3.2. Individual Office Data File Names

\begin{tabular}{llll}
\multicolumn{1}{c}{ office } & $\begin{array}{c}\text { General File } \\
\text { Name }\end{array}$ & $\begin{array}{c}\text { Memo } \\
\text { File Name }\end{array}$ & $\begin{array}{c}\text { Keyword } \\
\text { File Name }\end{array}$ \\
\cline { 3 - 4 } $\begin{array}{l}\text { Building Energy Research } \\
\text { and Development }\end{array}$ & BCSGEN & BCSMEM & BCSKEY \\
$\begin{array}{l}\text { Energy Conversion and } \\
\text { Utilization Technol ogy }\end{array}$ & ECTGEN & ECTMEM & ECTKEY \\
Electric Energy Systems & EESGEN & EESMEM & EESKEY \\
Energy Storage & ESGEN & ESMEM & ESKEY \\
Industrial Programs & IPGEN & IPMEM & IPKEY \\
Vehicle and Engine R8D & TPGEN & TPMEM & TPKEY
\end{tabular}

TABLE 3.3. CEMEM File Structure

\begin{tabular}{|c|c|c|c|c|}
\hline Field & Name & Type & Width & Field Description \\
\hline 1 & PRG & Character & 5 & Program \\
\hline 2 & PRJNO & Numeric & 4 & Project Number \\
\hline 3 & PRJDES & Memo & 10 & Profect Description \\
\hline 4 & JUST & Meno & 10 & Project Justification \\
\hline 5 & NOTES & Meno & 10 & Additional Notes \\
\hline
\end{tabular}


TABLE 3.4. CEKEY File Structure

\begin{tabular}{|c|c|c|c|c|}
\hline Field & Name & Type & Width & Field Description \\
\hline $\begin{array}{r}1 \\
2 \\
3 \\
4 \\
5 \\
6 \\
7 \\
8 \\
9 \\
10 \\
11 \\
12 \\
13 \\
14 \\
15 \\
16 \\
17 \\
18 \\
19 \\
20\end{array}$ & $\begin{array}{l}\text { PRG } \\
\text { PRJN0 } \\
\text { DIS1 } \\
\text { DIS2 } \\
\text { DIS3 } \\
\text { MAT1 } \\
\text { MAT2 } \\
\text { MAT3 } \\
\text { TQ1 } \\
\text { TQ2 } \\
\text { TQ3 } \\
\text { PH1 } \\
\text { PH2 } \\
\text { PH3 } \\
\text { EN1 } \\
\text { EN2 } \\
\text { EN3 } \\
\text { OT1 } \\
\text { OT2 } \\
\text { OT3 }\end{array}$ & $\begin{array}{l}\text { Character } \\
\text { Numeric } \\
\text { Character } \\
\text { Character } \\
\text { Character } \\
\text { Character } \\
\text { Character } \\
\text { Character } \\
\text { Character } \\
\text { Character } \\
\text { Character } \\
\text { Character } \\
\text { Character } \\
\text { Character } \\
\text { Character } \\
\text { Character } \\
\text { Character } \\
\text { Character } \\
\text { Character } \\
\text { Character }\end{array}$ & $\begin{array}{r}5 \\
4 \\
30 \\
30 \\
30 \\
30 \\
30 \\
30 \\
30 \\
30 \\
30 \\
30 \\
30 \\
30 \\
30 \\
30 \\
30 \\
30 \\
30 \\
30\end{array}$ & $\begin{array}{l}\text { Program } \\
\text { Project Number } \\
\text { Disciplines } \\
\text { Discipl ines } \\
\text { Disciplines } \\
\text { Materials } \\
\text { Materials } \\
\text { Materials } \\
\text { Techni ques } \\
\text { Techni ques } \\
\text { Techni ques } \\
\text { Phenomena } \\
\text { Phenomena } \\
\text { Phenomena } \\
\text { Environment } \\
\text { Environment } \\
\text { Environment } \\
\text { Other } \\
\text { Other } \\
\text { Other }\end{array}$ \\
\hline
\end{tabular}




\subsection{APPLICATIONS PROGRAM}

An interactive, menu-driven program is provided to enter, edit, sort and report the data in the Conservation Project Data Base. The applications program has a modular design. Subroutines are called and executed from the main program (CEOATA) as shown in Figure 4.1. These subroutines are of three types: command files (file name extension .PRG), format files (file name extension .FMT), and report form files (file name extension .FRM). Comuand files consist of sets of instructions in dBase III programing language. Format files create custom screen formats for data entry or on-screen data display. Report form files provide a standard framework for reporting data base information. Each of the modules shown in Figure 4.1 is discussed in detail below. In addition, Appendix A contains program 1 istings for the command files and the screen format files.

\subsection{CEDATA}

The CEDATA program controls the execution of the appropriate subroutines based on the application selected from the on-screen menu. The four main applications that can be called from the CEDATA program are: (1) adding data for new projects to the data bases, (2) editing existing project data, (3) reporting project data, and (4) searching the data base for projects that meet user-specified criteria. In addition, a help program can be called which describes the functions of the major command programs and refers the user to the appropriate sections of the User Manual.

Table 4.1 lists the steps used to initiate the CEDATA program. These instructions are based on the following system configuration:

- Disk Drive $A$ is the default disk drive

- The Conservation Project Data Base and the applications program are stored on the hard disk

- dBase III is on the hard disk

\section{TABLE 4.1. Executing the CEDATA Program}

Step

1. Boot system with PC DOS.

2. Type D:, where $D$ represents the hard disk designator, to change the logged disk drive to the hard disk

3. Place the dBase III disk in Drive $A$

4. Type DBASE to enter the dBase III program

5. Remove the dBase III disk from Drive A

6. Type DO CEDATA

7. Press any key to go to the next screen
Screen Response

$A>$ (DOS prompt on Drive A)

$D>$ (DOS prompt on Hard Disk Drive)

- (dBase III dot command)

Conservation Project Data Base banner shown in Figure 4.2 appears

The applications menu shown in Figure 4.3 appears 


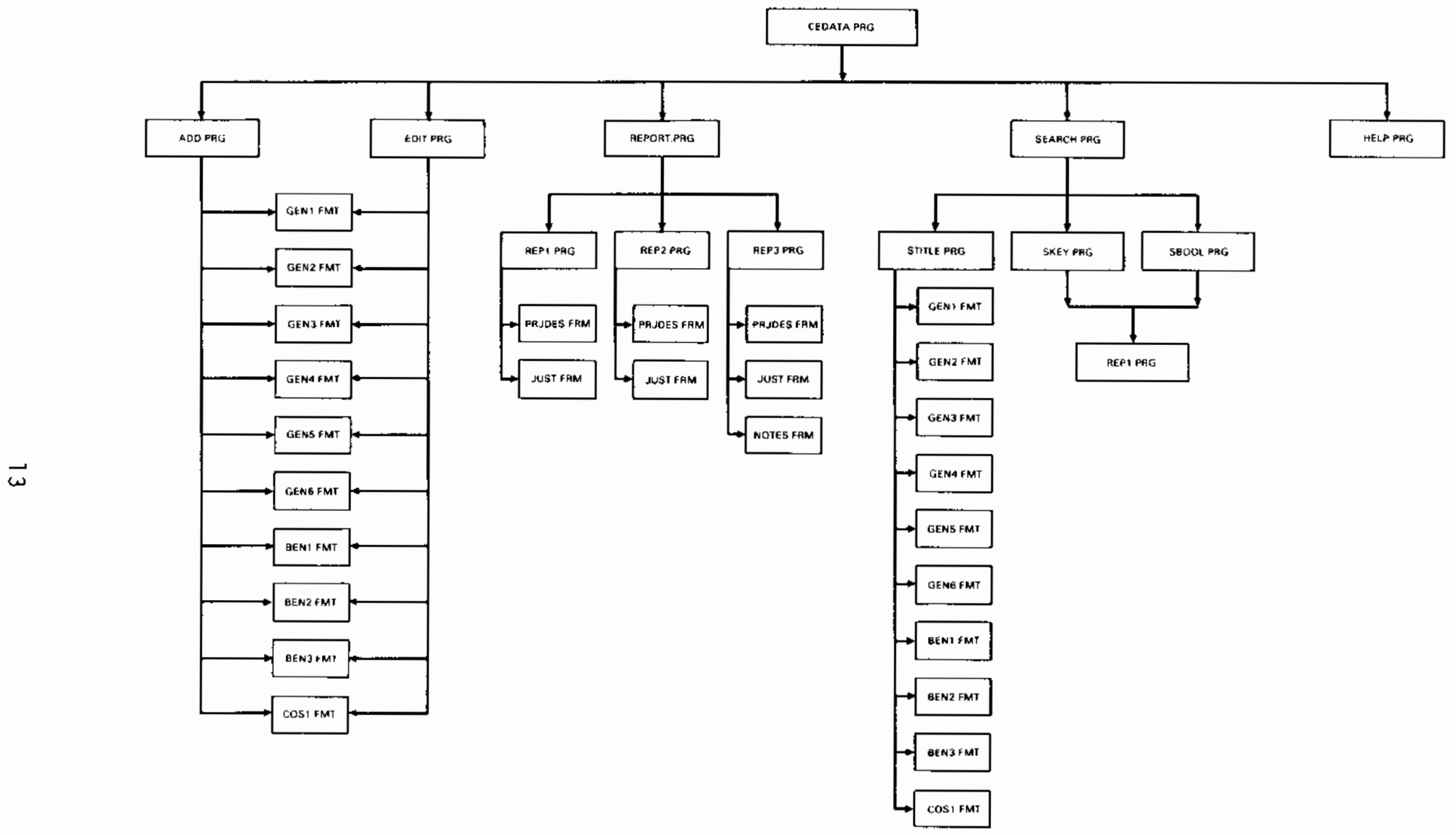

FIGUIIE 4.1. CE Data iase Program Structure 


\subsection{ADDING DATA}

The data entry program (ADD.PRG) allows the addition of information for a project that is not currently in the data base. The ADD program is executed when the first option is selected from the applications menu of the CEDATA program. Data entry is accomplished through formatted screens that are called from the ADD program. These screens are stored as the following separate files:

\begin{tabular}{|c|c|c|}
\hline File Name & Screen Number & Description \\
\hline GEN1.FMT & 1 & $\begin{array}{l}\text { Project title, fdentification, DOE project } \\
\text { manager, contractor }\end{array}$ \\
\hline GEN2.FMT & 2 & Program Interrelationships \\
\hline GEN3.FMT & 3 & Project Category \\
\hline GEN4.FMT & 4 & R\&D Phase \\
\hline GEN5.FMT & 5 & Keywords \\
\hline GEN6.FMT & 6 & Keywords (cont.) \\
\hline BEN1.FMT & 7 & Energy Savings \\
\hline BEN2.FMT & 8 & Energy Savings Assumptions \\
\hline BEN3.FMT & $\mathbf{g}$ & Non-Energy Benefits \\
\hline $\operatorname{COS1.FMT~}$ & 10 & Budgetary Information \\
\hline
\end{tabular}

The ADD program first asks the user to specify in which program area the project information is to be entered. The program area is selected by entering the associated number from the menu presented on the screen (Figure 4.4). The ADD program then presents ten formatted data-entry screens (Figures 4.5 through 4.14) in sequence for character and numeric data entry. Then, the user is asked to refer to the User Manual to enter the project description, justification and any project notes. After all the data for a given project is entered, the screen asks if data for another project is to be entered. If the user responds yes (Y), the program will again present the menu for selecting the progran area. If the user responds no $(N)$, the progran returns to the applications menu in the CEDATA program (Figure 4.3). The following sections provide instructions for entering character/numeric data and memo data.

\subsubsection{Entering Character and Numeric Data}

All items, with the exception of the project description, justification, and additinal information (Items 5, 6, and 18 on the Conservation Project Data Sheet, Figure 1.1) are stored in character or numeric fields. All numeric and character data is stored in the data base in capital letters. Thus, before entering data, press the "Caps Lock" key. To enter data, simply type the requested information in the highlighted spaces provided on the formatted screens. If information is not entered in a given space, the data base will automatically store zeroes in numeric fields and blanks in character fields. 
If the data completely fills the space provided, the cursor will automatically jump to the next item. If the data does not completely fill the space, use the "RETURN" key to move to the next item. The arrows on the right of the keyboard can be used to position the cursor at the desired location. When you are finished entering data on a particular screen, press "PgDn" to go to the next screen. Once you have exited a screen, you will not be able to go back to it while in the ADD program. If you want to change data items that you have entered on a previous screen, refer to Section 4.3 of this User Manual.

A space is not provided for entering the net energy savings. The program automatically calculates this total and displays it on the screen. The program al so checks that the cumulative budgetary costs from FY87 through completion are greater than or equal to the sum of the entries for FY87 through FY91. If the cumulative figure is less than this sum, an error message will appear on the screen and the user will be given the opportunity to re-enter the data. The corrected data is simply typed over the top of the current data (with "INSERT" in the OFF mode).

Table 4.2 provides a list of commands that may be helpful in entering character and numeric data.

TABLE 4.2. Summary of Commands Useful for Data Entry

"Ctrl/Y" Deletes all data to the right of the cursor in a given field

"Del" or "Ctrl G" Deletes the character at the cursor position

"RETURN" Moves cursor to the next data item

"PgDn" or "Esc" Moves to the next formatted screen

"Ins" When ON, any text that is typed is inserted at the cursor position. When OFF, any text is typed over the top of existing text. ON/OFF mode is displayed in upper right-hand corner of screen.

4.2.2 Entering the Project Description, Justification and Additional InformaEion

The project description, justification and additional information are stored in memo fields. The dBase III text editor is used to enter data into memo fields. After all of the character and numeric data are entered for a project, the screen displays the following:

To add Project Description, Justification or Notes, refer to Section 4.2.2 of the User Manual.

Press any key to continue...

After a key is pressed, the memo data file structure is displayed on the screen as follows: 


$\begin{array}{ll}\text { Record No. } & \text { NNN } \\ \text { PRG } & \text { XXX } \\ \text { PRJNO } & \text { NNN } \\ \text { PRJDES } & \text { memo } \\ \text { JUST } & \text { meno } \\ \text { NOTES } & \text { memo }\end{array}$

To enter information in these fields refer to the instructions in Table 4.3.

\section{TABLE 4.3. Entering Project Description, Justification, and Addi tiona 1 Information}

1. Position the cursor on the field in which data is to be entered: PRJDES = Project Description, JUST = Justification, NDTES = Additiona1 Information.

2. Press "Ctrl/PgDn" to enter the memo field. (A blank screen will be provided.)

3. Set the "Caps Lock" to OFF.

4. Type the text. (Note: Do not press "RETURN" at the end of a line and do not use hyphens to divide words at the end of the line. The text automatically wraps around to the next line. The format in which it appears on the screen is not necessarily the format in which it wi1l appear when printed.)

5. Refer to the dBase III User Manual, Page 4-69, for special function keys that are useful in the text editor mode.

6. After the information has been entered, press "Ctrl/End" to exit the memo fie?d.

7. Repeat the preceding steps to enter data in each of the memo fields.

\subsection{EDITING DATA}

The data edit program (EDIT.PRG) allows the modification of project information that is already stored in the data base. The EDIT program is executed when the second option is selected from the applications menu of the CEDATA program. The EDIT program asks the user to enter the title of the project that is to be edited. The program searches the data base for the title.

If the title is not found, the screen displays:

"TITLE THAT WAS ENTERED NOT FDUND"

Would you like to enter another titie? $(\mathrm{Y} / \mathrm{N})$ : 
This indicates that either the title was entered incorrectly, or that the project is not currentiy in the data base. If the user responds yes ( $Y$ ) to the preceding question, the title can be re-entered. A no (N) response returns the user to the CEDATA applications menu.

If the title is found, the user is presented with another menu (Figure 4.15) from which he/she can elect to edit all data for the project (Option 11), or to edit a given data set (Options 1 through 10). Selecting Option 11 wili cause each of the formatted data screens to be presented sequentialiy, whereas the other options only display the pertinent data screen(s). The screens display the information that is currently in the data base for the project title that was entered. To make corrections, the new data is simply typed over the existing data, with "INSERT" in the OFF mode.

After a screen is edited, "PgDn" will call up the next formatted screen if Option 11 selected, or the user will be asked whether he/she would like to edit other information for this project. A yes $(Y)$ response returns the user to the menu to select the type of information to be edfted. If no (N), the user is then asked if he/she would like to edit data for another project. A yes (Y) response returns the user to the beginning of the EDIT program and asks for the title of the project to edit. A no $(N)$ response returns the user to the applications menu in the CEDATA program.

\subsection{PRINTING REPORTS}

The report program (REPORT.PRG) currently provides three reporting formats: (1) a project description sheet such as the one used in the Energy Conservation Multi-Year Plan FY87-FY91, (2) a brief project description including only items $1,2,3,5,6$, and 16 from the Conservation Project Data Sheet (Figure 1.1), and (3) an expanded project report of all the numeric and character data in the main data base. A sample of each of these types of reports is included in Appendix B.

When REPORT.PRG is called from the CEDATA program, the first screen displays the report menu (Figure 4.16) and asks the user to specify which of the three types of reports is to be printed. Once the type of report is selected, the next menu provides the option to print reports for: (1) al1 projects in the data base, (2) all projects in a selected progran area, or (3) a single project. If the first option is selected, no further information needs to be entered. The reports will start to print automatically. If the second option is selected, the screen displays a menu of the program areas (as in Figure 4.4) and the user is asked to select one. If option 3 is selected, the screen prompts the user to enter the title of the project to be reported.

The next screen prompts the user to turn on the printer, position the paper to the top of the page, and initialize the printer. This ensures that the printer and the REPORT program both recognize the first line of print as line 1. Failure to initialize the printer may cause printing of a subsequent page to begin in the middle of that page, rather than at the top.

In addition to the main report program (REPORT.PRG), there are three subroutines (REP1.PRG, REP2.PRG and REP3.PRG) that contain the program instructions for the three customized reports. Whereas REPORT is executed from the CEDATA program, REP1, REP2, and REP3 are automatically executed by the REPORT program as needed. To print information from the memo fields (project 
description, justification, or additional information), the following custom report programs are called from REP1, REP2, or REP3:

PRJDES.FRM - project description

JUST.FRM - Justification

NOTES.FRM - additional information

\subsection{ON-SCREEN SEARCH}

The on-screen search progran (SEARCH.PRG) is executed when option 4 is selected from the applications menu of the CEDATA program. SEARCH allows the user to search the data base for a given project title, for a combination of keywords, or for a combination of field constraints combined in a Boolean expression. Each of these options is discussed in more detall in the following sections. The search menu displaying the search options is shown in Figure 4.17 .

\subsubsection{Title Search}

The title search program (STITLE.PRG) is called from the SEARCH program when the user selects option 1 from the search menu. The user is first asked to enter the title of the project whtch is the object of the search. If the title is not found, the user is given the option to enter another title, return to the search menu, or return to the applications menu. If the title is found, a menu is provided which allows the user to elect to display all or selected information for that project on the screen. Project data is displayed on the same formatted screens used in the data entry and data edit programs. After viewing the data, press "Pgon". The user can then elect to: (1) display additional information for the project, (2) search for another project title, (3) return to the search menu, or (4) return to the applications menu.

\subsubsection{Keyword Search}

The keyword search program (SKEY.PRG) is executed when option 2 is selected from the search menu. A formatted screen is provided in which the user can enter up to six keywords. The keywords are entered along with a keyword code which indicates the type of keyword (i.e., discipline, material, technique, phenomenon, environment, or other). A list of keyword codes is provided on the screen. Keywords may be all of one type or all different types. The program automatically searches the keyword data base (CEKEY.DBF) for projects that list the keyword combination specified by the user. The screen witl display the number of projects that list the specified keywords and the percentage of the total number of projects in the data base that this represents.

For the projects that list the specified keywords, the user can elect to: (1) display the tities on the screen, (2) print the titles, or (3) print project description sheets for each of the projects. Alternatively, the user can elect to return to the search menu or the applications menu at this point.

\subsubsection{Boolean Search}

The Boolean search program (SBOOL.PRG) is executed when option 3 is selected from the search menu. This program allows the user to sort the data base on a combination of up to six field constraints. The following example, which has four field constraints, will be used to 117 ustrate the use of the Boolean search program: 
All projects mandated by 1 aw that are in the transportation program or the industry program and that will save more than 100 trillion Btu of oil annually.

The first screen in the Boolean search program prompts the user to enter up to six field name/field type/operator/data constraints. The screen is formatted for ease of data entry. The field name is entered first followed by an " $N$ " or a " $C$ " to indicate whether it is a numeric or character field, respectively. A list of the field names that can be used with the Boolean search option is provided in Table 4.4 by field type. Next, the desired relational operator is entered. The equal to $(=)$ and not equal to (\#) operators can be used with character or numeric data. The greater than (>), less than $(<)$, greater than or equal to $(>=)$, and less than or equal to $(<=)$ operators can only be used with numeric fields. Finally, the numeric or character data that is the object of the search is entered under the data column. Press "RETURN" to move to the next screen position. When you have entered all the constraints for the search, press "PgDn".

EXAMPLE:

$\begin{array}{lccc}\text { FIELD } & & & \\ \text { NAME } & \text { TYPE } & \text { OP } & \text { SEARCH DATA } \\ \text { LAW } & \mathrm{C} & = & \text { Y } \\ \text { PRG } & \mathrm{C} & = & \text { TP } \\ \text { PRG } & \mathrm{C} & = & \text { IP } \\ \text { OIL } & \text { N } & > & 100\end{array}$

The next screen displays the constraints that have been entered. Each of these is assigned a letter, beginning with $A$. The user is then asked to combine the constraints into a Boolean expression for the search, using the logical operators $A N D$ and $O R$ and parentheses as needed for grouping.

\section{EXAMPLE:}

$$
\begin{array}{ll}
A: & L A W=' Y^{\prime} \\
B: & P R G=1 T P^{\prime} \\
C: & P R G=I^{\prime} P^{\prime} \\
D: & O I L>100
\end{array}
$$

USE THE CODES ON THE RIGHT TO CODE LOGIC OPERATOR WRITE A BOOLEAN EXPRESSION (e.g., $(A+8) \star(C+D)$ represents $(A$ and $B)$ or $(C$ and $D)$

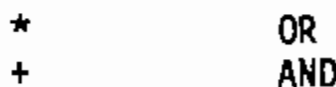

User Types: $\quad A+(B \star C)+D$

Program displays the following expression:

EXPRESSION: $L A W=' Y$ '.AND. (PRG $={ }^{\prime} T P^{\prime}=$. OR. $\left.P R G=' I P '\right) \cdot A N O .0 I L>100$

Press any key to continue...

The program then searches the data base for projects that meet the specified constraints. It sums the number of projects and the FY87 budgets of the projects that meet the constraints and displays this information on the screen along with the percentages of the total number of projects and project 
FIELD NAME

Character

Fields:

\section{PRG \\ SL8PRG \\ AREA \\ DOEPM \\ CONPM \\ CONORG \\ CONCITY \\ CONSTATE \\ CONTYPE \\ LAW \\ PRGSUP \\ OTHPRJ \\ PRJCAT \\ PHASE1 \\ PHASE2 \\ MULTI \\ ALTFUEL \\ STOR \\ ELOAD}

NE1-NE5

FPROF

Numeric

Fields:

OIL

GAS

COAL

DTHFUEL

ELECT1

ELECT2

UNSPC

NETSAY

MKTMAX

SUNK

FY87

FY88

FY89

FY90

FY91

TOTAL

PSSUNK

PSTOT

DESCRIPTION

F IELD

LENGTH

DECIMALS

$\begin{array}{lr}\text { Program } & 5 \\ \text { Subprogran } & 4 \\ \text { Area } & 4 \\ \text { DoE Project Manager } & 25 \\ \text { Contractor's Project Manager } & 25 \\ \text { Research Organization } & 40 \\ \text { Contractor's City } & 20 \\ \text { Contractor's State } & 2 \\ \text { Type of Organization } & 1 \\ \text { Mandated by Law? (Y/N) } & 1 \\ \text { Program Support? (Y/N) } & 1 \\ \text { Necessary for Completion of } & \\ \text { Other Project? (Y/N) } & 1 \\ \text { Project Category } & 1 \\ \text { Phase at Start of FY87 } & 2 \\ \text { Phase at Program Completion } & 2 \\ \text { Multi-Fuel Capabil Ity } & 1 \\ \text { Alternative Fuel Benefits } & 1 \\ \text { Energy Storage Benefit } & 1 \\ \text { Electric Load Management } & \\ \text { Benefit } & 1 \\ \text { Non-Energy Benefits } & 2 \\ \text { Funding Profile } & 1\end{array}$

Annual Oil Savings

Annual Gas Savings

Annual Coal Savings

Annual Savings other Fuels

Annua T Electricity Savings

Annual Electric Losses

Annual Savings-Unspecified

Annual Net Energy Savings

Maximum Potential Market Penetration

DOE Sunk Costs thru FY86

DOE FY87 Budgetary Costs

DOE FY88 Budgetary Costs

DOE FY89 Budgetary Costs

DOE FY90 Budgetary Costs

D0E FY91 Budgetary Costs

DOE Cumulative Costs FY87 thru Completion

Private Sector Sunk Costs thru FY86

Private Sector Cumulative Costs thru Completion
25

40

2

1

1

1
1
2
2
1
1
1
1
2
1 
budgets that it represents.

EXAMPLE: 2 PROJECT(S), WITH A CUMULATIVE BUDGET OF \$8.100 MEET THE FOLLOWING CRITERIA:

$L A W=' Y ' \cdot A N D \cdot(P R G=' T P ', O R . P R G=' I P ') \cdot A N D . O I L>100$

THIS REPRESENTS:

1. $1.40 \%$ OF THE 143 CONSERVATION PROJECTS

2. $0.02 \%$ OF THE TOTAL BUDGET

Press any key to continue...

For the projects that meet the constraints, the user can elect to: display the titles on the display the titles on the screen, (2) print the titles, or (3) print project description sheets for each of the projects. The user can elect to return to the search menu or the applications menu at this point.

\subsection{HELP}

The help progran (HELP.PRG) is executed when the user selects option 5 from the applications menu in the CEDATA program. In the HELP program, the user is asked to select the application with which he/she would ilike help. A brief paragraph describing the application is shown on the screen and the appropriate section in the User Manual is indicated.

\subsection{EXITING THE APPLICATIONS PROGRAM}

The user can exit the applications program by selecting option 6 from the CEDATA applications menu. This option closes all open files and returns the user to the DOS operating system.

At this point, backup copies of the data bases should be made to protect against loss of any new information that has been entered or any alterations that have been made. Backup can be accomplished from the DOS operating system with the following commands:

To backup a single file:

COPY d1:filename. DBF d2:filename. DBF

To backup aTl data base files:

COPY $d 1: \star . D B F d 2:$

To backup alt program files:

COPY $d 1:{ }^{\star}$. PRG $d 2$ :

Where $\mathrm{d} 1$ = source drive designation and $\mathrm{d} 2$ = destination drive designation. 
* CONSERVATION PROJeCt data baSe *

* OFFICE OF CONSERVATION *

* U. S. DEPARTMENT OF ENERGY *

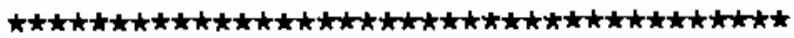

This data base contains descriptive information on each of the projects currently being conducted under the Office of Conservation, U.S. Department of Energy.

Refer to the User Manual for directions on how to use the data base.

Press any key to continue...

FIGURE 4.2. Conservation Project Data Base Banner

* CONSERVATION PROJECT DATA BASE **

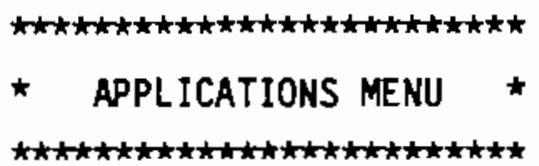

(1) ENTER DATA

(2) PRINT REPORT(S)

(3) EDIT

(4) ON-SCREEN SEARCH

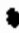

(5) HELP

(6) STOP

PLEASE SELECT A NUMBER: 0

FIGURE 4.3. CEDATA Program Applications Menu 
Add information for which program?
(1) BUILDINGS AND COMMUNITY SYSTEMS
(2) TRANSPORTATION
(3) INDUSTRY PROGRAM
(4) ENERGY STORAGE
(5) ELECTRIC ENERGY SYSTEMS
(6) ENERGY CONYERSION AND UTILIZATION TECHNOLOGY

PLEASE SELECT A NUMBER: 0

FIGURE 4.4. ADD Program - Program Selection Menu

1. Project Title

2. Project Identification
A. Program: $\mathbf{X X X}$
B. Subprogram:
C. Area:
D. Key Activity:

3. DOE Project Manager
A. Name:
B. Phone:

4. Contractor's Project Manager

A. Nane (Last, First, MI)

B. Research Organization:

C. Street Address:

City:

State: Zipcode:

D. Phone:

E. Type of Organization:

1 = Private Industry

5 = State or Local Government

2 = DOE Laboratory

$3=$ Other Federal Organization

$4=$ University

FIGURE 4.5. ADD Program - Data-Entry Screen 1 


\section{PROJECT TITLE: $\quad X X X X X$}

\section{PRDGRAM INTERRELATIONSHIPS}

A. Mandated Project $(Y / N)$ :

B. Progran Support $(Y / N)$ :

C. Necessary for Completion of Another Project $(Y / N)$ :

If yes, enter tftle of dependent project:

FIGURE 4.6. ADD Program - Data-Entry Screen 2

\section{PROJECT TITLE: $X X X X X$}

\section{PROJECT CATEGORY $=$}

\section{Category Codes:}

$1=$ Technot ogy R\&D

2 = Technology Assessment/Feasibil ity Study

$3=$ Heal th Effects and Safety Research

4 = Technical Support for Rule-Making

$5=$ Program and Pol icy Planning and Evaluation

6 = Energy and Economic Data Development or Analysis

7 = Mathematical Model Development

8 = Consumer Information on Energy Efficiency (General Public)

$9=$ Technology Transfer/Research Publications (Technical Community)

$10=$ Other

FIGURE 4.7. ADD Program - Data-Entry Screen 3 
Project Title: $x \times x \times x$

\section{R\&D PHASE}
A. Phase at Start of FY 1987:
B. Phase at Project Completion:

Phase codes are defined as follows:

1 Generic Research

2a Explore Product/Process Innovation and Concepts

2b Documentation and Theoretical Assessment of System Elements

2c Laboratory Testing and Evaluation of System Elements

3a System Engineering Design and Analysis

3b Detailed Engineering-Scale Design

4a Design Pilot-Scale Prototype

$4 b$ Build and Test Pilot-Scale Prototype

4c Evaluate Pilot-Scale Test Results

4d Design Ful1-Scale Proof-of-Principle Unit

4e Build and Test Full-Scale Proof-of-Principle Unit

4f Evaluate Full-Scale Proof-of-Principle Test Results

5 Demonstration Testing

6 Commercialization, Production and Operation

FIGURE 4.8. ADD Program - Data-Entry Screen 4

10. TECHNICAL KEYNORDS

1.
A. Disciplines

2.

3.

1.

B. Materials

2.

3.

1.

C. Techniques

2.

3.

1.

D. Phenomena

2.

3.

FIGURE 4.9. ADD Program - Data-Entry Screen 5 
10. TECHNICAL KEYMORDS (continued)

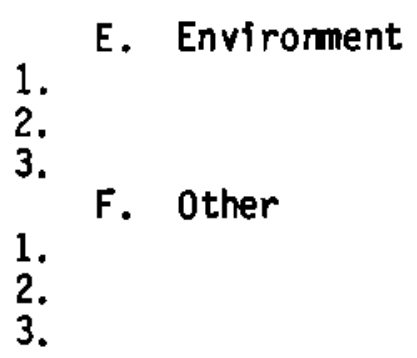

FIGURE 4.10. ADD Program - Data-Entry Screen 6

11. ENERGY SAYINGS

Form

Year 2010

(Trillion Btu/Year)

A. $0 i 1$

B. Gas

C. Coar

D. Other

E. Electricity at $3412 \mathrm{Btu} / \mathrm{kWh}$ saved

F. Electrical Losses at $8091 \mathrm{Btu} / \mathrm{kWh}$

G. Primary Energy Not Specified by Kind

H. Net Savings (sum of the above)

FIGURE 4.11. ADD Program - Data-Entry Screen 7 
12. ASSUMPTIONS FOR ENERGY SAVINGS
A. Per-Unit Annual Savings:
B. Year 2010 Market (Number of Units):
C. Maximum Potential Market Penetration (\%):
D. Market Penetration Curve:

$$
\begin{aligned}
& \text { Year a: } \\
& \text { Year b: } \\
& \text { Year c: }
\end{aligned}
$$

13. ACCELERATION PERIOD (number of years):

14. OTHER ENERGY-RELATED BENEFITS
A. Multiple Fuel Capability (Y/N):
B. Alternative Fuel Benefits $(Y / N)$ :
C. Energy Storage Benefit $(Y / N)$ :
D. Electric Load Management Benefit $(Y / N)$ :

FIGURE 4.12. ADD Program - Data-Entry Screen 8

\section{NON-ENERGY BENEFITS}

Benefits are prioritized on a scale of 0 to 5 . A score of 5 indicates a major national benefit and a score of 0 indicates no significant or known effect.

ENTER THE CODE FROM THE LIST ON THE RIGHT FOR UP TO FIVE NON-ENERGY BENEF ITS
$5=$
$\mathrm{TL}$ (Technology Leadership)
IC (Industrial Competitiveness)
$4=$
NS (National Security)
$3=$
SR (System Reliability)
$2=$
PH (Public Health)
EQ (Envirommental Qual ity)
$1=$
CC (Reduced Consumer Costs)
EM (Increased Employment)

FIGURE 4.13. ADD Program - Data-Entry Screen 9 
16. PROJECT COSTS

A. DOE Budgetary Costs

\section{\$Millions}

- Sunk through FY 1986:

- FY 1987:

- FY 1988:

- FY 1989:

- FY 1990:

- FY 1991:

- Cunulative FY87 thru Completion:

B. Private Sector Contributions

- Sunk through FY 1986: .

- Cumulative FY 1987 thru Completion:

17. FUNDING PROFILE: (Over Planning Horizon)

1 = Decreasing, 2 = Peaking, $3=$ Increasing, $4=$ Level, $5=$ Variable

FIGURE 4.14. ADD Program - Data-Entry Screen 10

SELECT TYPE OF INFORMATION TO EDIT FROM FOLLOWING LIST:

(1) Project Tit]e/Project ID/DOE Contact/Contractor

(2) Program Interrelationships

(3) Project Category

(4) R\&D Phase

(5) Technical Keywords

(6) Energy Savings

(7) Energy Savings Assumptions/AcceTeration Period/0ther Benefits

(8) Non-Energy Benefits

(9) Project Costs

(10) Project Description/Justification

(11) All Information

PLEASE SELECT A NUMBER: 0

FIGURE 4.15. EDIT Program - Information Sel ection Menu 
* CONSERVATION PROJECT DATA BASE $\star \star$

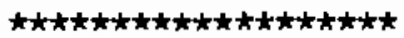

* REPORT MENU *

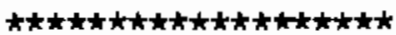

(1) PRINT STANDARD PROJECT REPORT

(2) PRINT BRIEF PROJECT REPORT

(3) PRINT EXPANDED PROJECT REPORT

(4) RETURN TO MAIN MENU

PLEASE SELECT A NUMBER: 0

FIGURE 4.16. REPORT Program - Report Menu

* CONSERVATION PROJECT DATA BASE **

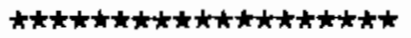

* SEARCH MENU *

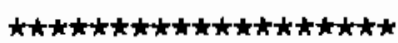

(1) TITLE SEARCH

(2) KEYWORD SEARCH

(3) BOOLEAN SEARCH

(4) RETURN TO MAIN MENU

PLEASE SELECT A NUMBER: 0

FIGURE 4.17. SEARCH Program - Search Menu 
APPENDIX A: PROGRAM IIISTINGS

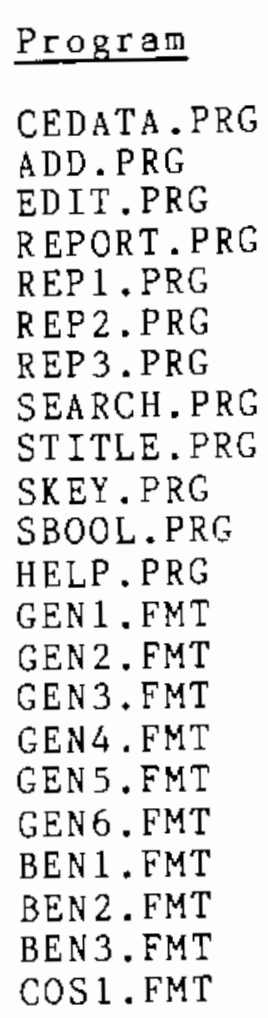

Page

A. 1

A. 3

A. 7

A. 13

A. 17

A. 23

A. 25

A. 31

A. 33

A. 37

A. 41

A. 45

A. 47

A. 49

A. 51

A. 53

A. 55

A. 57

A. 59

A. 61

A. 63

A. 65 


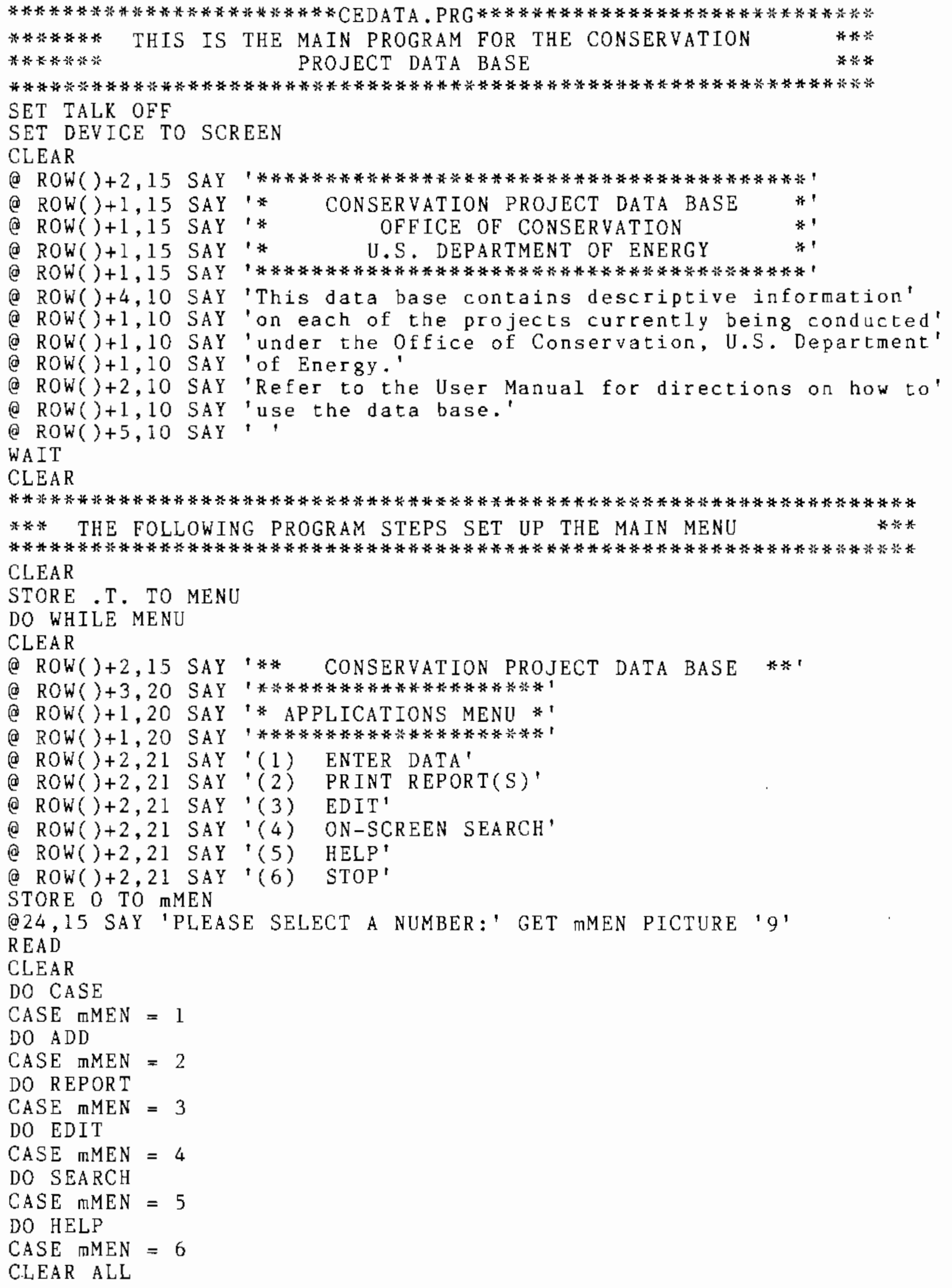


CASE $\mathrm{mMEN}=7$

STORE .F. TO MENU

ENDCASE

ENDDO

RELEASE ALL

RETURN 


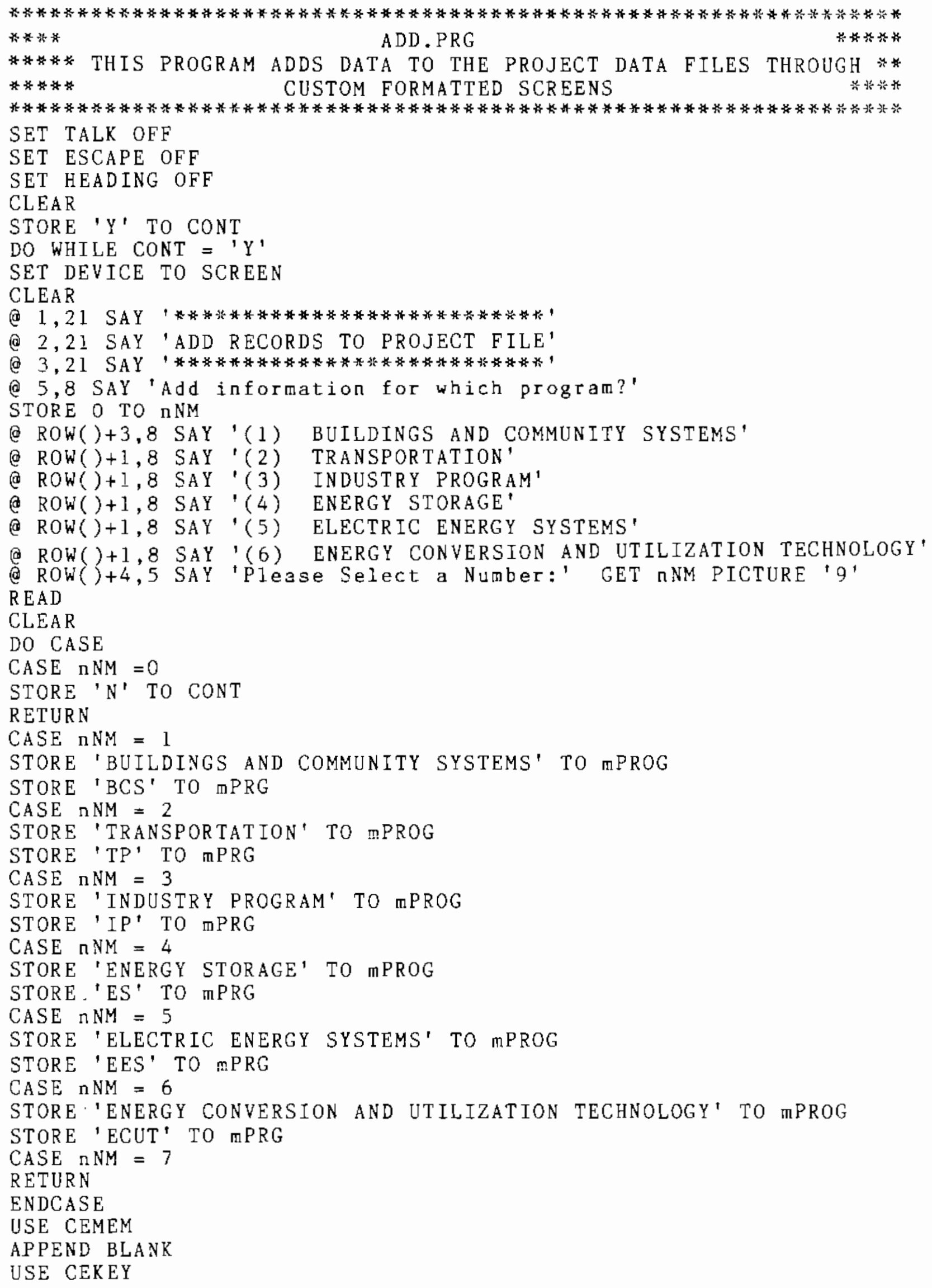




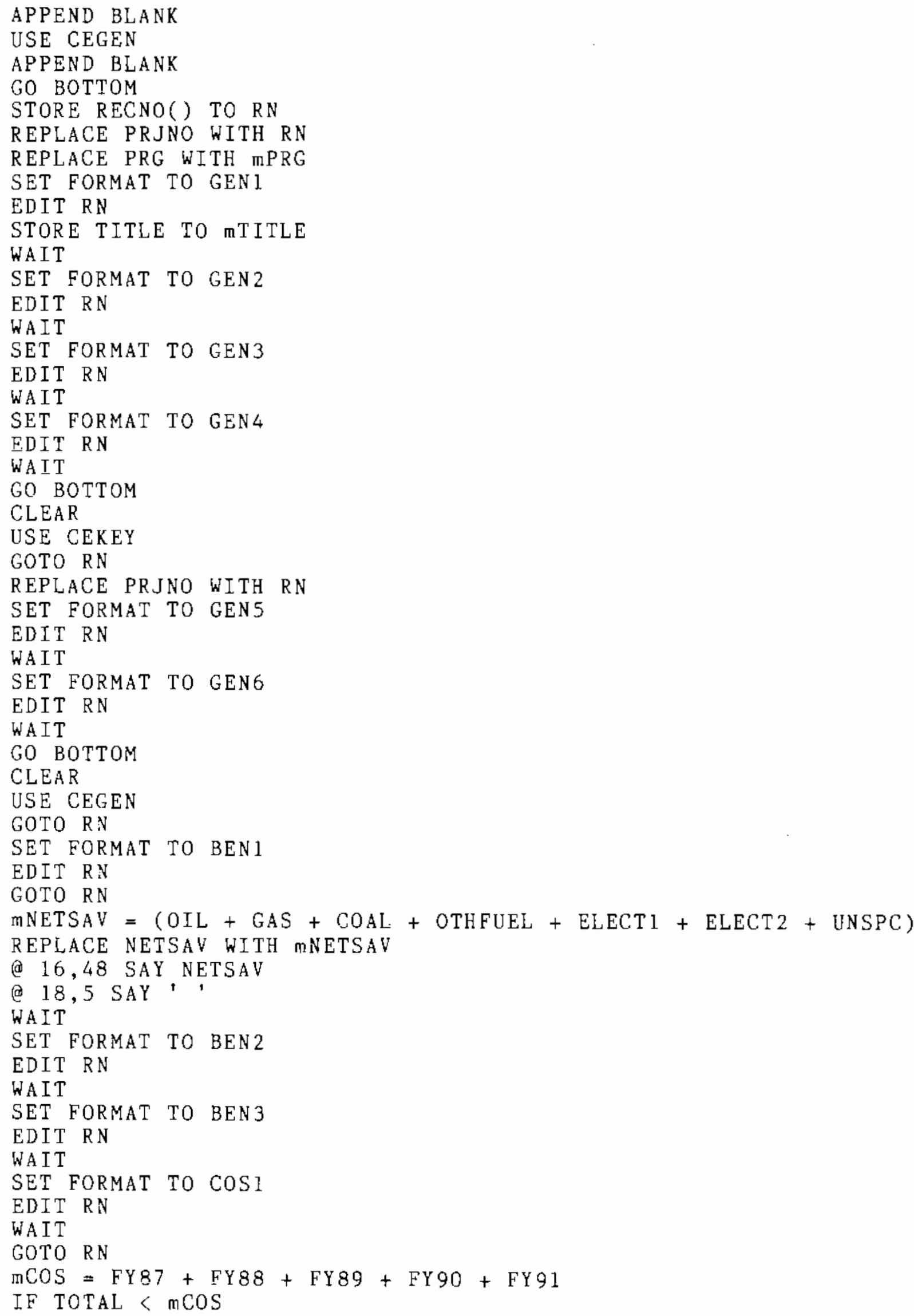




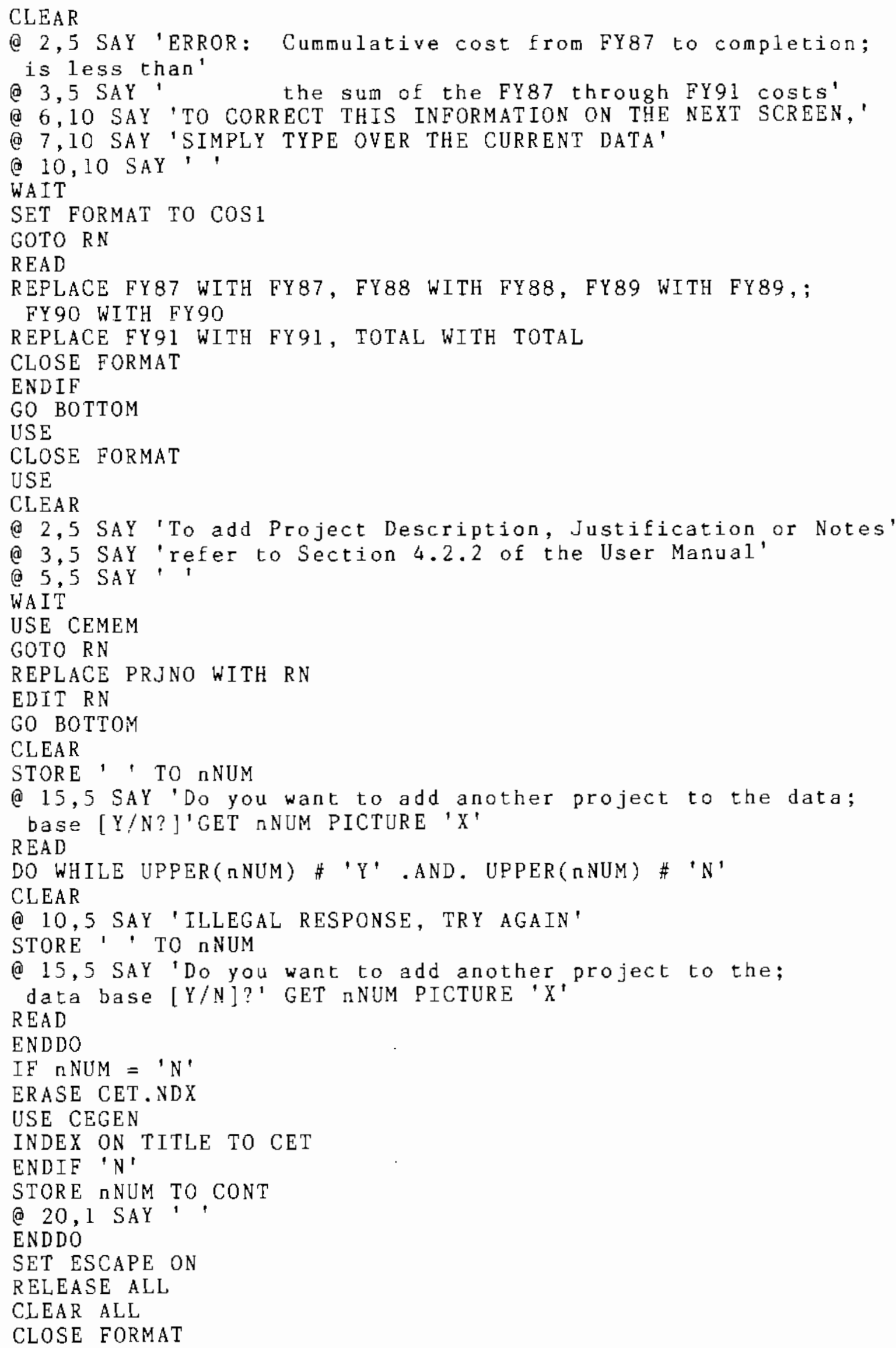


RETURN

A. 6 
*** PROGRAM ALLOWS DATA TO BE EDITTED IN THE SELECTED FILE

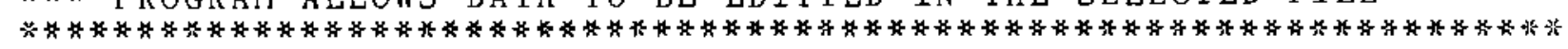

CLEAR ALL

SET TALK OFF

CLEAR

STORE.T. TO ED

DO WHILE ED

CLEAR

STORE '

to mTITLE

(a) 7,15 SAY ' ENTER TITLE OF PROJECT TO EDIT: '

@ 9,10 GET mTITLE

READ

USE CEGEN INDEX CET

DO WHILE . NOT. EOF()

LOCATE FOR TITLE $=$ UPPER(mTITLE)

IF $\operatorname{EOF}()$

CLEAR

@ 2,5 SAY 'TITLE NOT FOUND'

STORE ' $Y$ ' TO ANS

(d 3,5 SAY 'Would you like to enter another title?;

$[Y / N]: '$ GET ANS

READ

IF UPPER(ANS) $=$ ' $Y$ '

LOOP

ELSE

STORE, F. TO ED

STORE .T. TO MENU

RETURN

ENDIF ANS

ENDIF EOF

STORE RECNOC) TO R

CLEAR

(a ROW( $+1,5$ SAY'TO EDIT ANY OF THE DATA ITEMS SIMPLY TYPE OVER; THE'

(d ROW( ) +1,5 SAY 'EXISTING INFORMATION. PRESS 〈RETURN〉 TO MOVE TO; THE NEXT'

(a) ROW( $)+1,5$ SAY 'ITEM. AFTER CHANGES ARE MADE, PRESS 〈PgDn〉.'

(a) ROW ( ) +5,5 SAY'

WAIT

STORE .T. TO TYPE

DO WHILE TYPE

CLEAR

STORE O TO TYP

@ 1,15 SAY 'SELECT TYPE OF INFORMATION TO EDIT FROM FOLLOWING; LIST :

@ 3,5 SAY '(1) Project Title/Project ID/DOE Contact; /Contractor'

(a 4,5 SAY '(2) Program Interrelationships'

(a) 5,5 SAY '(3) Project Category'

(d) 6,5 SAY '(4) R\&D Phase'

@ $7,5 \mathrm{SAY}^{\prime}$ (5) Technical Keywords'

@ 8,5 SAY '(6) Energy Savings'

(a) 9,5 SAY '(7) Energy Savings Assumptions/Acceleration; 


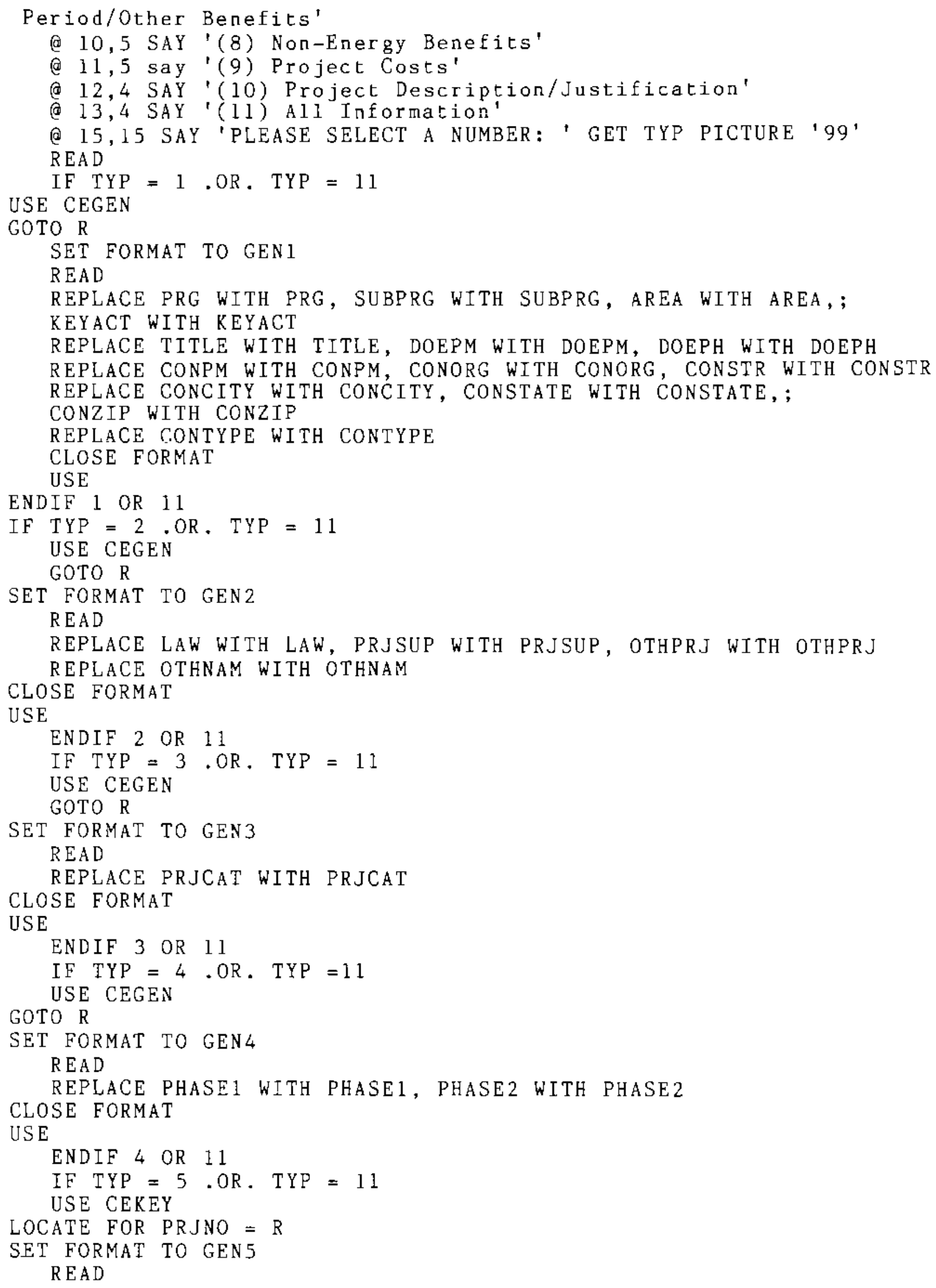


REPLACE DIS1 WITH DIS1, DIS2 WITH DIS2, DIS3 WITH DIS3,;

MATI WITH MATI

REPLACE MAT2 WITH MAT2, MAT3 WITH MAT3, TQ1 WITH TQ1, TQ2;

WITH TQ2

REPLACE TQ3 WITH TQ3, PH1 WITH PHI, PH2 WITH PH2, PH3 WITH PH3 SET FORMAT TO GEN6

READ

REPLACE EN1 WITH EN1, EN2 WITH EN2, EN3 WITH EN3, OT1 WITH OT1,; OT2 WITH OT2

REPLACE OT 3 WITH OT 3

CLOSE FORMAT

USE

ENDIF 5 OR 11

IF TYP $=6$. OR. TYP $=11$

USE CEGEN

GOTO $R$

SET FORMAT TO BEN I

READ

REPLACE OIL WITH OIL, GAS WITH GAS, COAL WITH COAL, OTHFUEL; WITH OTHFUEL

REPLACE ELECT1 WITH ELECT1, ELECT2 WITH ELECT2, UNSPC WITH UNSPC GOTO R

mNETSAV $=($ OIL + GAS + COAL + OTHFUEL + ELECT $1+$ ELECT $2+$ UNSPC $)$

REPLACE NETSAV WITH mNETSAV

@ 16,48 SAY NETSAV

CLOSE FORMAT

USE

ENDIF 6 OR 11

IF TYP $=7$. .OR. TYP $=11$

USE CEGEN

GOTO R

SET FORMAT TO BEN 2

READ

REPLACE ANNSAV WITH ANNSAV, UNITS WITH UNITS, MKTMAX WITH MKTMAX REPLACE MKTYl WITH MKTY1, MKTY2 WITH MKTY2, MKTY3 WITH MKTY3,; ACCY WITH ACCY

REPLACE MULTI WITH MULTI, ALTFUEL WITH ALTFUEL, STOR WITH STOR, ; ELOAD WITH ELOAD

CLOSE FORMAT

USE

ENDIF 7 OR 11

IF TYP $=8, O R$. TYP $=11$

USE CEGEN

GOTO R

SET FORMAT TO BEN 3

READ

REPLACE NE1 WITH NE1, NE2 WITH NE2, NE3 WITH NE3, NE4 WITH NE4 REPLACE NE5 WITH NE5

CLOSE FORMAT

USE

ENDIF 8 OR 11

IF TYP $=9.0 R$. TYP $=11$

USE CEGEN

GOTO $R$ 


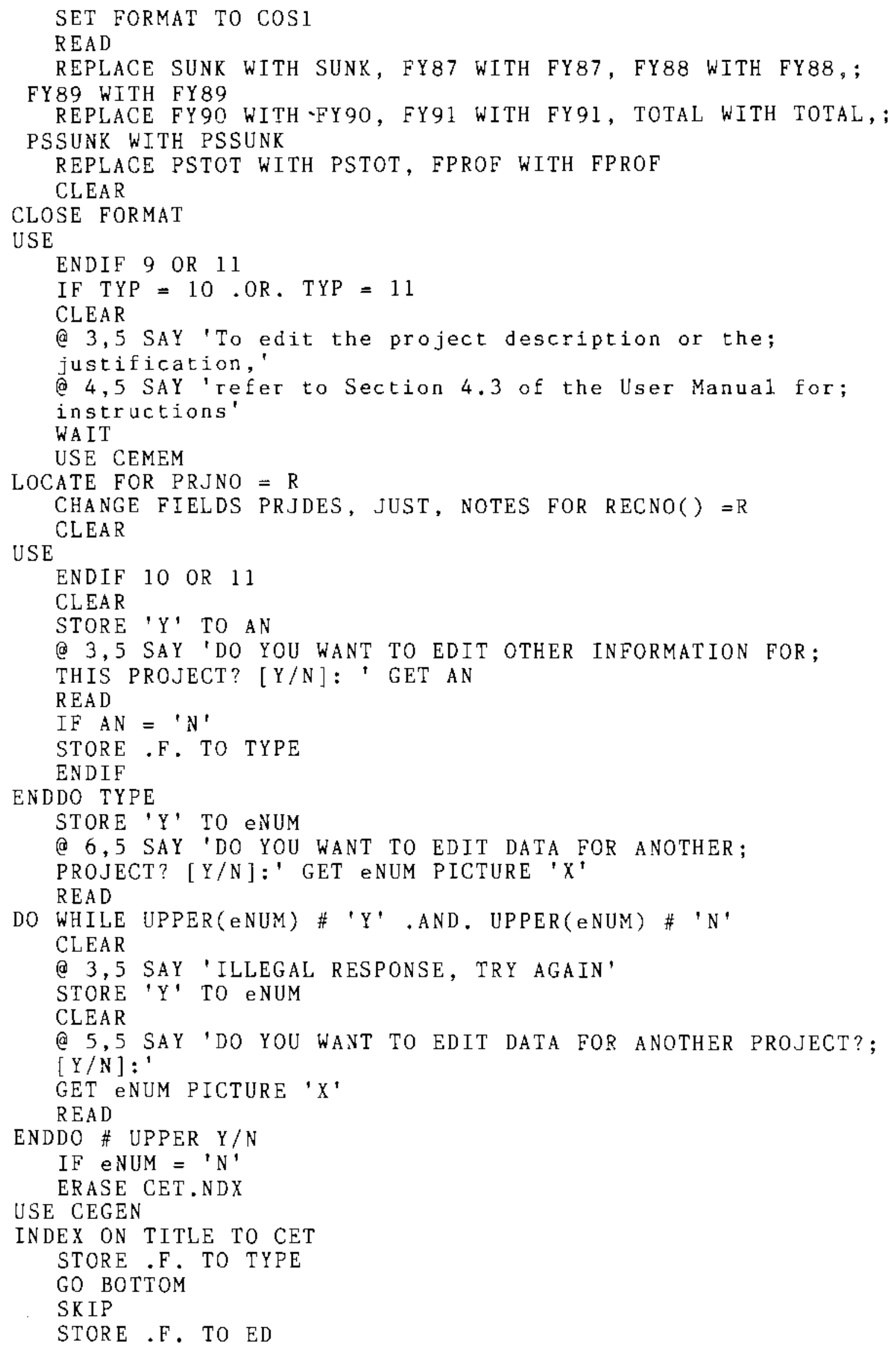




\section{ELSE}

STORE .F. TO TYPE

STORE .T. TO ED

EXIT

ENDIF

ENDDO

(i) $15,5 \mathrm{SAY}$ '

ENDDO

RELEASE ALL

CLEAR ALL

RETURN 
A. 12 


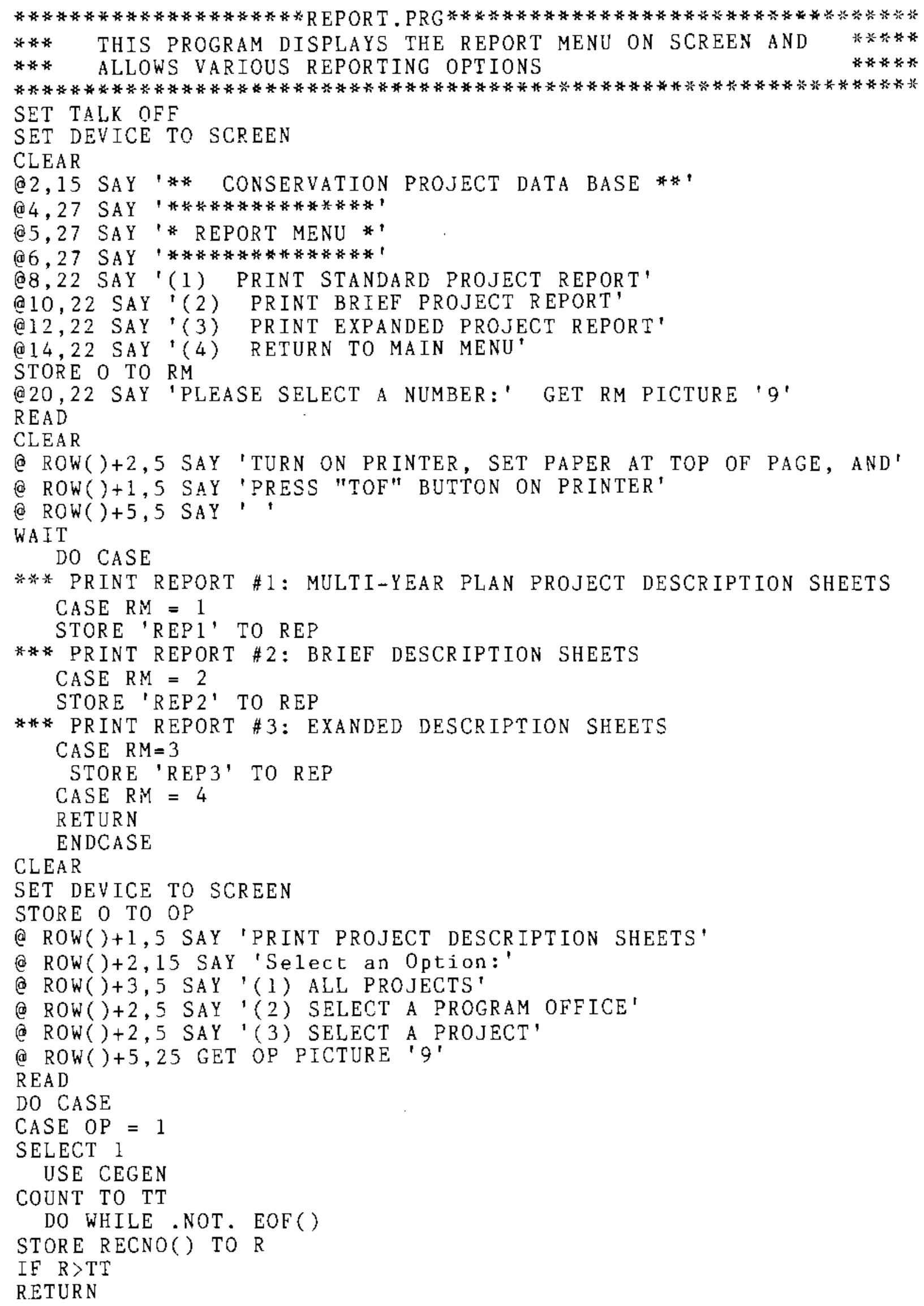

SET TALK OFF

SET DEVICE TO SCREEN

CLEAR

@2,15 SAY '* CONSERVATION PROJECT DATA BASE **

$@ 4,27$ SAY

@ 5, $27 \mathrm{SAY}$

@6,27 SAY

@8,22 SAY '(1) PRINT STANDARD PROJECT REPORT'

Q 10,22 SAY ' (2) PRINT BRIEF PROJECT REPORT'

@12,22 SAY '( 3 ) PRINT EXPANDED PROJECT REPORT'

@14,22 $\mathrm{SAY}^{\prime}(4)$ RETURN TO MAIN MENU'

STORE 0 TO RM

@20,22 SAY 'PLEASE SELECT A NUMBER:' GET RM PICTURE ' 9 '

READ

CLEAR

(2) ROW( $)+2,5$ SAY 'TURN ON PRINTER, SET PAPER AT TOP OF PAGE, AND'

( ROW( ) $+1,5$ SAY 'PRESS "TOF" BUTTON ON PRINTER'

(a) ROW ( ) +5,5 SAY''

WAIT

DO CASE

** PRINT REPORT \#1: MULTI-YEAR PLAN PROJECT DESCRIPTION SHEETS CASE RM $=1$ STORE 'REP1' TO REP

* * PRINT REPORT \#2: BRIEF DESCRIPTION SHEETS

CASE RM $=2$

STORE 'REP2' TO REP

* * PRINT REPORT \#3: EXANDED DESCRIPTION SHEETS

CASE RM=3

STORE 'REP3' TO REP

CASE RM $=4$

RETURN

ENDCASE

CLEAR

SET DEVICE TO SCREEN

STORE O TO OP

(a) ROW( $)+1,5$ SAY 'PRINT PROJECT DESCRIPTION SHEETS'

(2) ROW( $)+2,15$ SAY 'Select an 0ption:'

(2) ROW ( ) +3,5 SAY '(1) ALL PROJECTS'

@ ROW ( $)+2,5$ SAY '(2) SELECT A PROGRAM OFFICE'

(a ROW ()$+2,5$ SAY ' ( 3 ) SELECT A PROJECT'

(a) ROW ( ) $+5,25$ GET OP PICTURE ' 9 '

READ

DO CASE

CASE OP $=1$

SELECT 1

USE CEGEN

COUNT TO TT

DO WHILE . NOT. EOF()

STORE RECNO() TO R

IF $\quad R>T$ T

RETURN

A. 13 


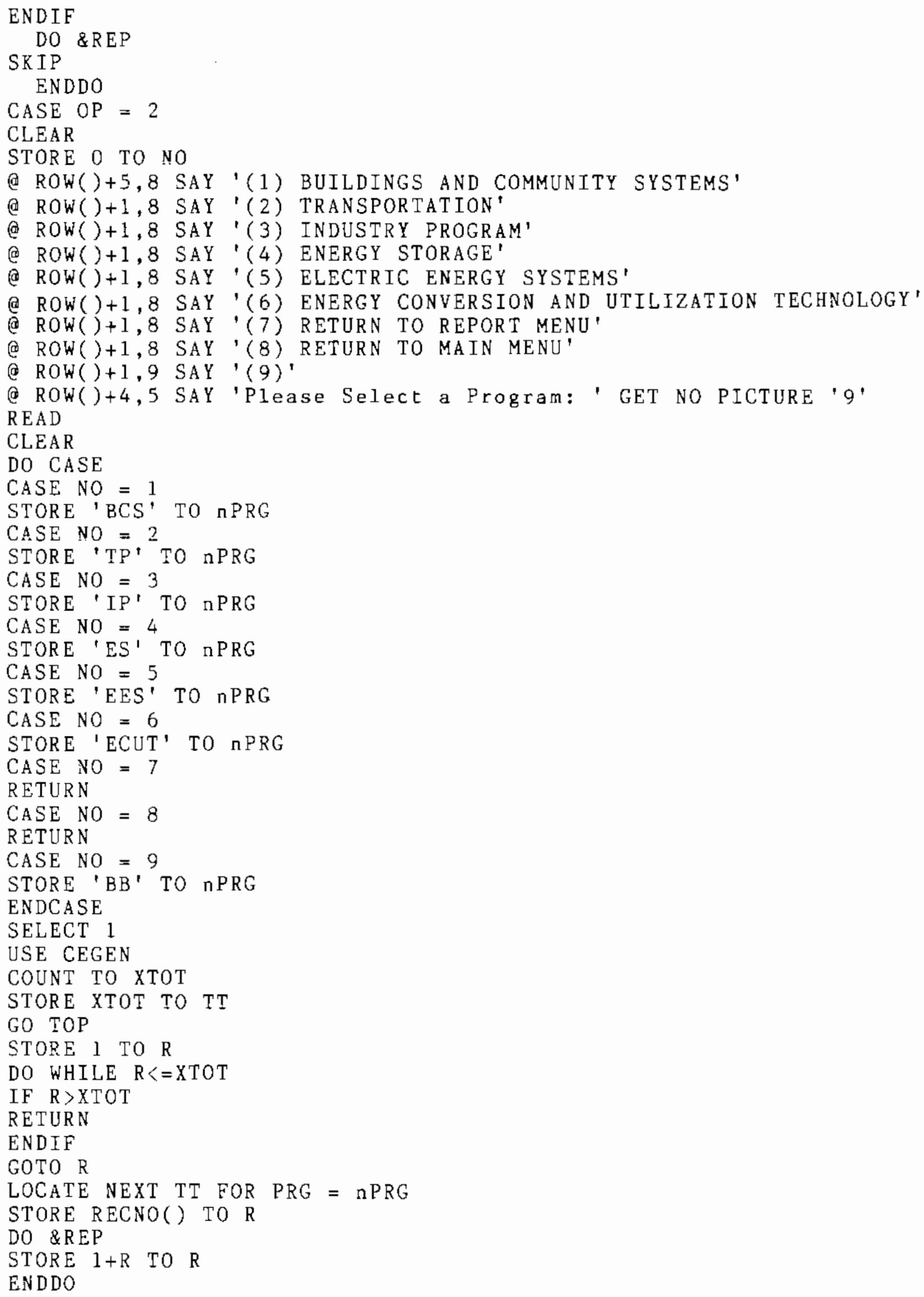




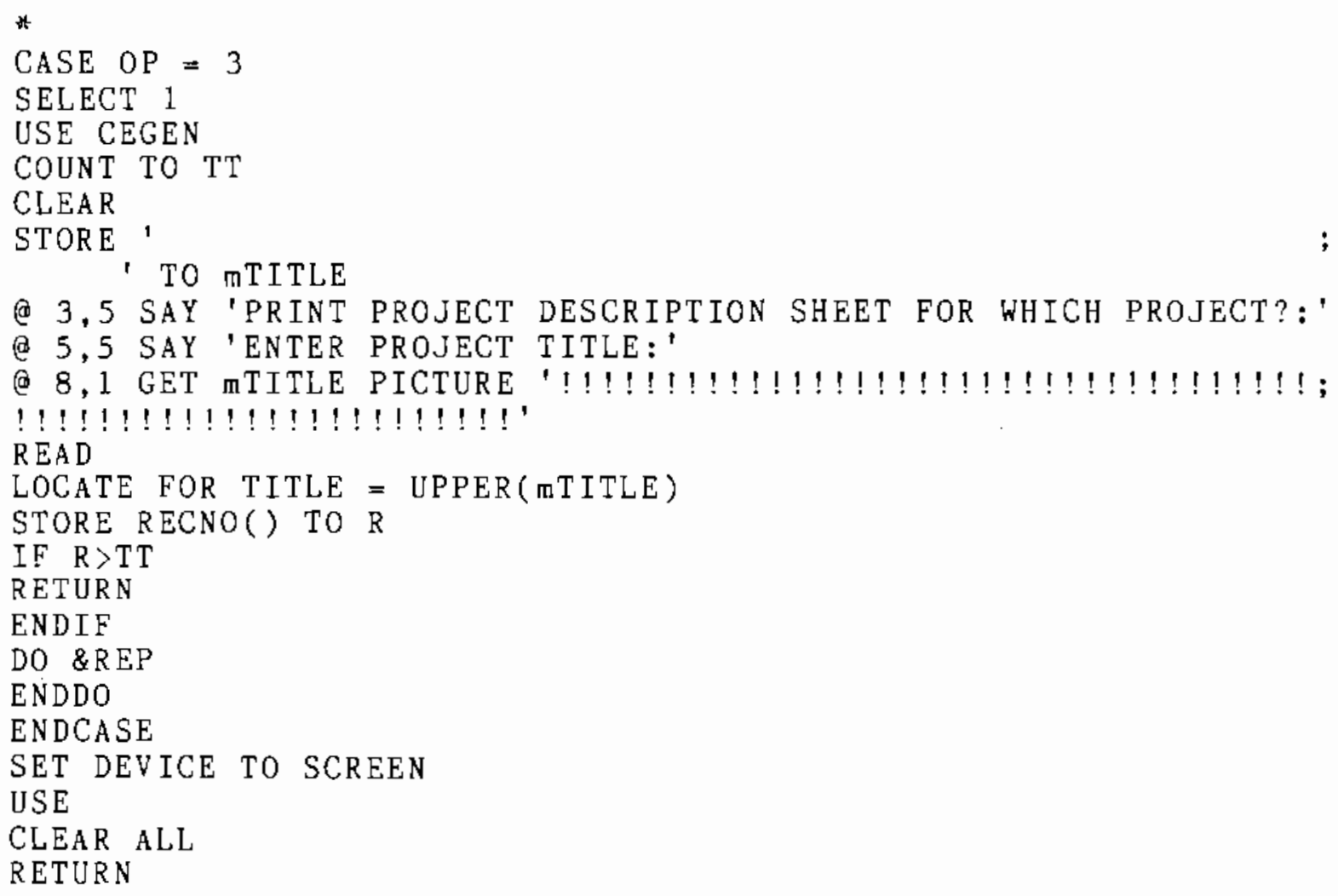




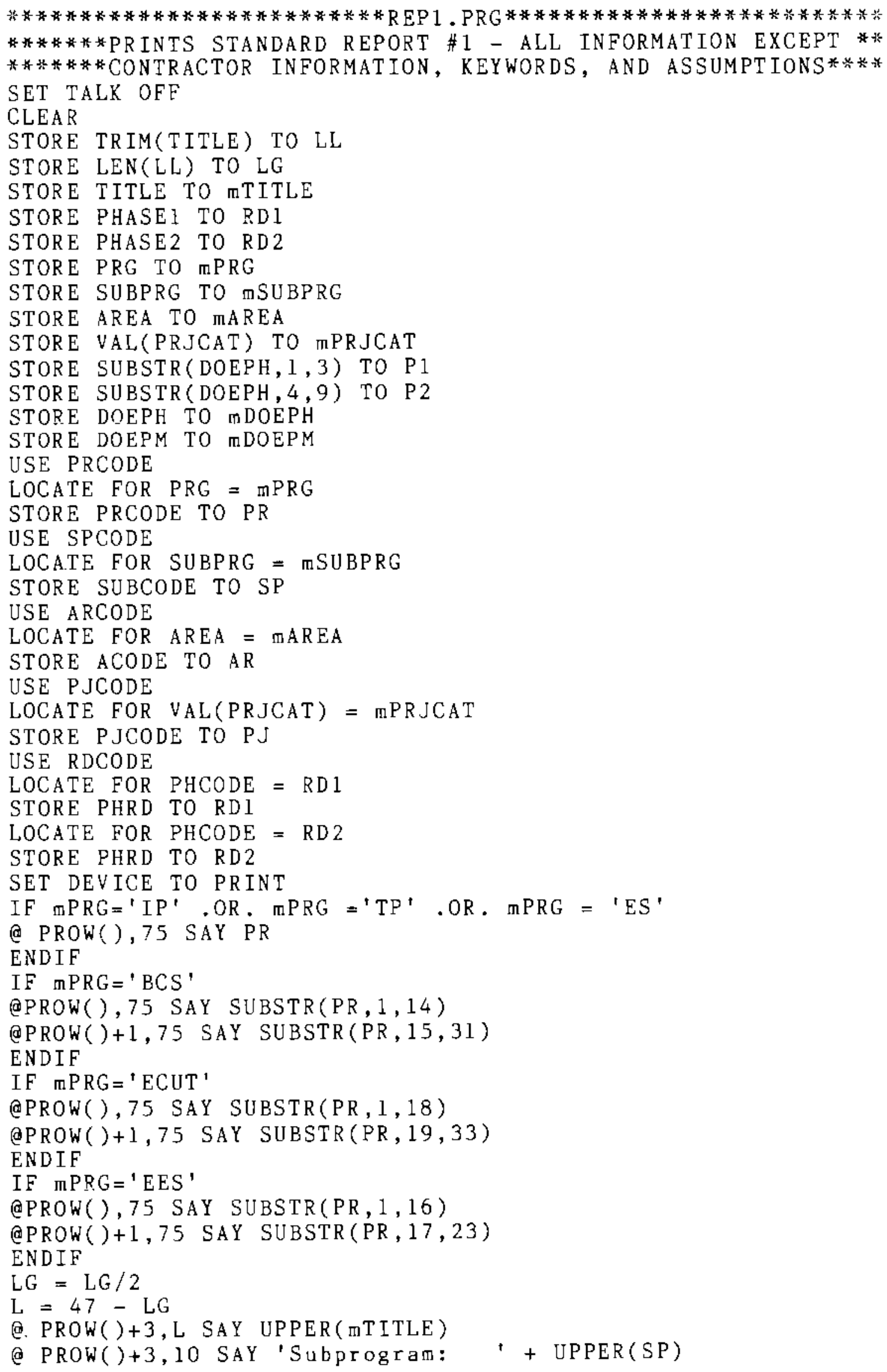




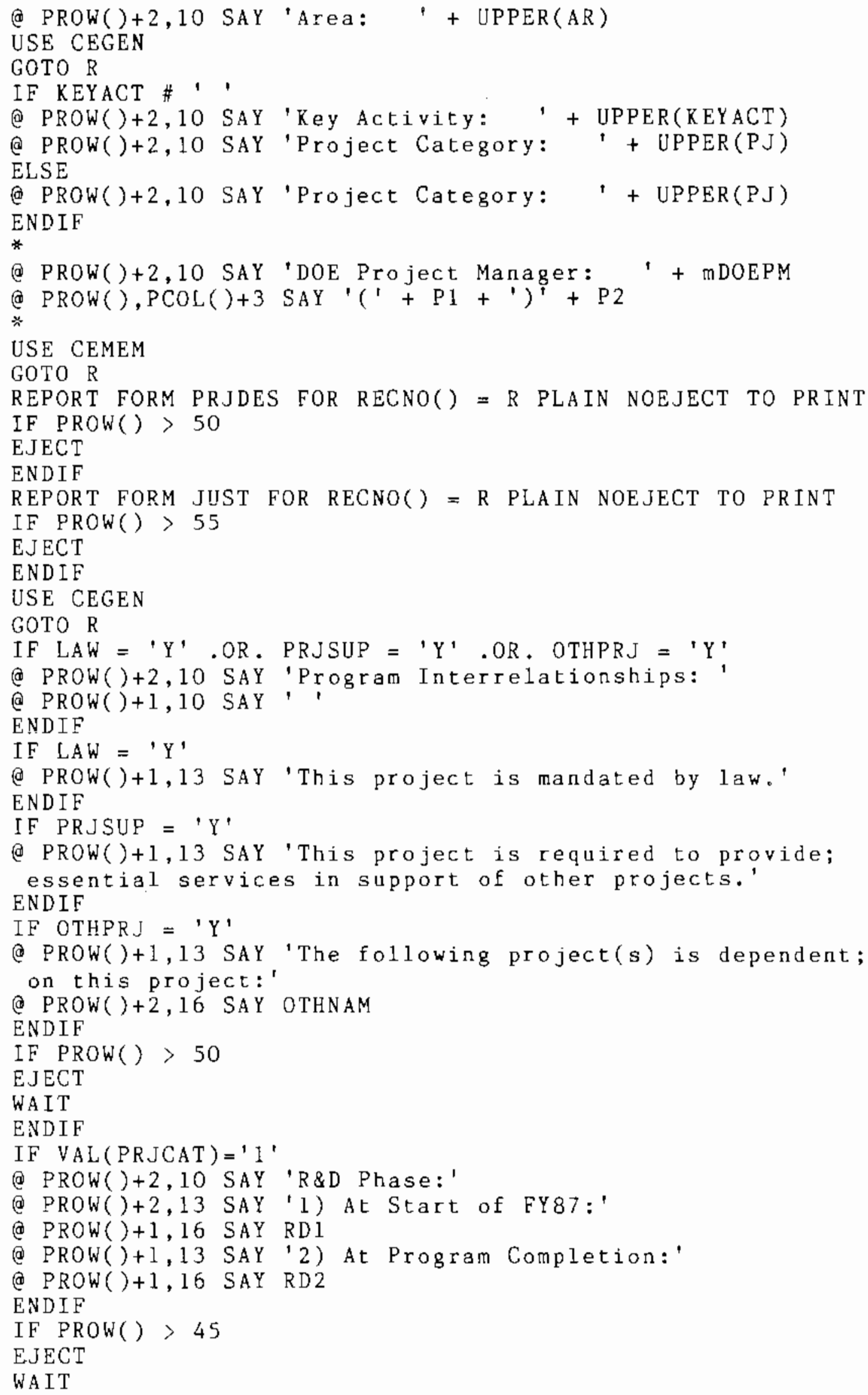




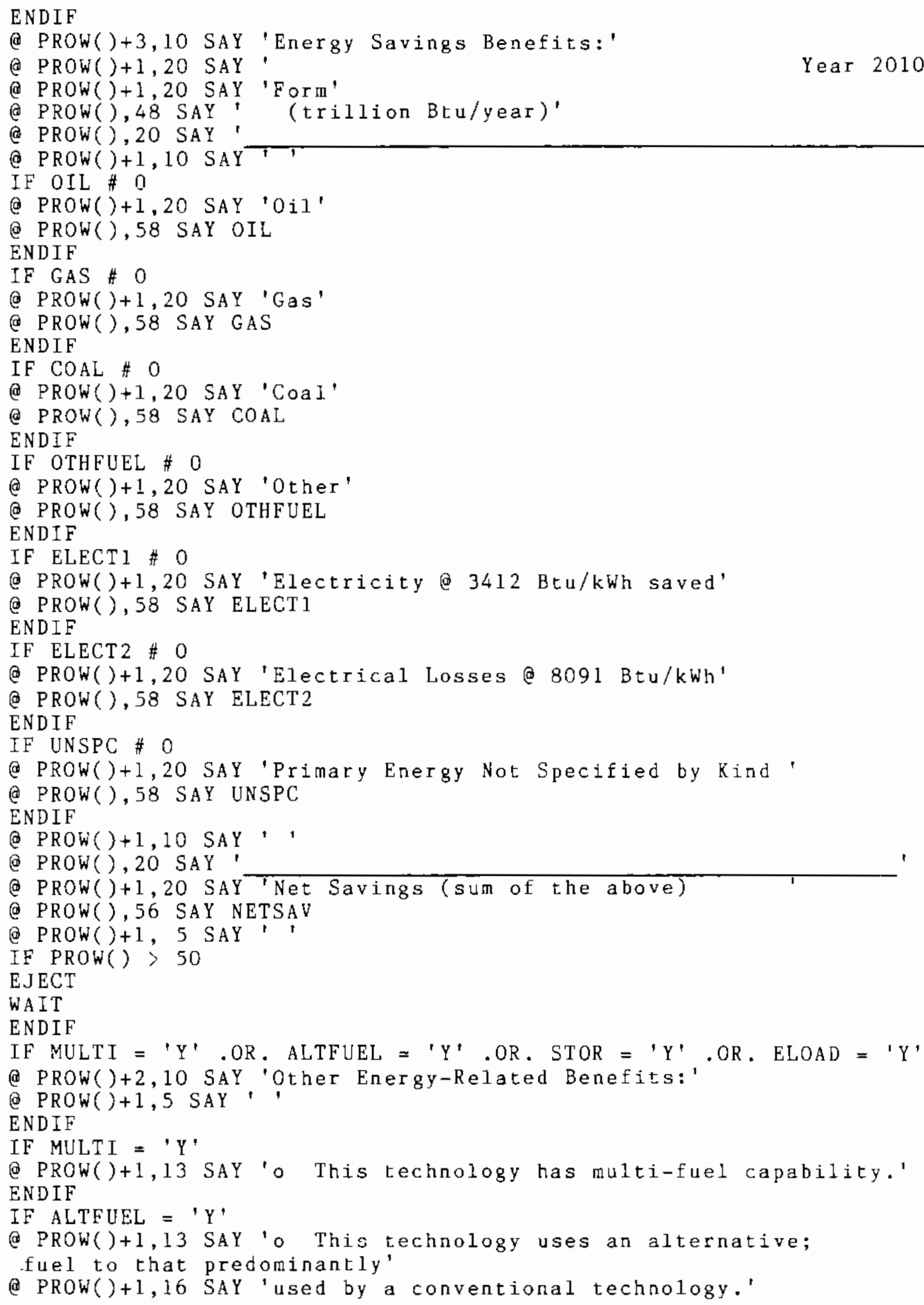




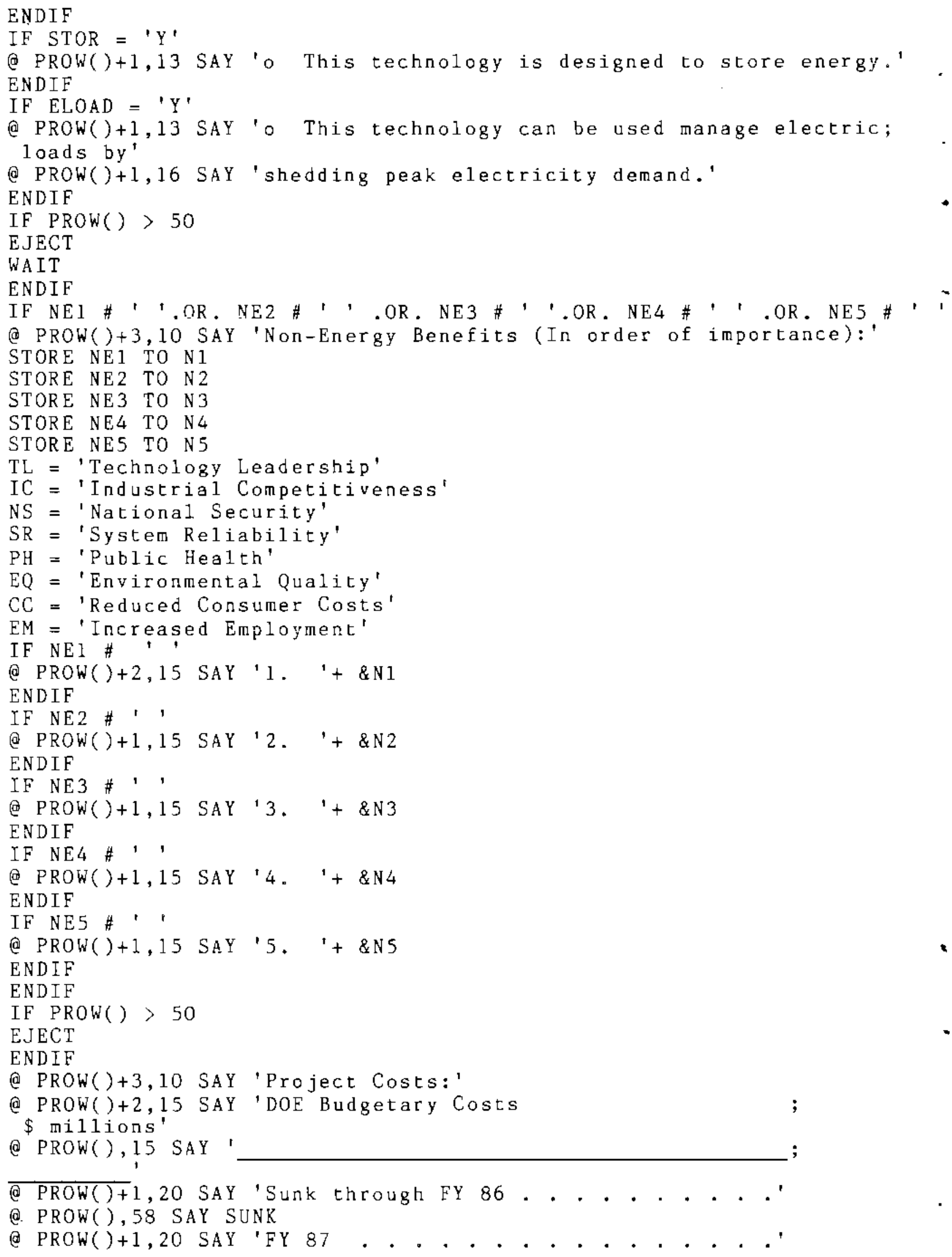


(e) PROW(), 58 SAY FY 87

(e) PROW( $+1,20$ SAY 'FY 88 . + . . . . . . . . . . . . . . . . .'

(e) PROW( ), 58 SAY FY 88

(e) PROW( ) +1,20 SAY 'FY 89

(d) PROW( ), 58 SAY FY 89

(C) PROW ()$+1,20$ SAY 'FY 90 . . . . . . . . . . . . . . . .'

(a) PROW( ), 58 SAY FY 90

(e) PROW( $+1,20$ SAY 'FY 91 .

(d) PROW( ), 58 SAY FY91

@ PROW( $)+1,20$ SAY 'Cumulative FY 87 through Completion. .'

@ PROW( ), 58 SAY TOTAL

@ PROW( ) +2,15 SAY 'Private Sector Contributions ; $\$$ millions'

(a) PROW( ), 15 SAY '

@ PROW() $+1,20$ SAY 'Sunk through FY 86 . . . . . . . . . .'

(d PROW( ), 58 SAY PSSUNK

( PROW( )+1,20 SAY 'Cumulative FY 87 through Completion. .'

(a) PROW( ), 56 SAY PSTOT

@ PROW ( $+1,5$ SAY,'

EJECT

WAIT

RELEASE ALL EXCEPT R

RETURN 
$22 \cdot \forall$

$\bullet$

$$
\text { . }
$$




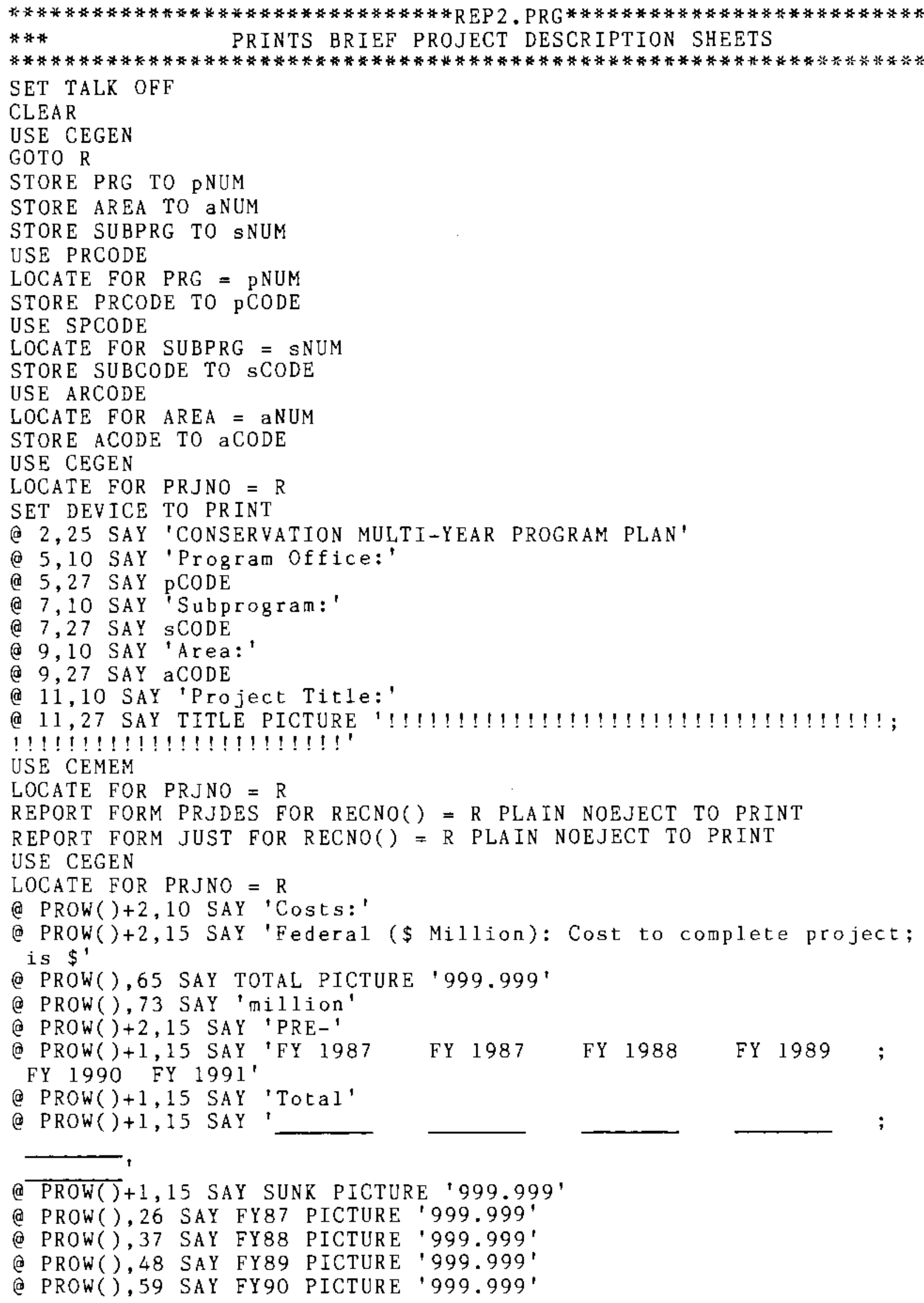


(e) PROW( ),70 SAY FY91 PICTURE '999.999'

(a) PROW()+3,10 SAY 'H.Q. Point of Contact:'

(a) PROW( ), 35 SAY DOEPM PICTURE ' XXXXXXXXXXXXXXXXXXXXXXXXX'

(e) PROW( $+2,10$ SAY 'Telephone Number:'

STORE SUBSTR(DOEPH, 1,3 ) TO P1

STORE SUBSTR(DOEPH, 4,9) TO P2

@ PROW( ), 35 SAY ' $(1+P 1+')^{\prime}+P 2$

(e) PROW( $+1,1$ SAY

EJECT

RETURN 


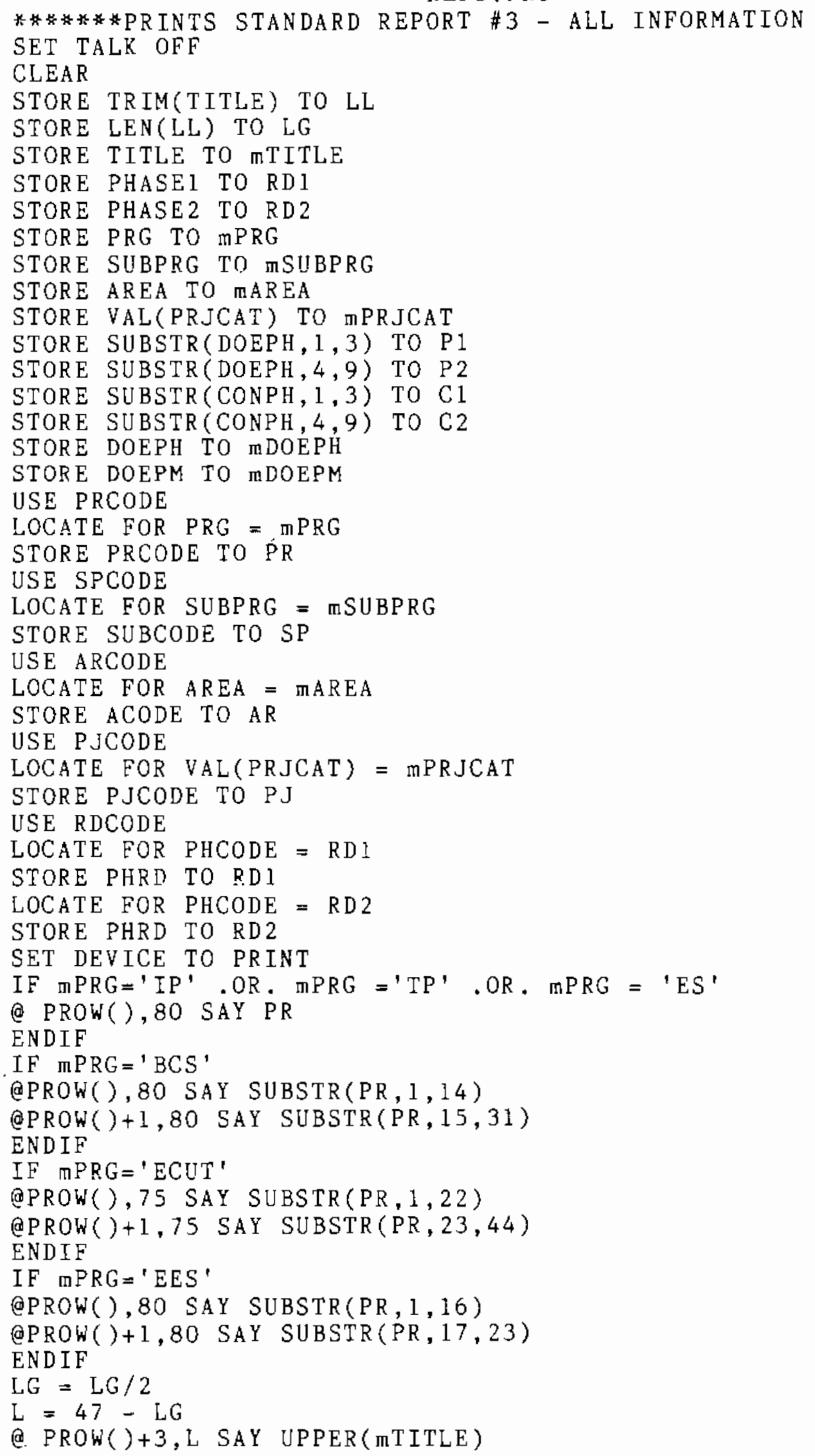




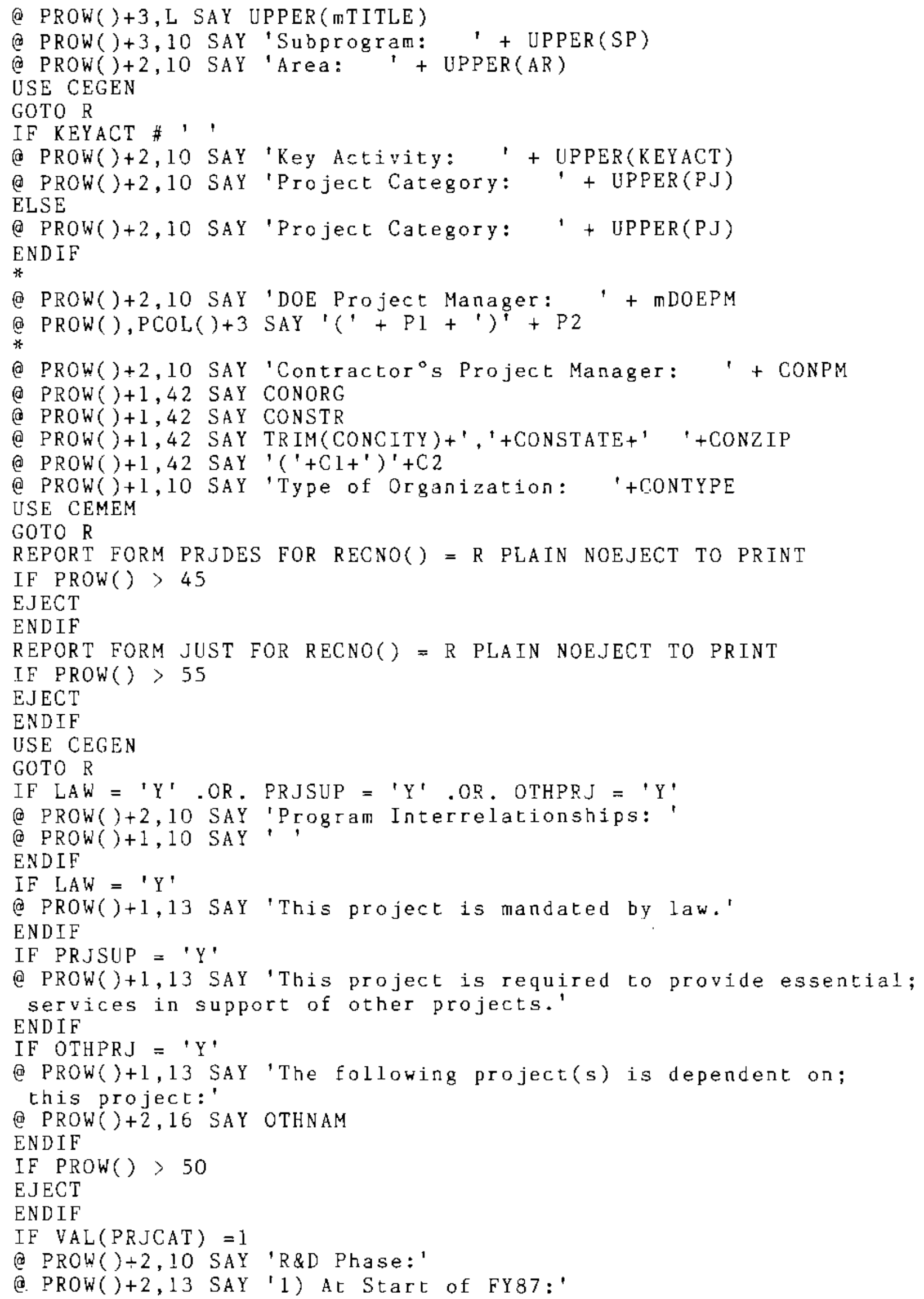




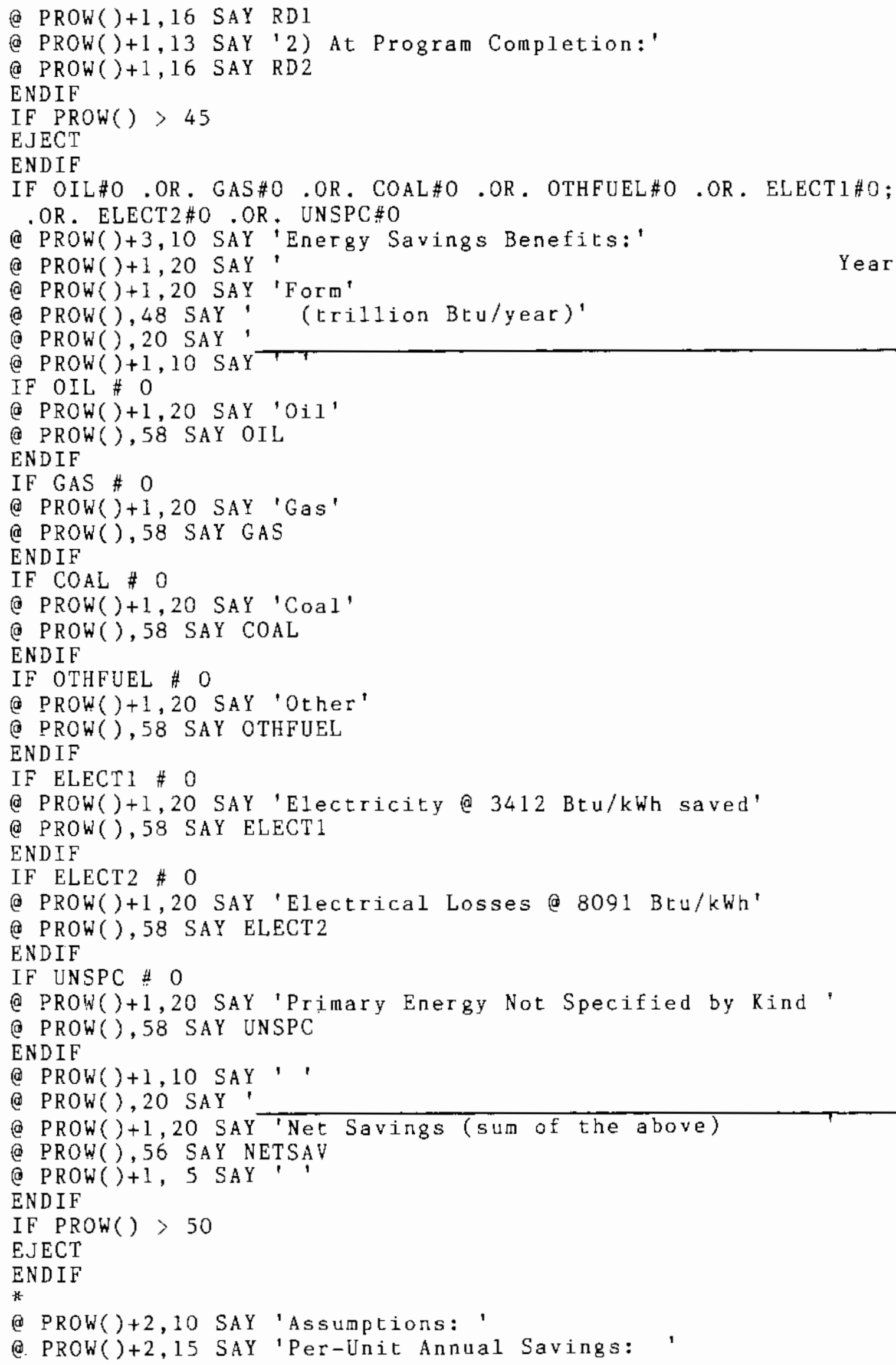


(e) PROW( ), 45 SAY ANNSAV

(e) PROW( ) $+1,15$ SAY 'Year 2010 Market (Number of Units): '+ MARKET

(2) PROW( $+1,15$ SAY 'Maximum Potential Market Penetration (\%):

@ PROW( ), 58 SAY MKTMAX

@ PROW( $+1,15$ SAY 'Market Penetration Curve:'

@ PROW ()$+1,20$ SAY 'Year A: '+MKTYl

@ PROW( $+1,20$ SAY 'Year B: '+MKTY 2

(aROW ( ) +1,20 SAY 'Year C: '+MKTY3

(d) PROW()+2,10 SAY 'ACCeleration Period (years): '+ACCY

IF PROW( ) > 50

EJECT

ENDIE

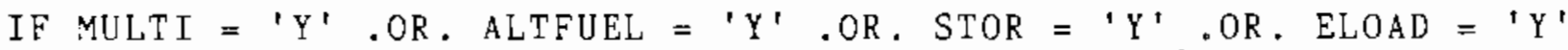

@ PROW ()$+2,10$ SAY 'Other Energy-Related Benefits:'

(a) PROW ( ) $+1,5$ SAY',

ENDIF

IF MULTI $={ }^{\prime} \mathrm{Y}^{\prime}$

(a) PROW( $+1,13$ SAY 'O This technology has multi-fuel capability.'

ENDIF

IF ALTFUEL $=$ ' $Y$ '

@ PROW( $+1,13$ SAY 'o This technology uses an alternative;

fuel to that predominantly'

@ PROW ( ) +1,16 SAY 'used by a conventional technology.'

ENDIF

IF $S T O R=$ ' $Y$ '

@ PROW ()$+1,13$ SAY 'o This technology is designed to store energy.'

ENDIF

IF $E L O A D=$ ' $Y$ '

@ PROW( $+1,13$ SAY 'o This technology can be used manage;

electric loads by'

@ PROW ()$+1,16$ SAY 'shedding peak electricity demand.'

ENDIF

IF PROW( ) > 50

EJECT

ENDIF

IF NE1 \#' ', OR . NE2 \#'', .OR. NE3 \#' '.OR. NE4 \#'', .OR. NE5 \#' ' (e PROW( ) $+3,10$ SAY 'Non-Energy Benefits (In order of importance):' STORE NEI TO NI

STORE NE2 TO N2

STORE NE3 TO N3

STORE NE4 TO N4

STORE NE5 TO N5

$T L=$ 'Technology Leadership'

$I C=$ 'Industrial Competitiveness'

NS = 'National Security'

$\mathrm{SR}=$ 'System Reliability'

$\mathrm{PH}=$ 'Public Health'

$\mathrm{EQ}={ }^{\prime}$ Environmenta1 Quality'

$\mathrm{CC}=$ 'Reduced Consumer Costs'

EM = 'Increased Employment'

IF NE1\#,

(a) PROW( ) $+2,15$ SAY 'o '+\&NI

ENDIF

IF NE2 \# ' 


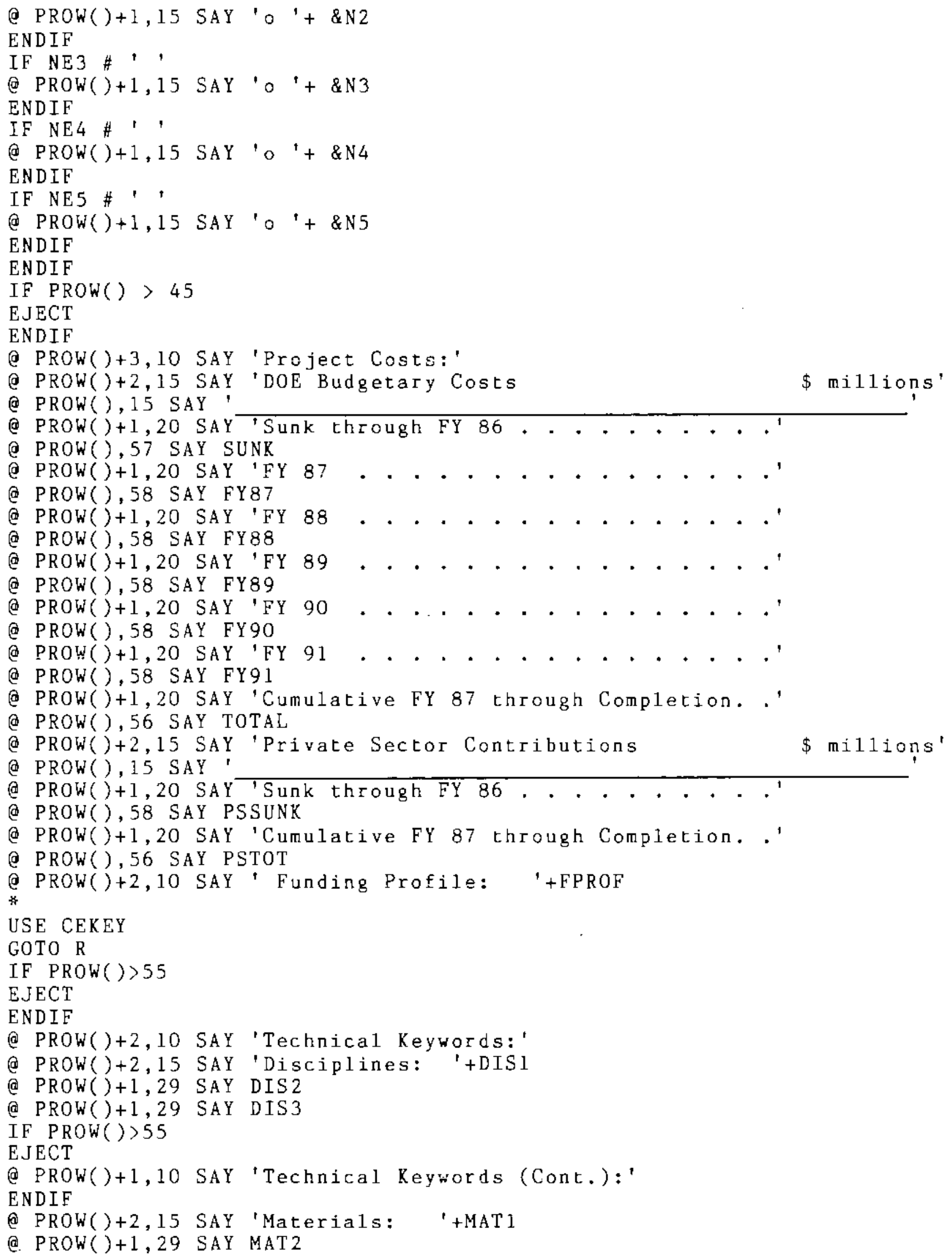




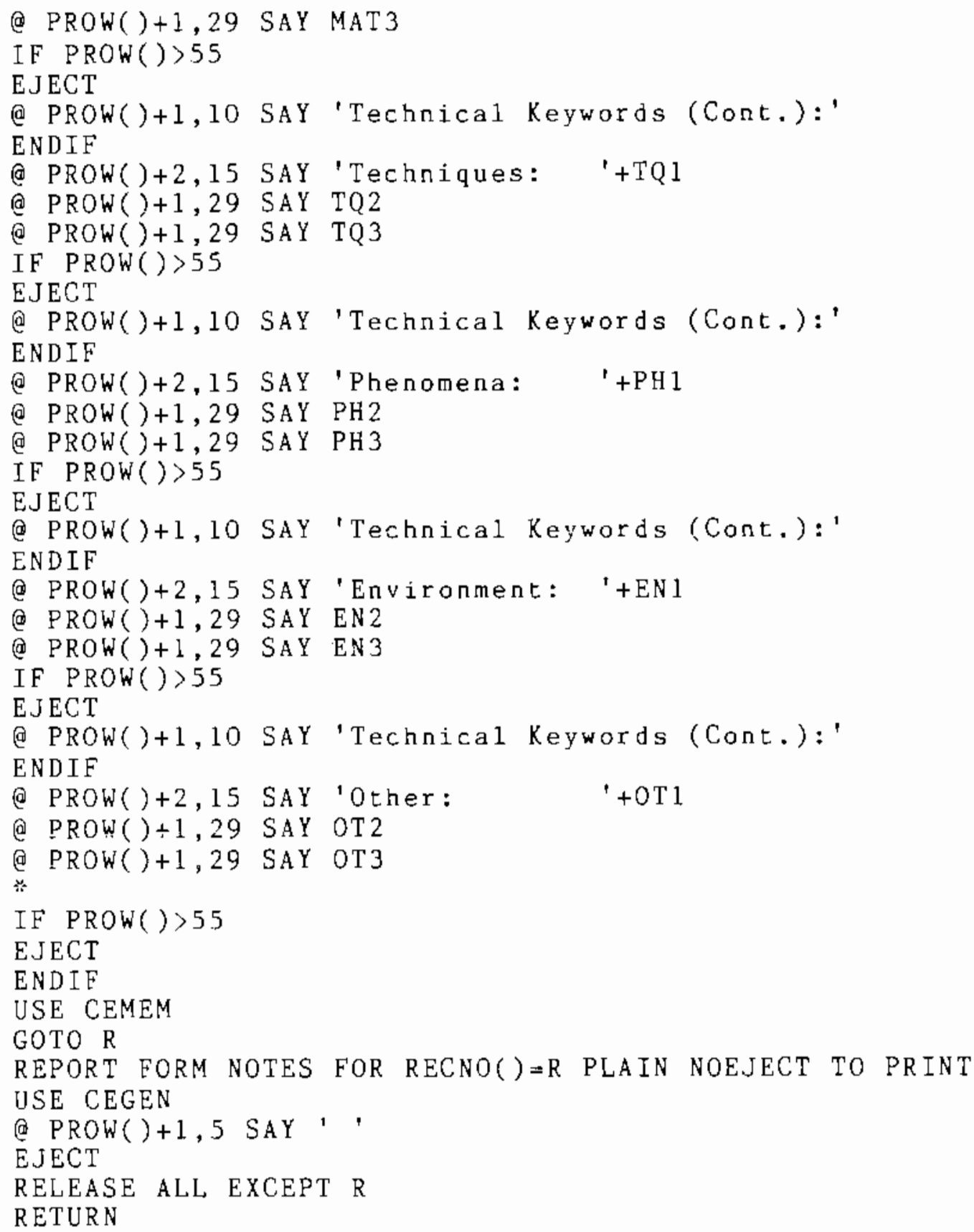




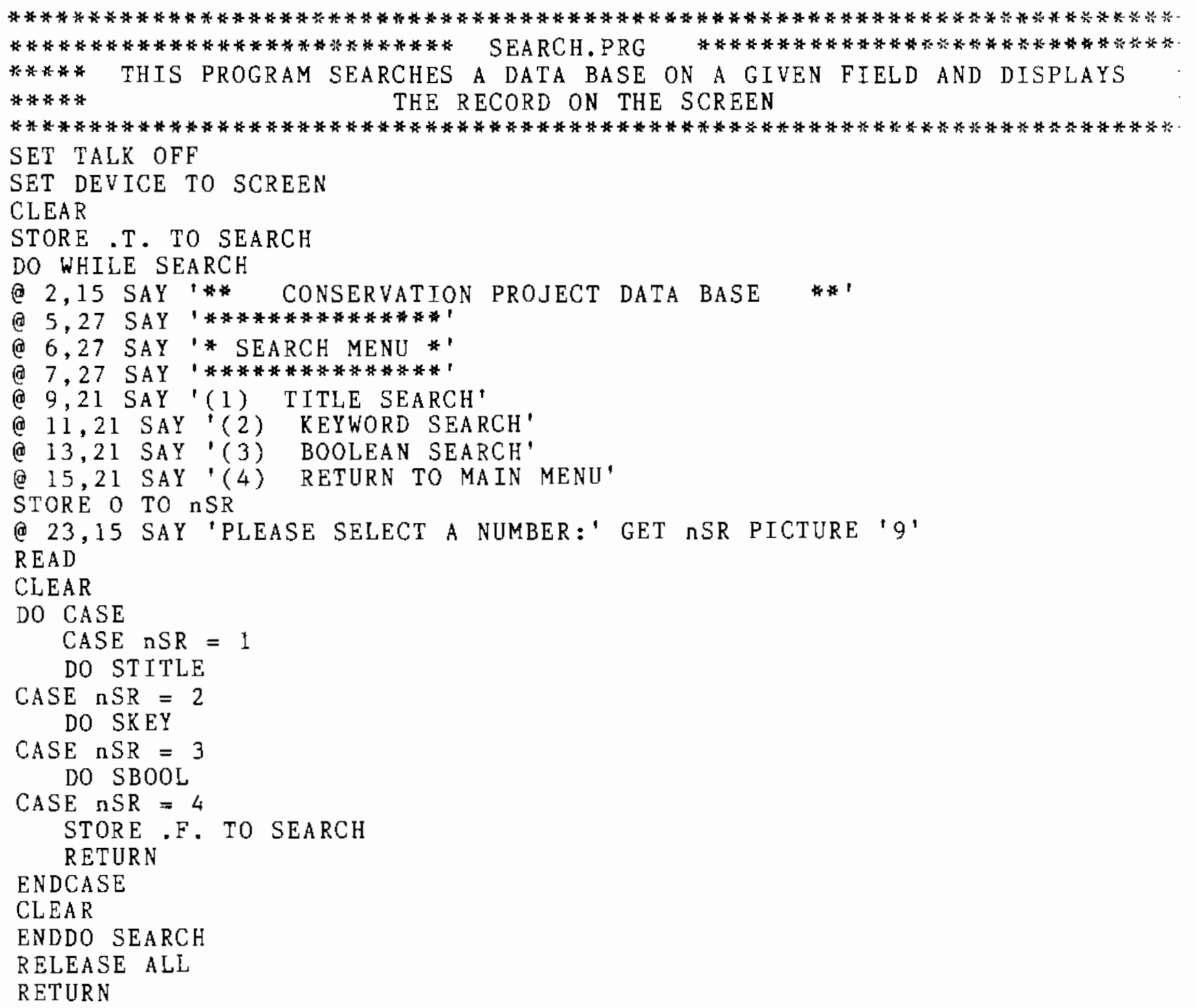




\section{$\checkmark$}

$-$ 


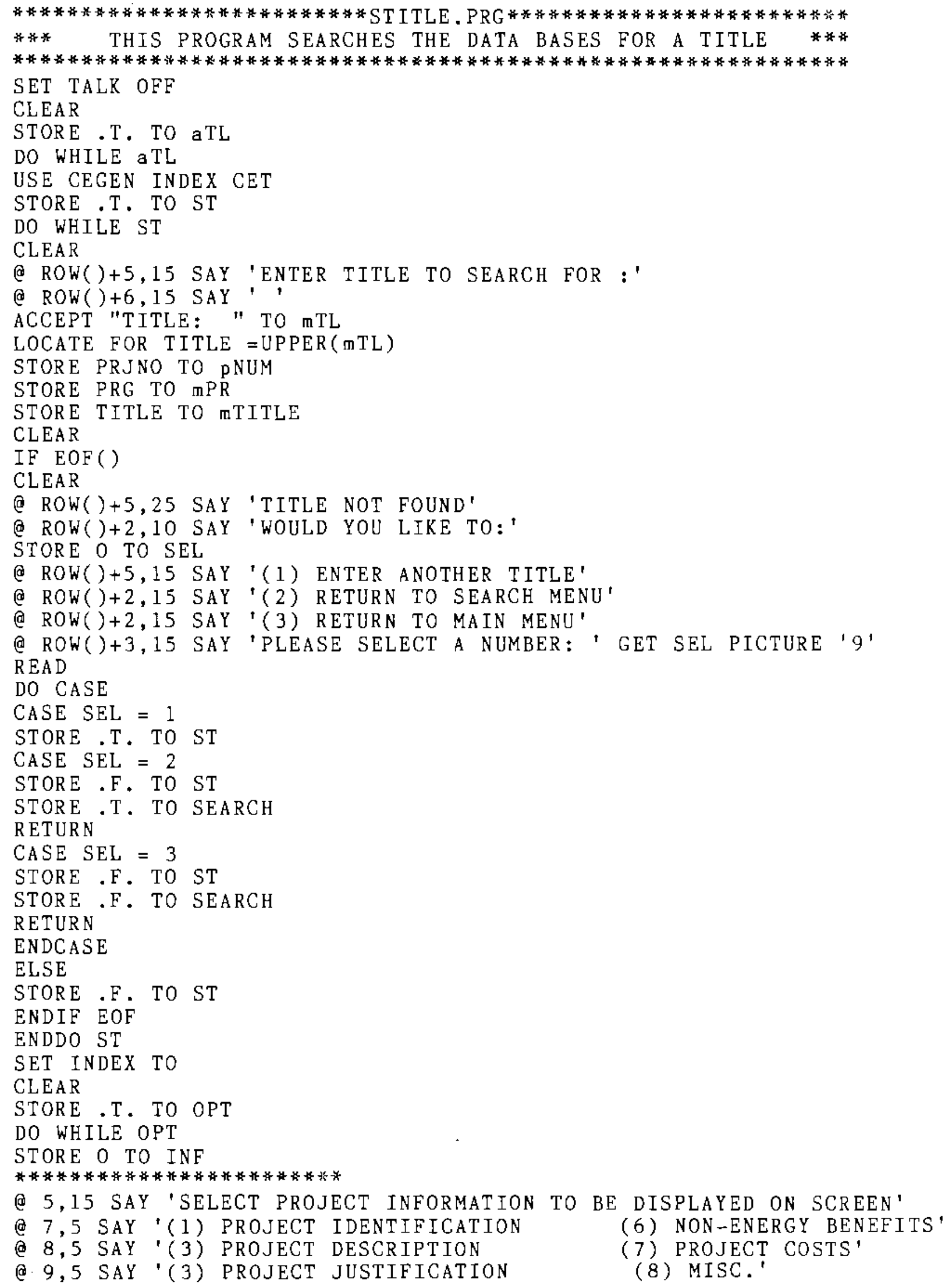


@ 10,5 SAY '(4) ENERGY SAVINGS

@ 11,5 SAY ' (5) ENERGY-RELATED BENEFITS

@ 16,15 SAY 'PLEASE SELECT A NUMBER' GET

READ

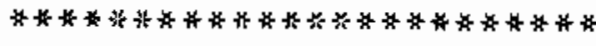

IF INF $=1$, OR. INF $=9$

USE CEGEN

LOCATE FOR PRJNO $=p N U M$.AND. $P R G=m P R$

SET FORMAT TO GEN 1

READ

CLOSE FORMAT

USE

ENDIF

$I F \quad I N F=2 . O R . I N F=9$

CLEAR

USE CEMEM

LOCATE FOR PRJNO = PNUM. AND. PRG $=m P R$ DISPLAY OFF PRJDES

USE

(e) ROW( )+1, 5 SAY',

WAIT

ENDIF

IF $I N F=3 \cdot$ OR. INF $=9$

CLEAR

USE CEMEM

LOCATE FOR PRJNO $=\mathrm{pNUM}$. AND. $P R G=m P R$

DISPLAY OFF JUST

USE

(d) ROW ( )+1,5 SAY ',

WAIT

ENDIF

IF INF $=4.0 R$. INF $=9$

USE CEGEN

LOCATE FOR PRJNO $=\mathrm{pNUM}$. AND. $P R G=m P R$

SET FORMAT TO BEN 1

READ

@ 16,48 SAY NETSAV

WA IT

CLOSE FORMAT

USE

ENDIF

IF INF $=5$. OR. INF $=9$

USE CEGEN

LOCATE FOR PRJNO $=p N U M$. AND. $P R G=m P R$ SET FORMAT TO BEN2

READ

CLOSE FORMAT

USE

ENDIF

IF INF $=6$. OR. INF $=9$

USE CEGEN

LOCATE FOR PRJNO = pNUM.AND. $P R G=m P R$ SET FORMAT TO BEN3

READ

CLOSE FORMAT
(9) ALL"

(10) RETURN TO MAIN MENU'

INF PICTURE '99' 


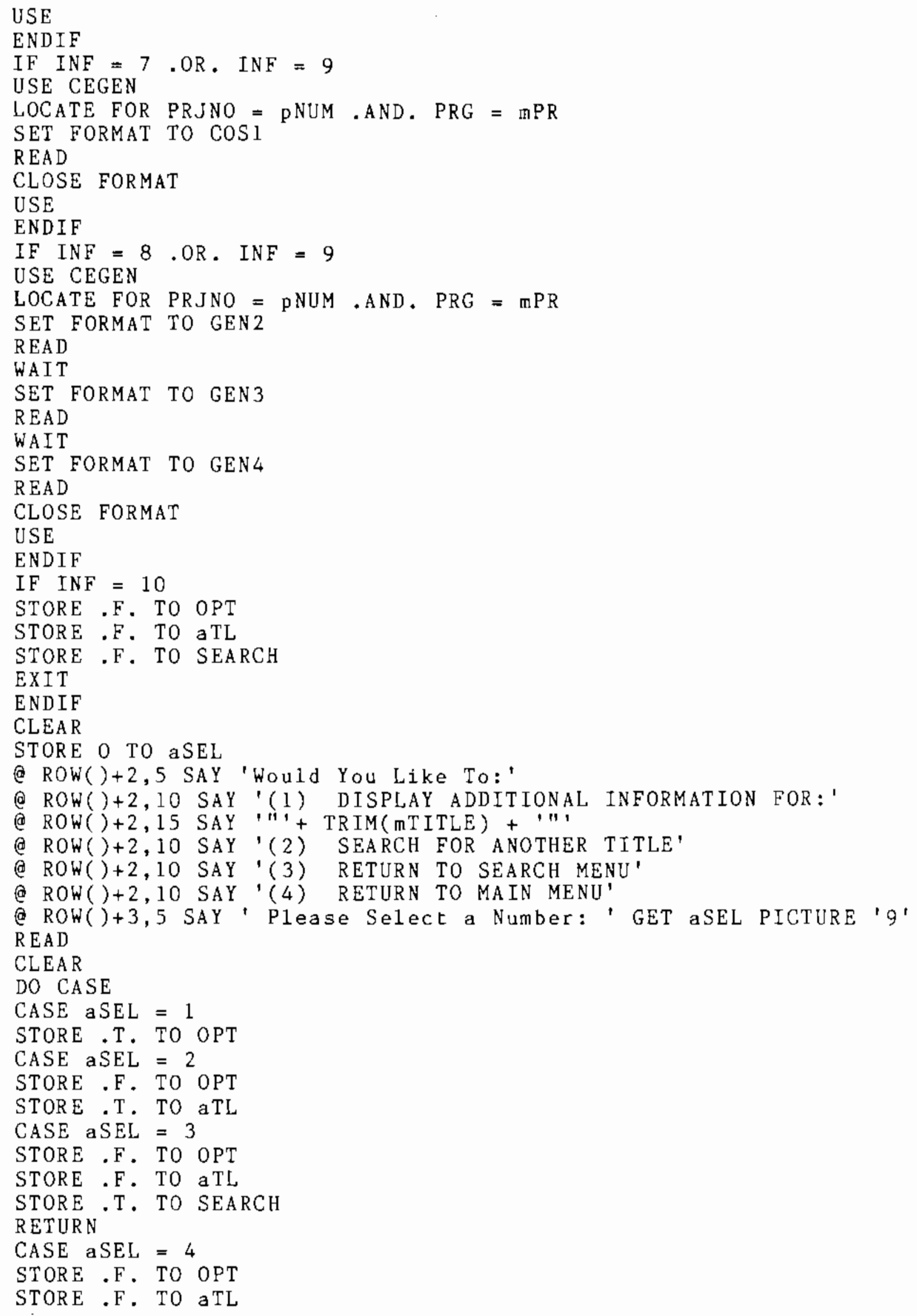


STORE . F . TO SEARCH

STORE.T. TO MAIN

RETURN TO MASTER

ENDCASE

@ 15,5 SAY' '

ENDDO OPT

ENDDO aTL

RELEASE ALL

CLOSE FORMAT

RETURN

A. 36 


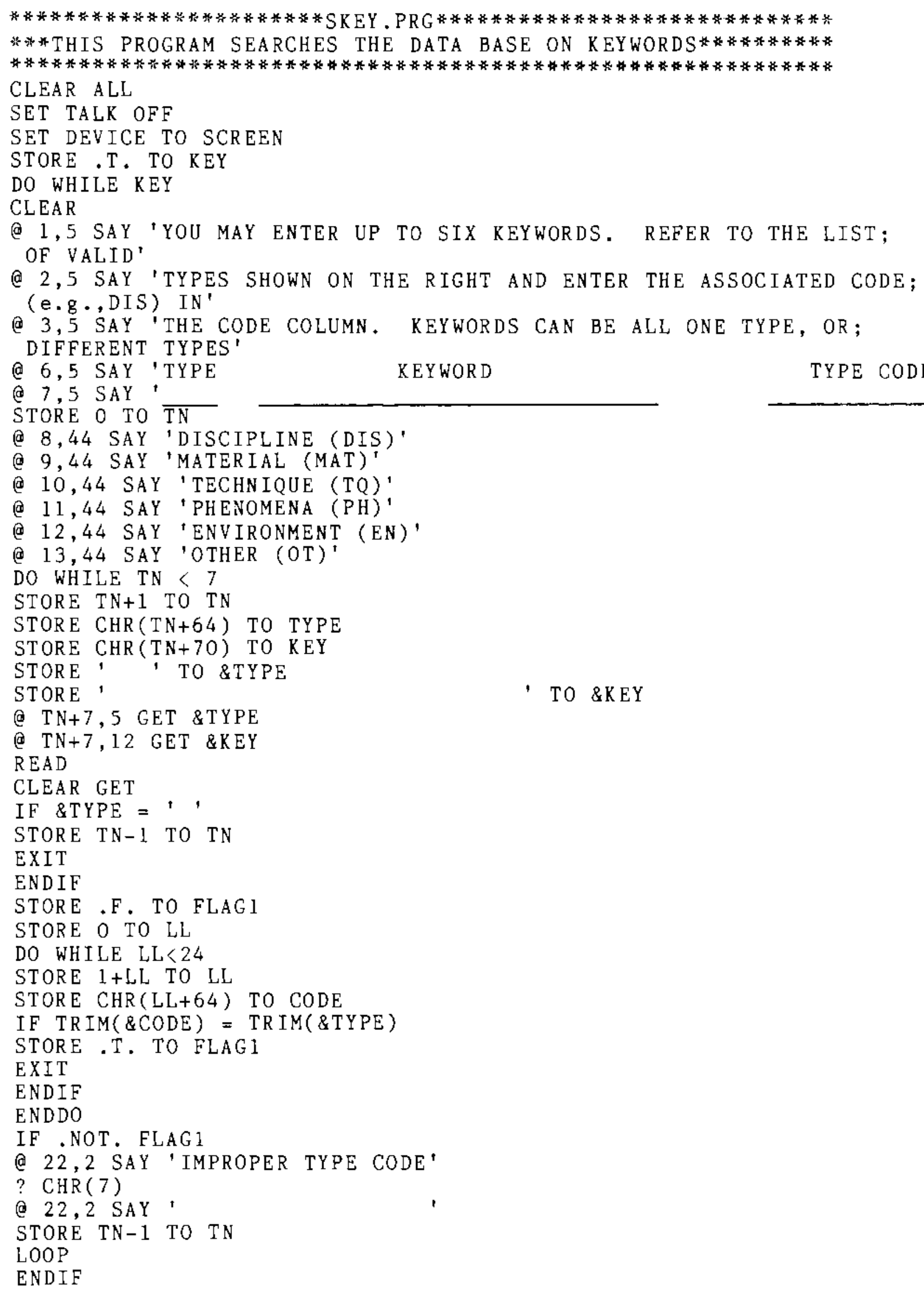




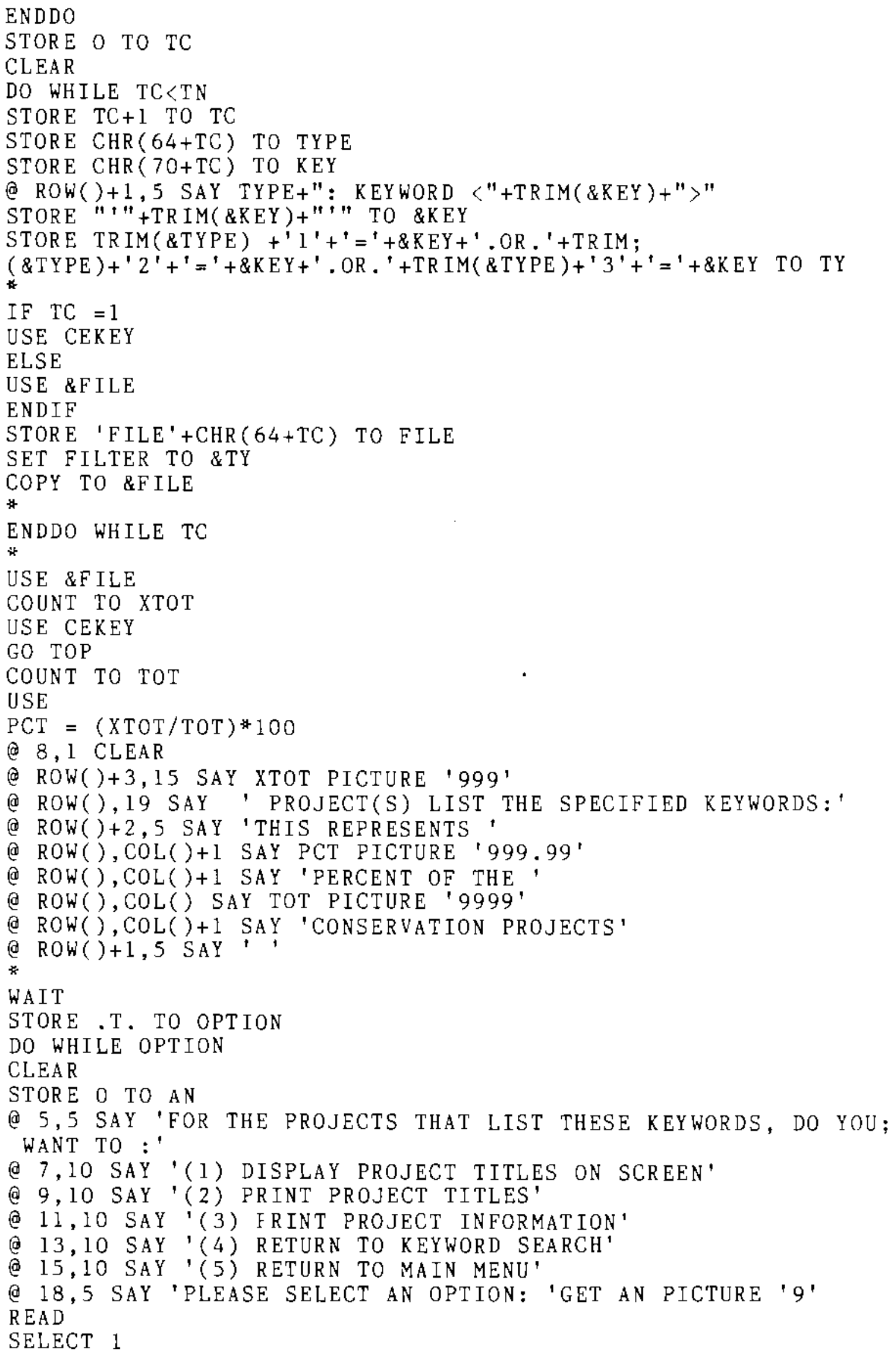




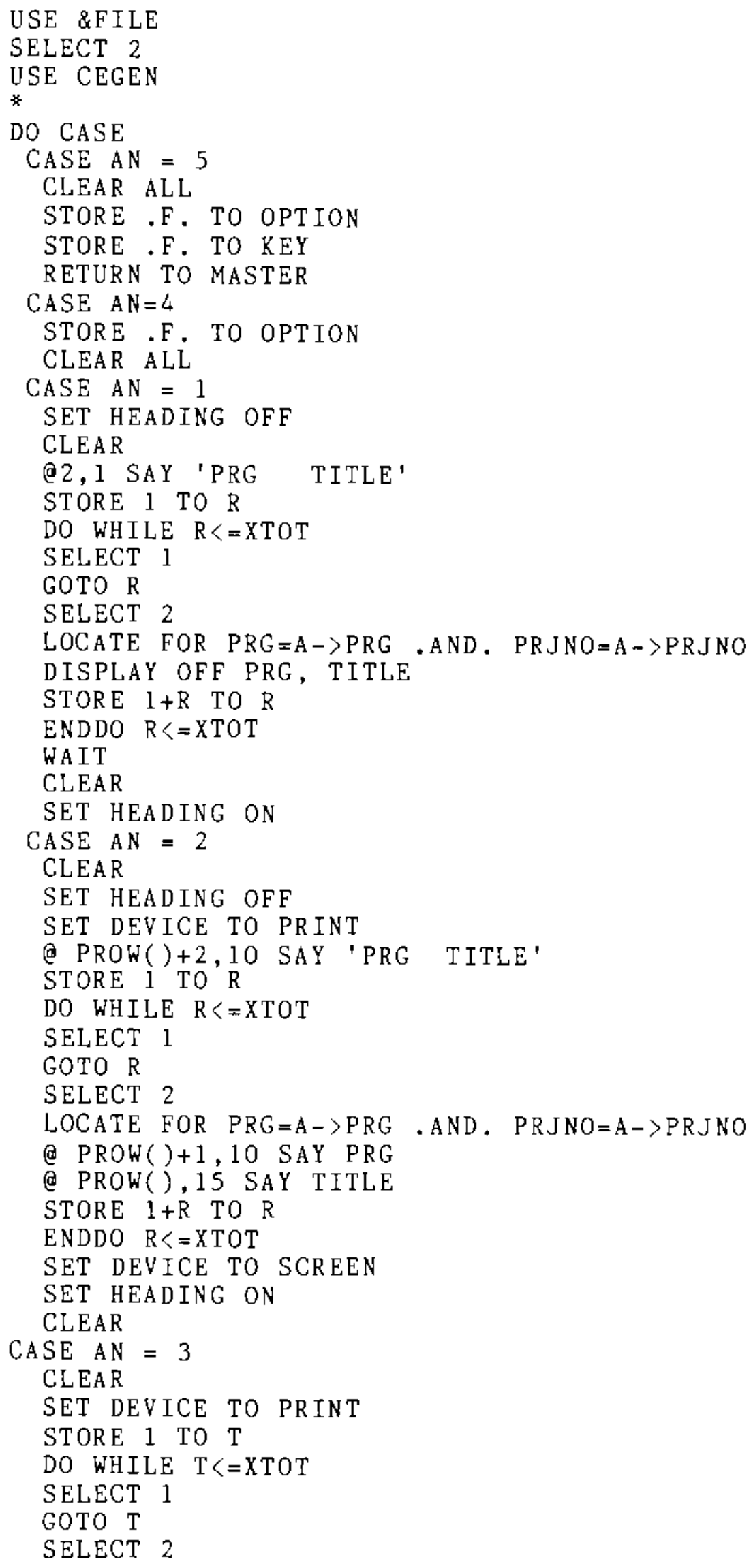


LOCATE FOR $P R G=A \rightarrow P R G$.AND. $P R J N O=A \rightarrow P R J N O$

STORE RECNO() TO R

DO REP 2

STORE $1+\mathrm{T}$ TO T

SET DEVICE TO SCREEN

ENDDO $\mathrm{T}<=$ XTOT

ENDCASE

ENDDO OPTION

ENDDO KEY

CLEAR ALL

*

RETURN 


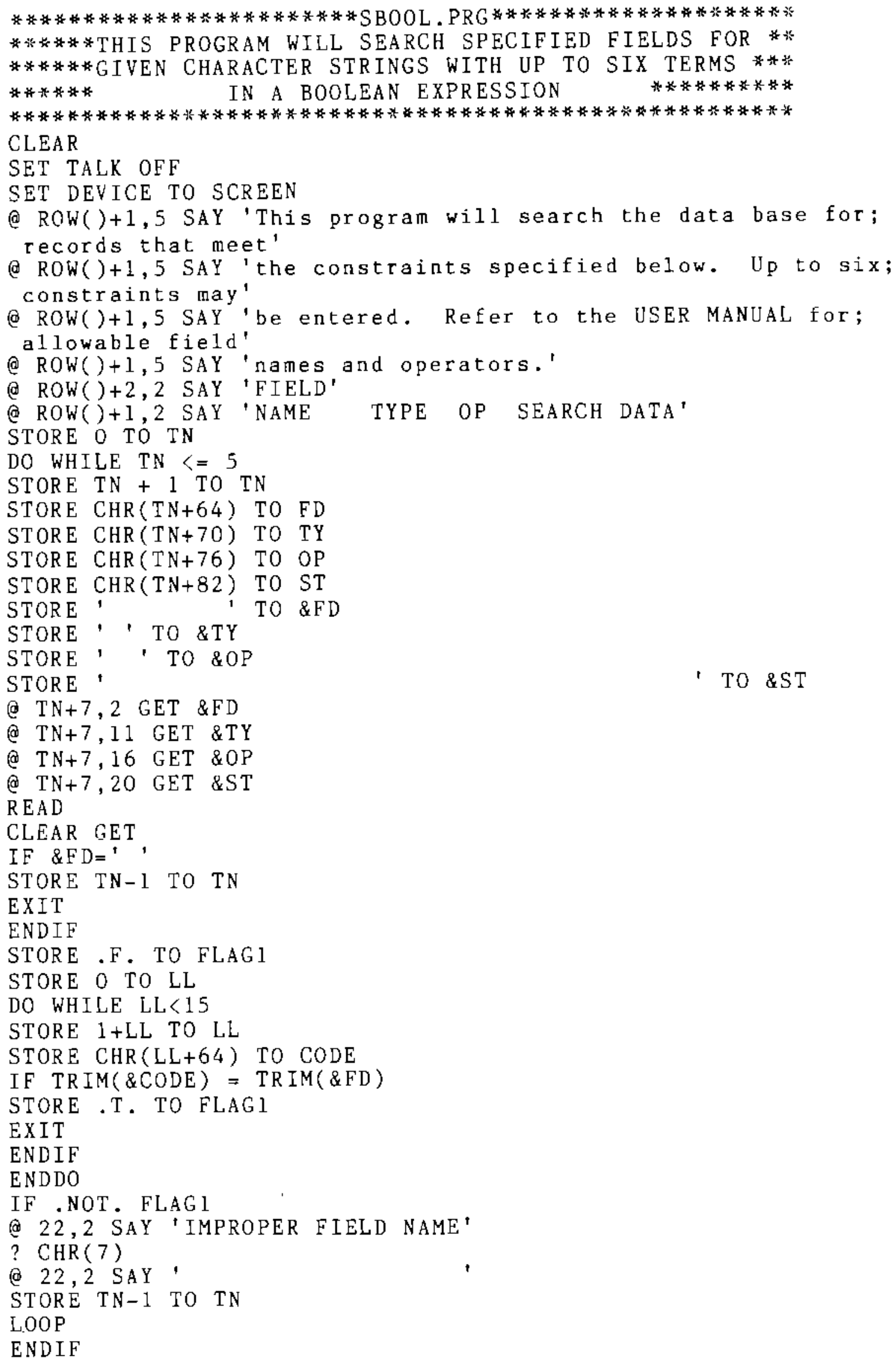




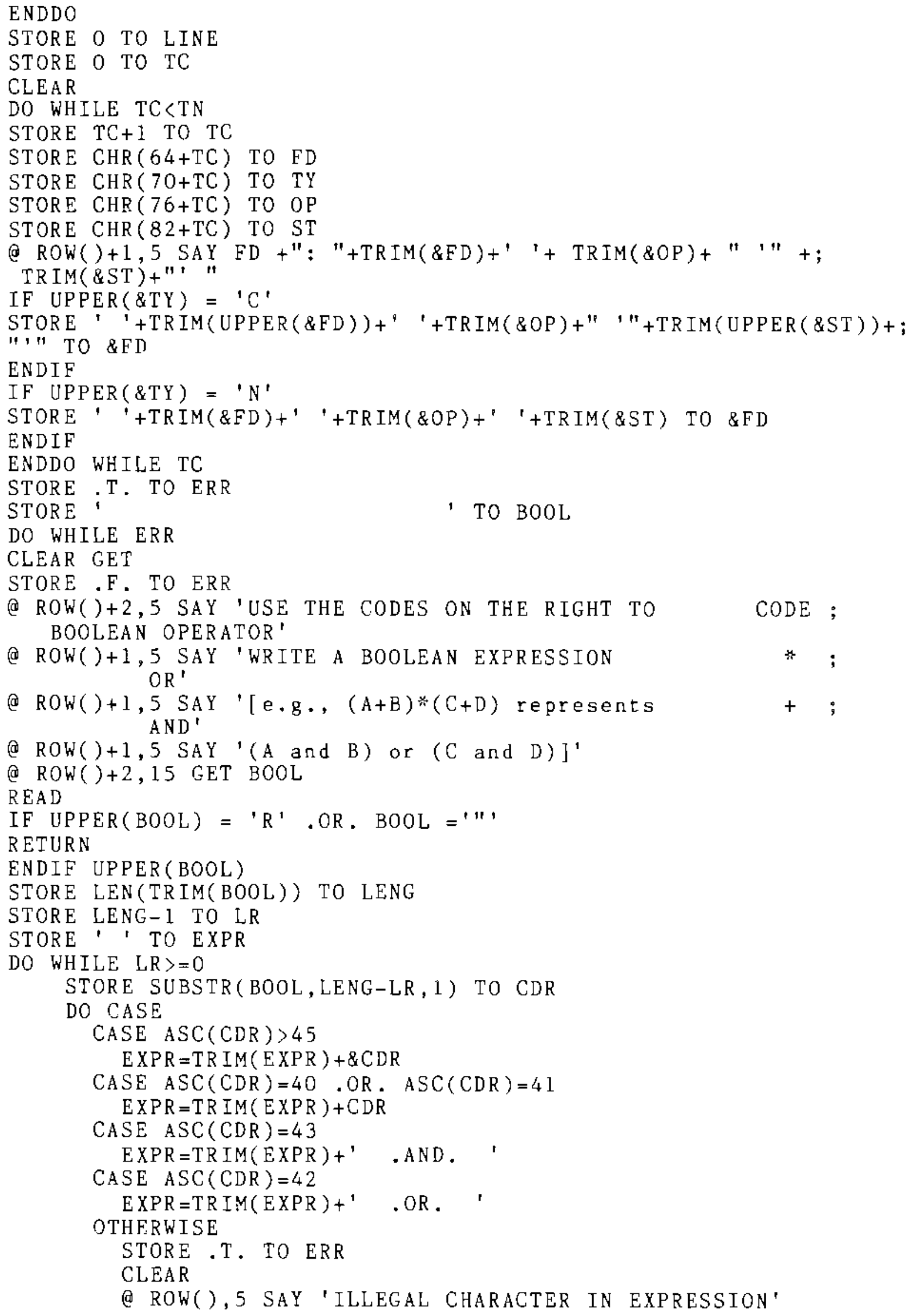




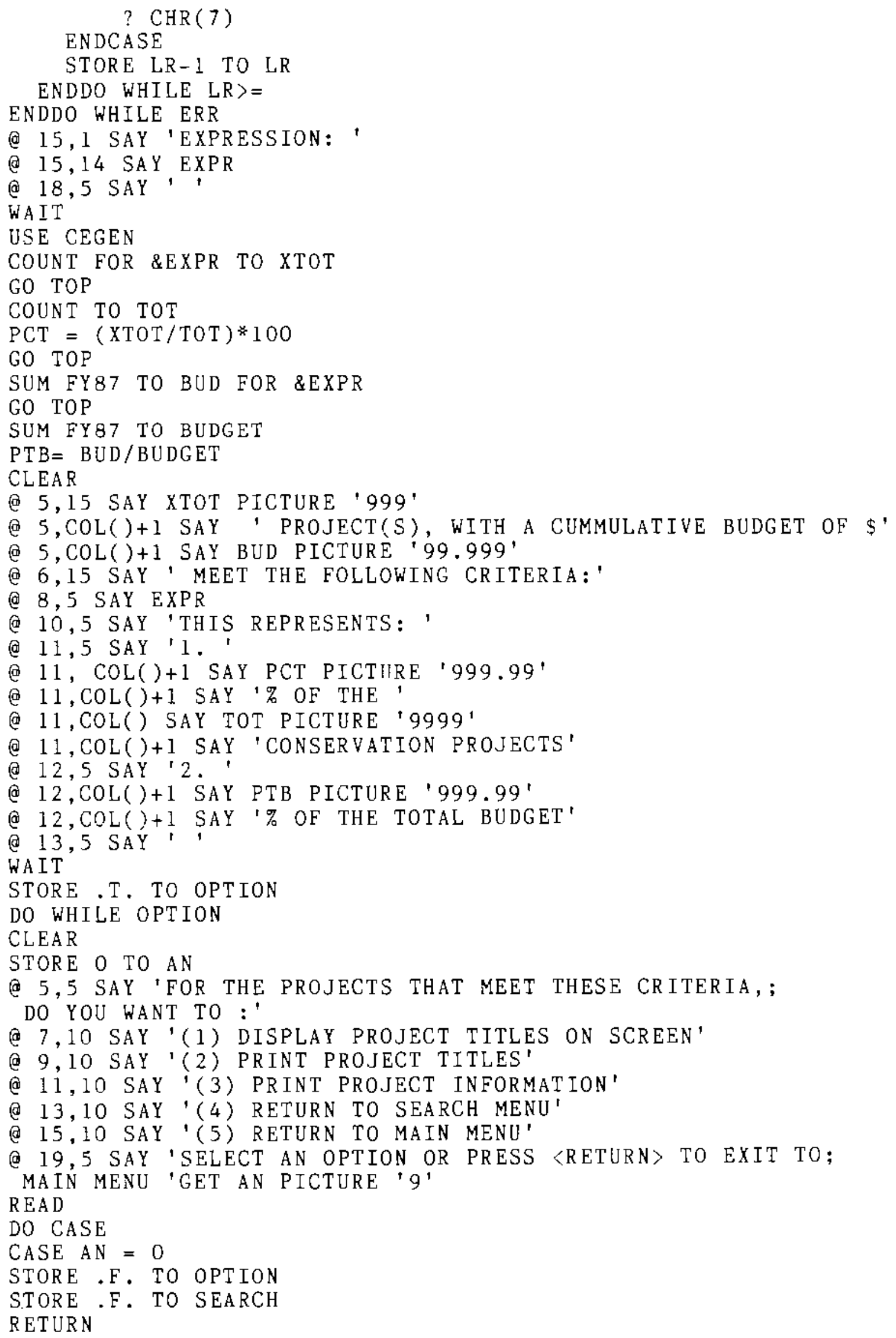




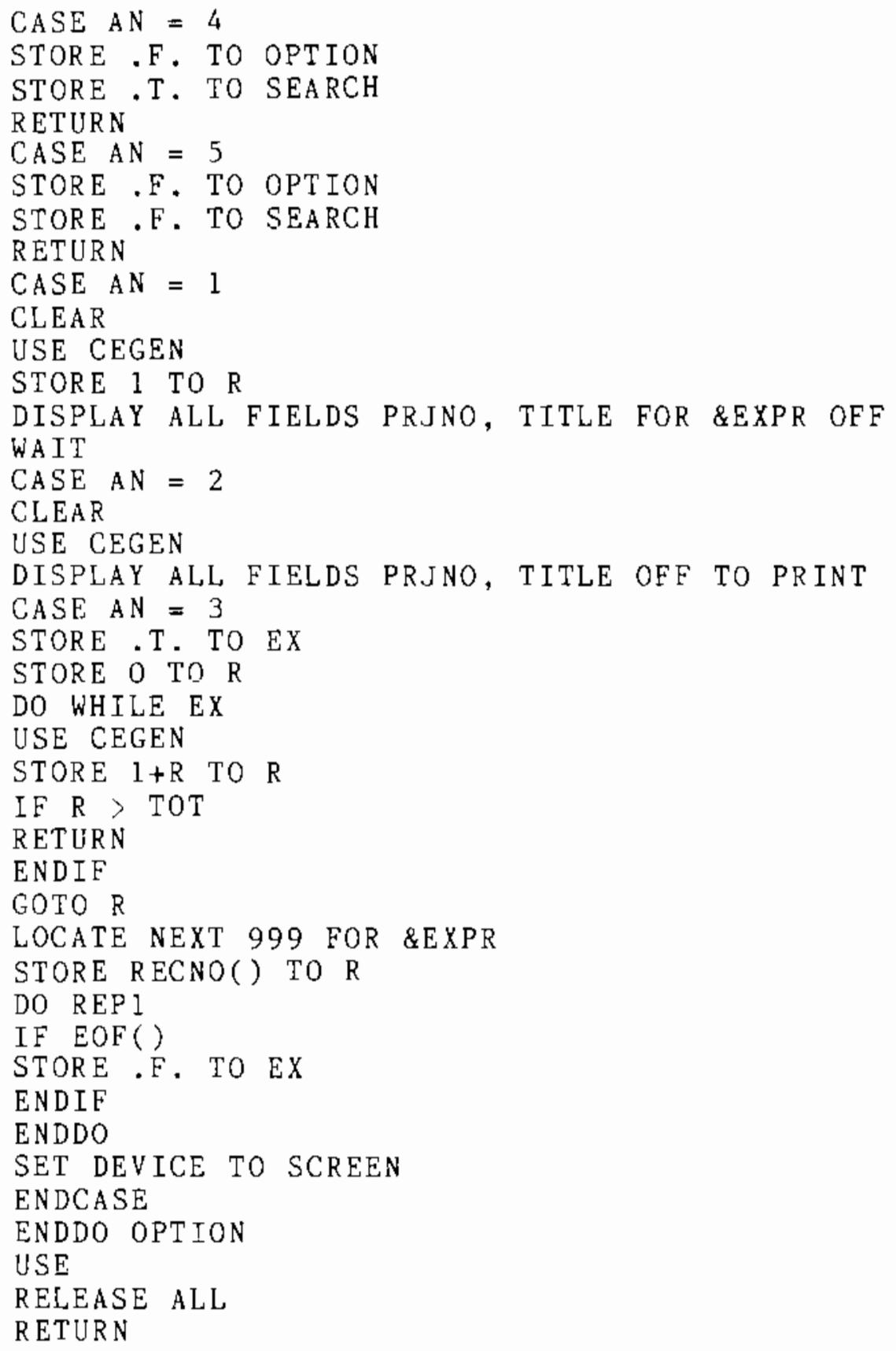




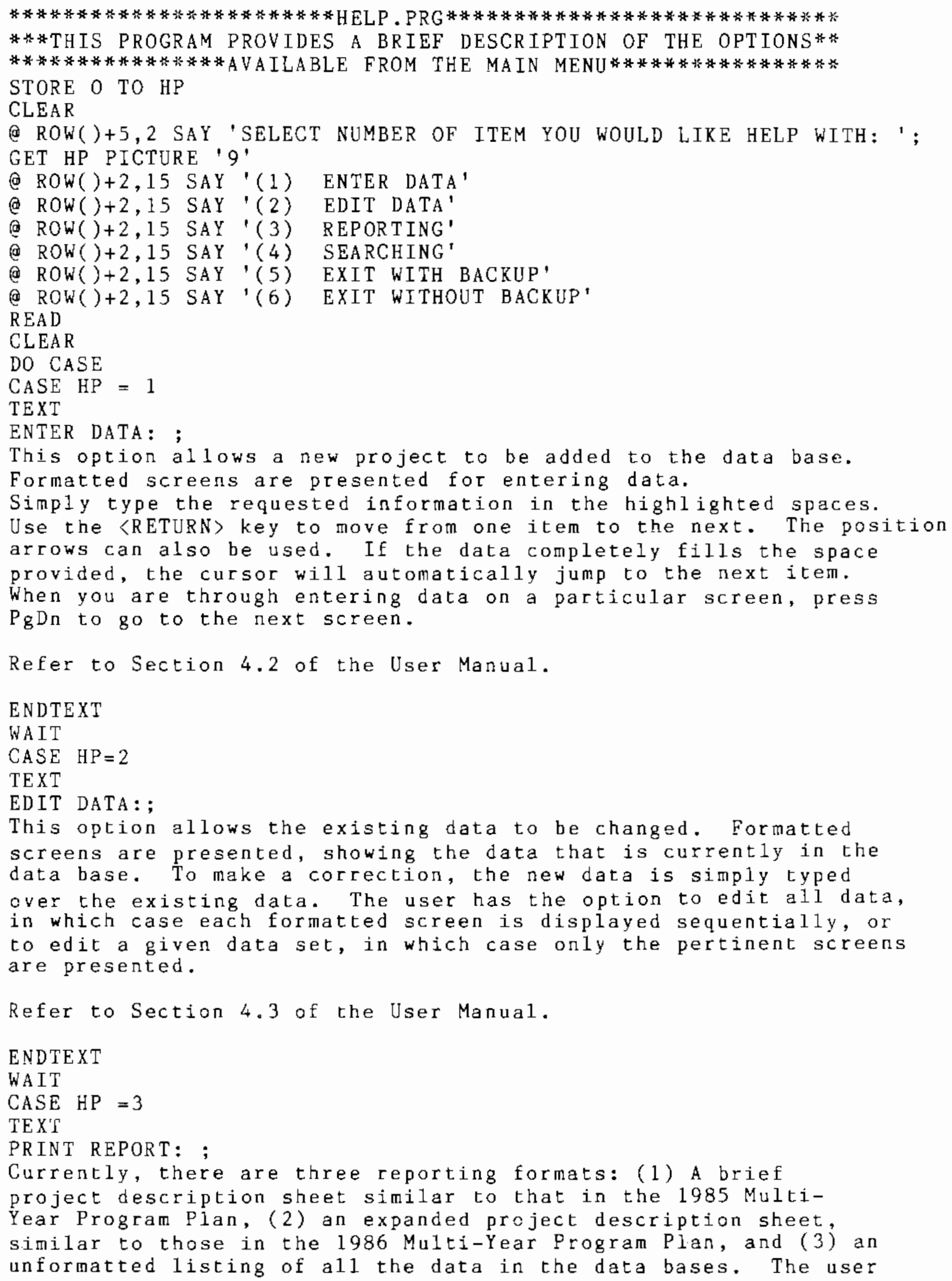




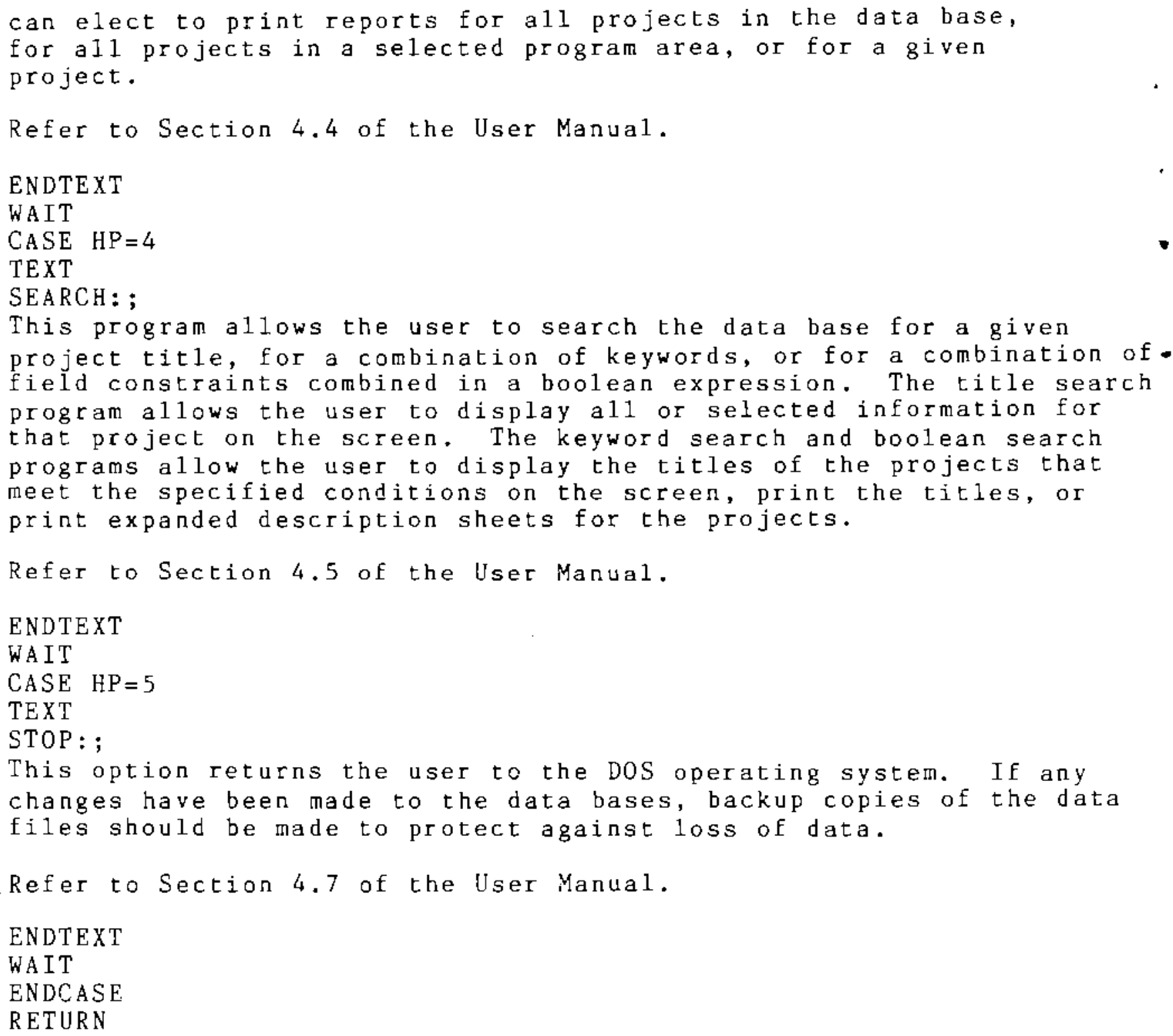




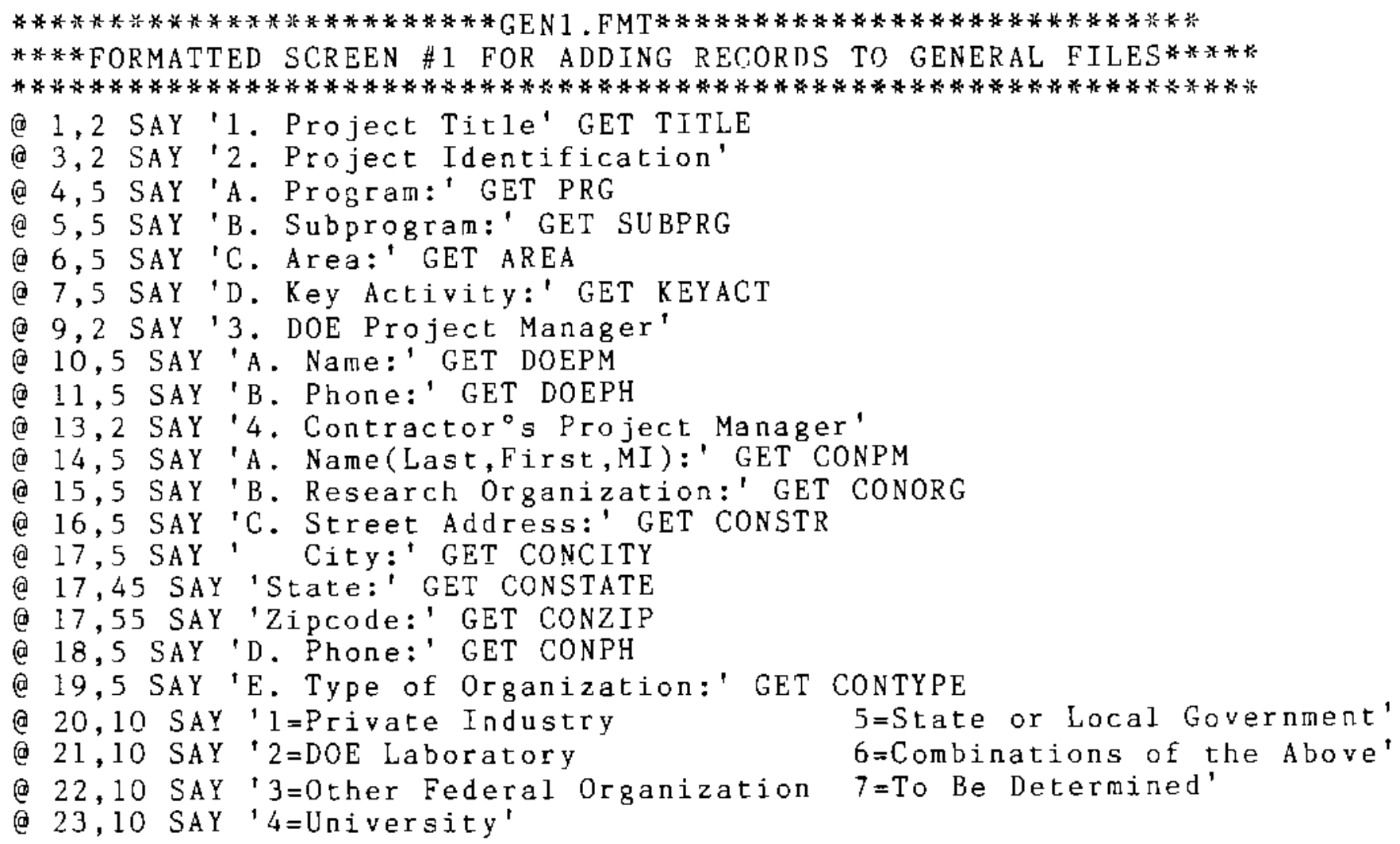




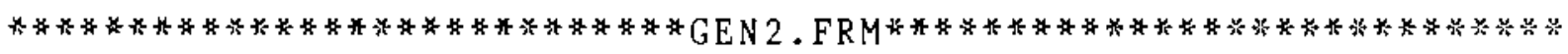
****FORMATTED SCREEN \#2 FOR ADDING RECORDS TO GENERAL FILES****

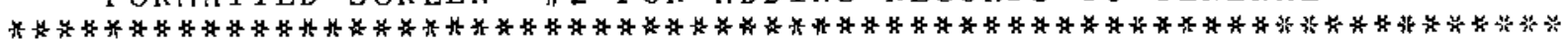
(1) $1,15 \mathrm{SAY}$ '* CONSERVATION PROJECT DATA BASE **'

(a 3,5 SAY 'PROJECT TITLE: '+ TITLE

(a) 5,5 SAY ' 7 . PROGRAM INTERRELATIONSHIPS'

a 7,10 SAY 'A. Mandated Project [Y/N]:' GET LAW

@ 9,10 SAY 'B. Program Support [Y/N]:' GET PRJSUP

(e) 11,10 SAY 'C. Necessary for Completion of Another Project; $[Y / N]:{ }^{\prime}$ GET OTHPRJ

@ 14,10 SAY ' If Yes, enter title of other project: '

(e) 15,14 GET OTHNAM 


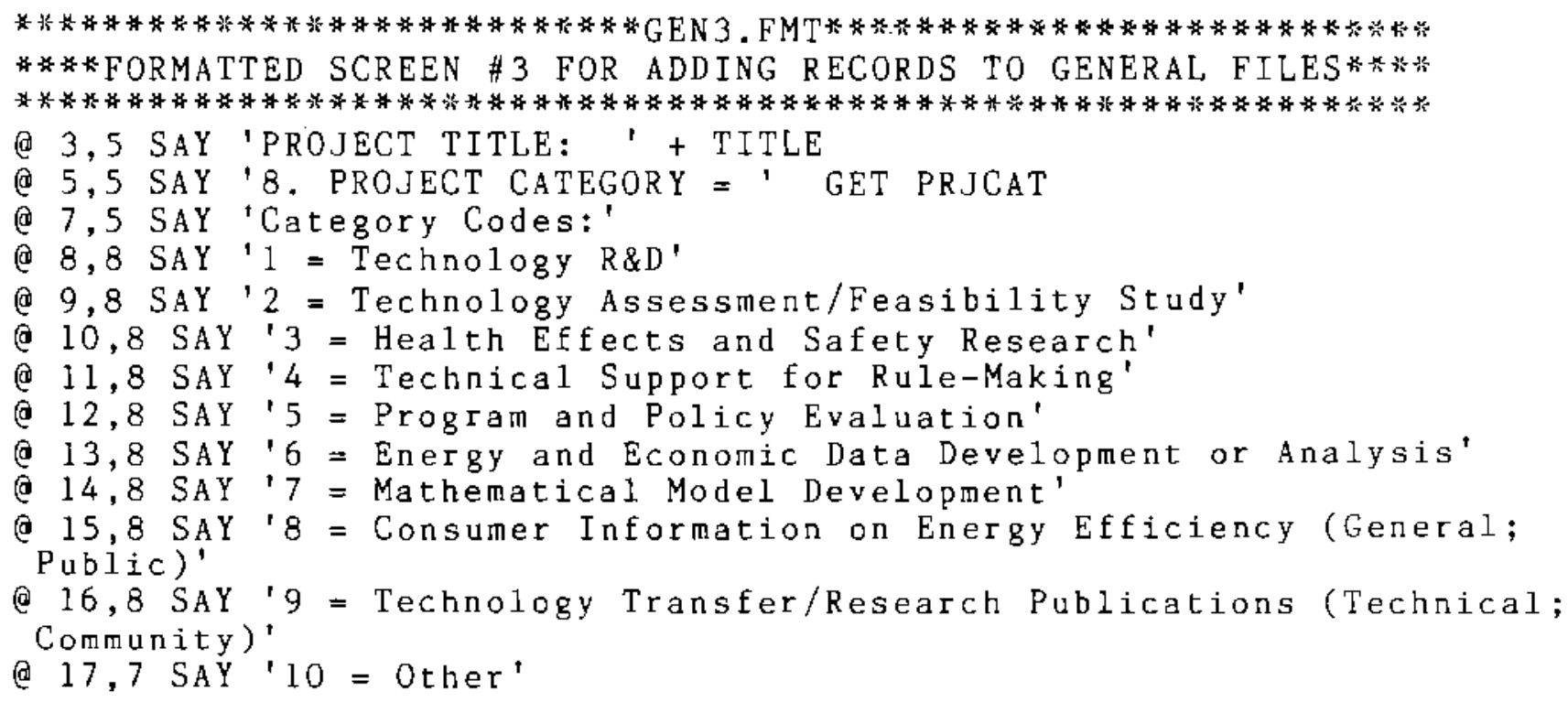



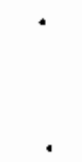

.

$\checkmark$

\section{•}

A. 52 


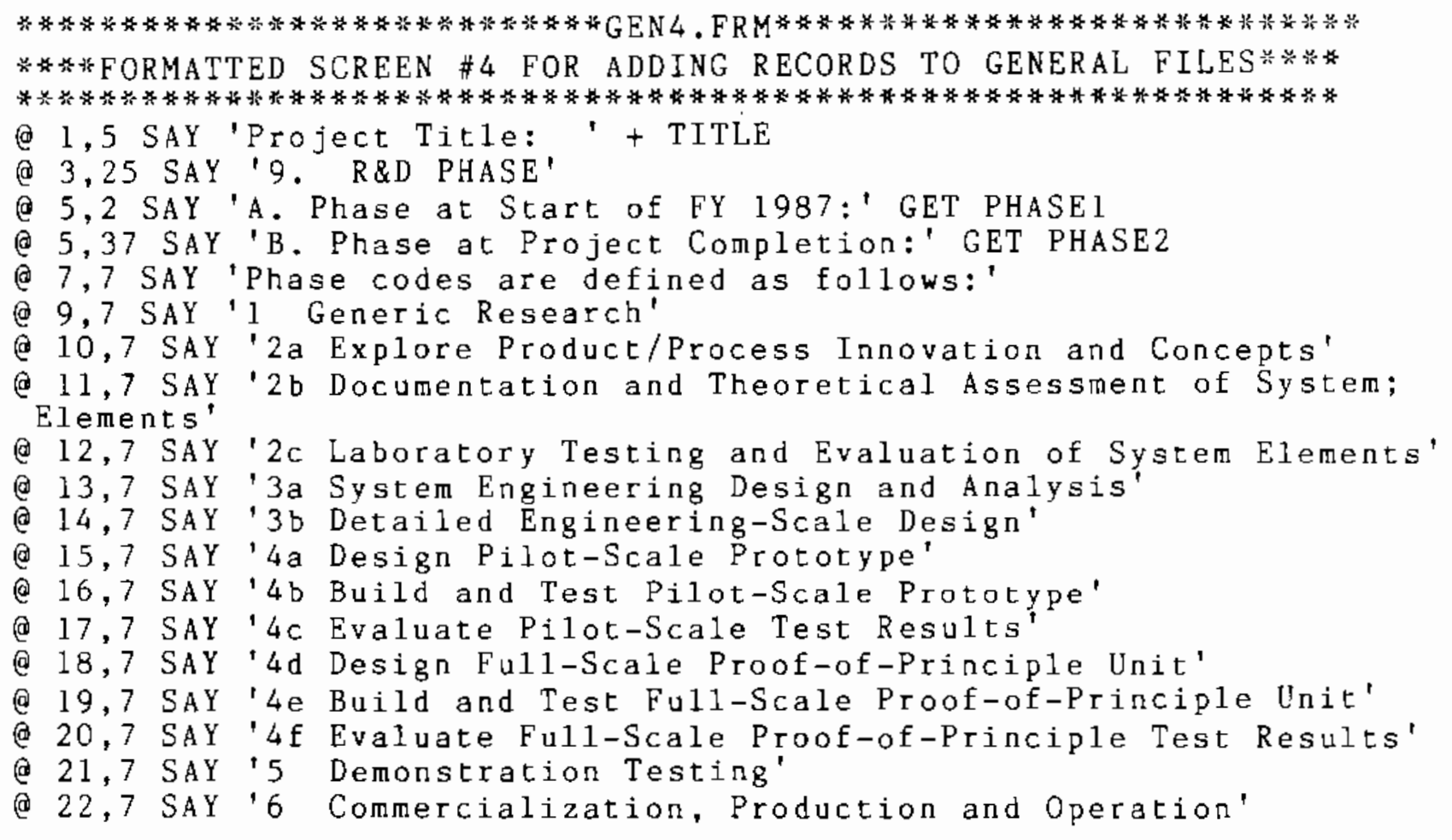


A. 54 


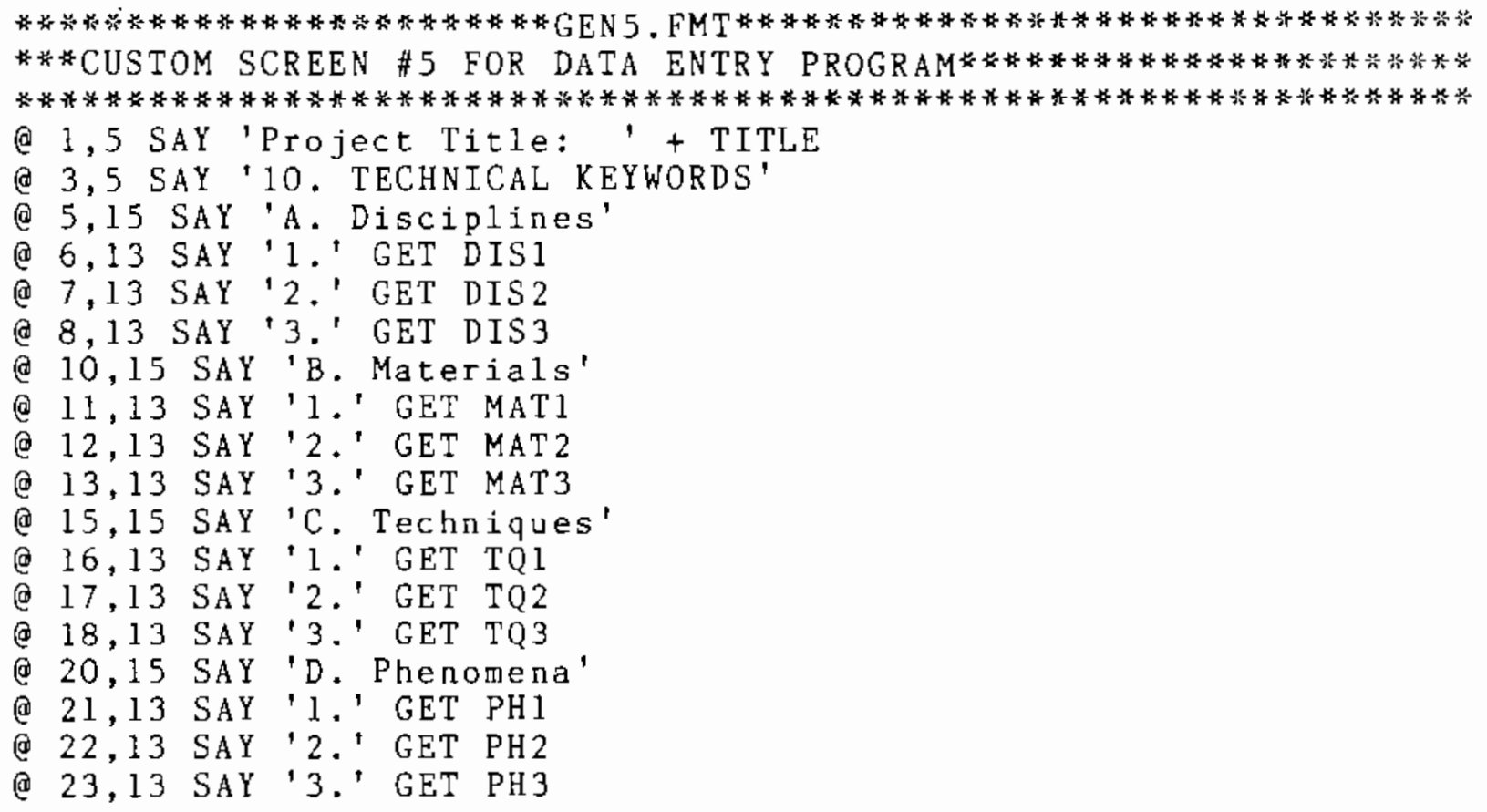




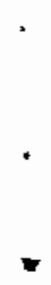

5

$\bullet$

1

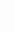

.

.

A. 56 


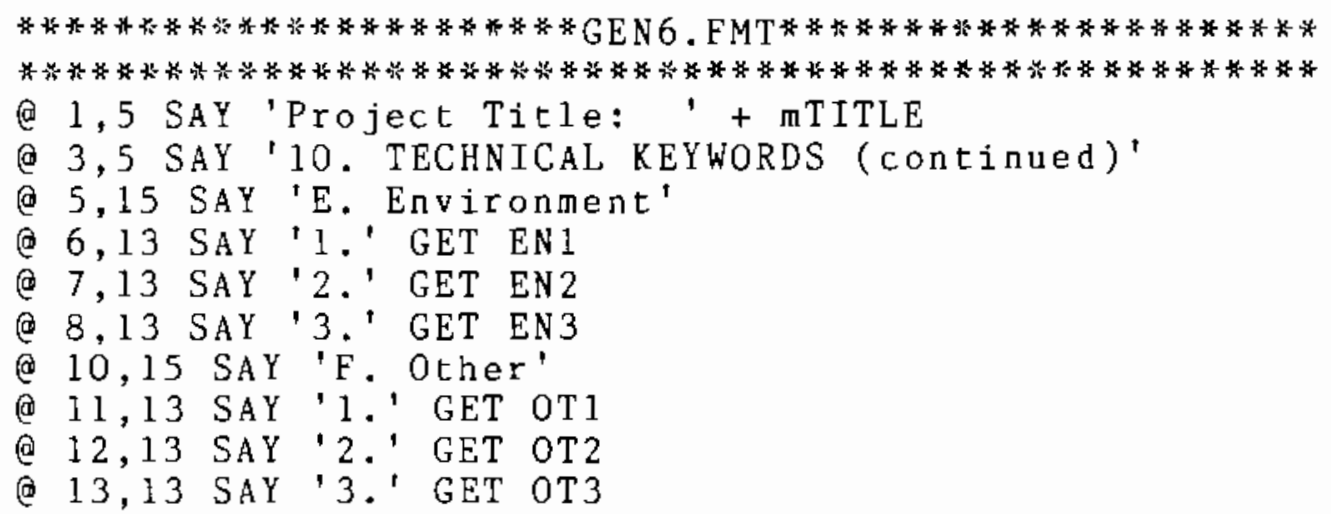




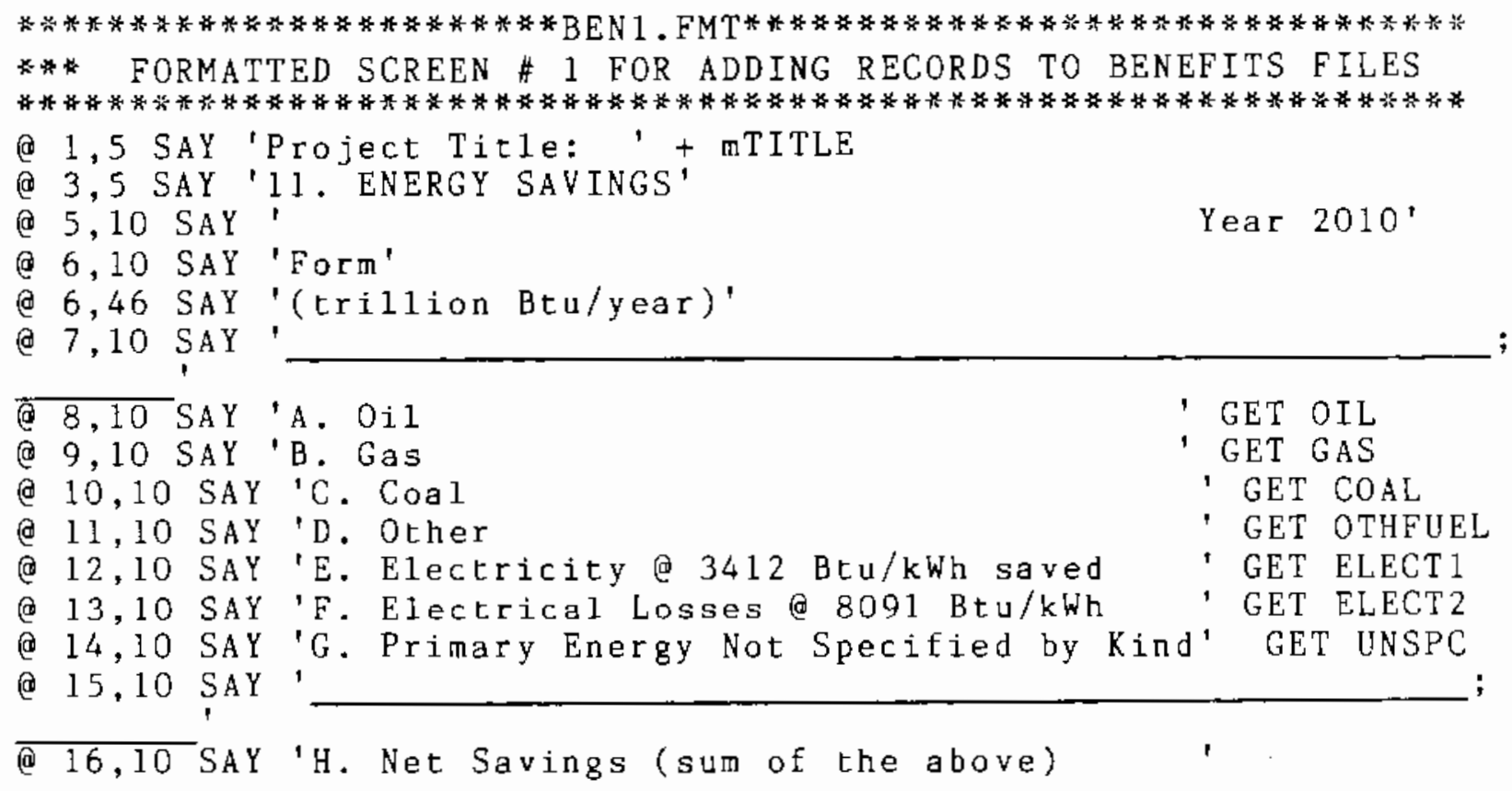




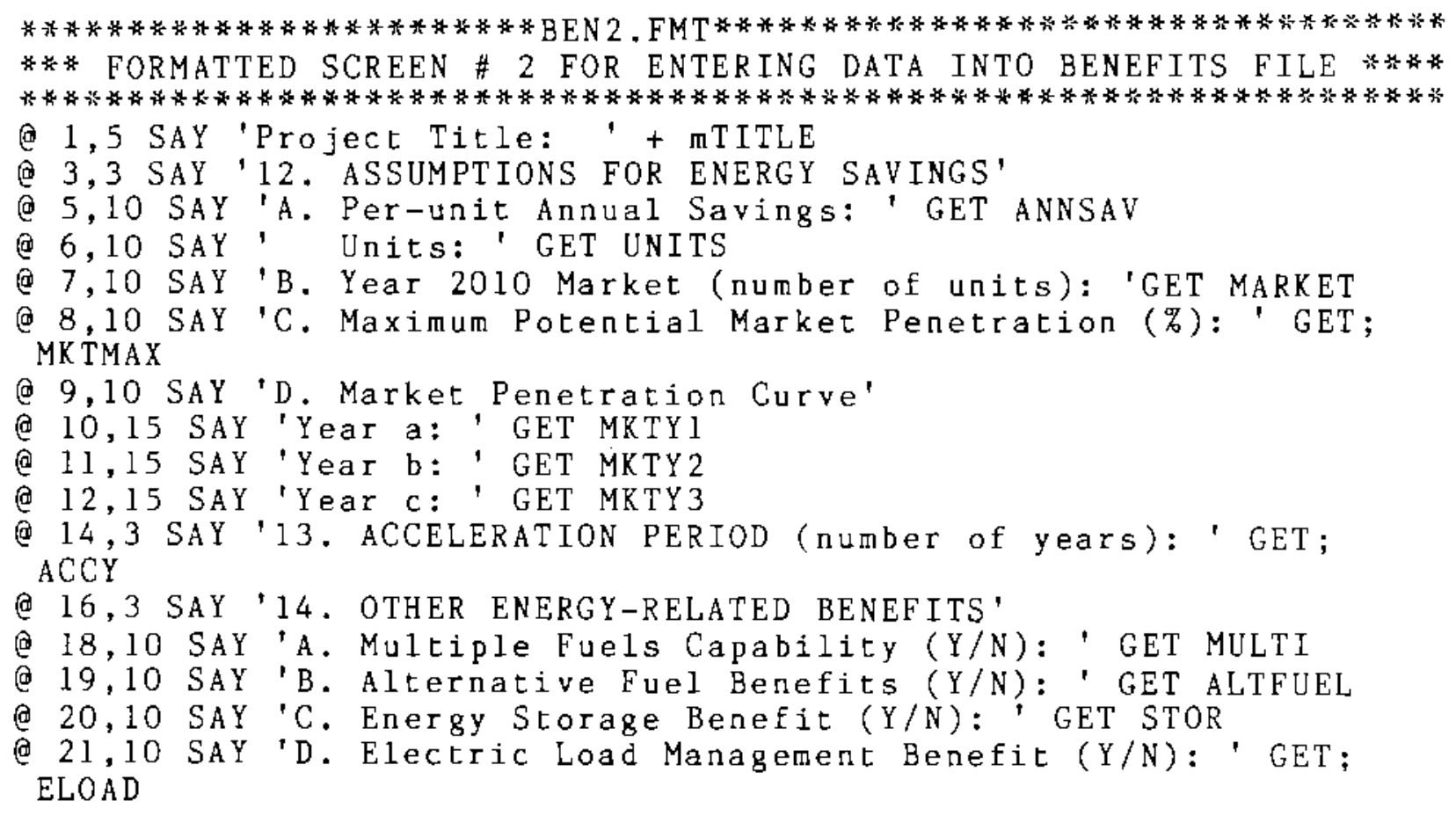


$\checkmark$

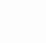




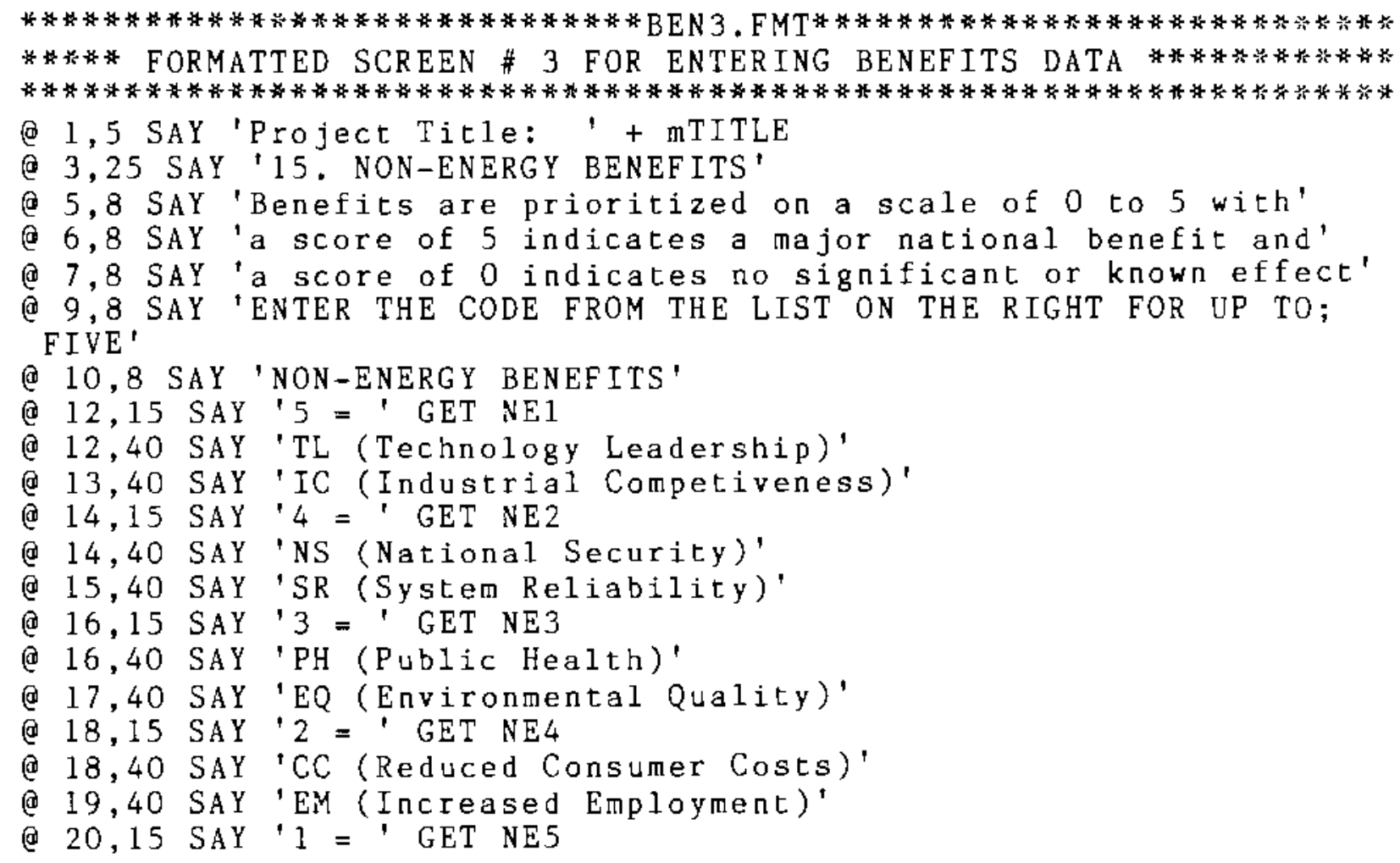


A. 64 


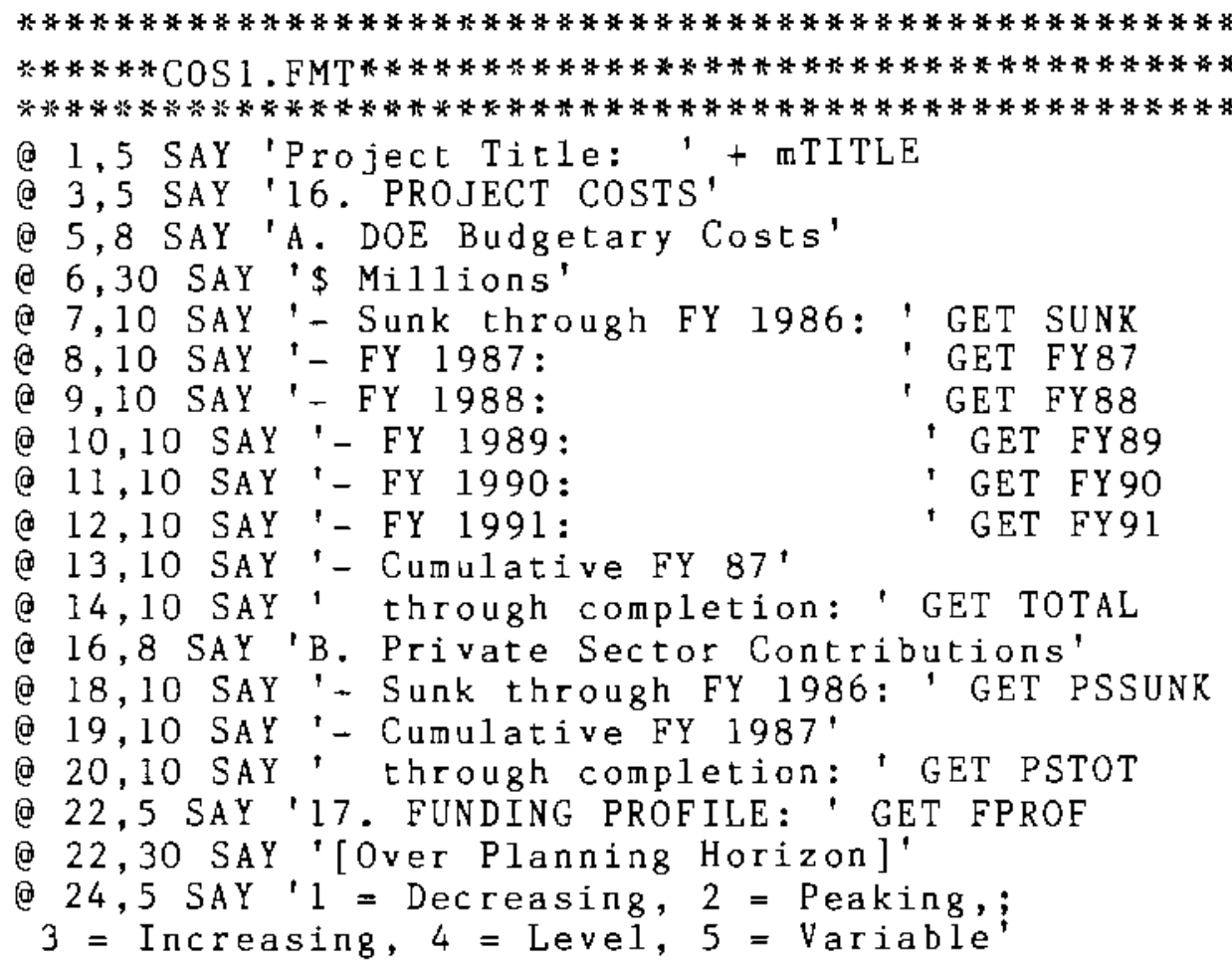




\section{APPENDIX B： SAMPLE REPORTS}

REPI.PRG - MULTI-YEAR PLAN PROJECT DESCRIPTION SHEETS 
Subprogram: INDUSTRIAL PROCESS EFFICIENCY

Area: MATERIALS PROCESSING

Project Category: TECHNOLOGY R\&D

DOE Project Manager: J.C. FULTON

(202) 252-8668

Description:

The program objective is the development of a process to directly cast steel strip in thin ( $1 / 2$ inch - 1 inch) thicknesses so that it requires minimum rolling to produce the total range of hot and cold rolled steel sheets with major energy savings.

Justification:

This program involves long-range, high-risk technology requiring extensive funds to demonstrate feasibility. The industry, due to worldwide product competition, does not have the funds to pursue the development.

Program Interrelationships:

This project is mandated by law.

R\&D Phase:

1) At Start of FY87: Laboratory Testing and Evaluation of System Elements

2) At Program Completion:

Evaluate Pilot-Scale Test Resuits

Energy Savings Benefits:

Year 2010

Form (trillion Btu/year)

\begin{tabular}{lr} 
Oil & 50.0 \\
Gas & 50.0 \\
Coal & 100.0 \\
\hline Net Savings (sum of the above) & 200.0
\end{tabular}


Non-Energy Benefits (In order of importance):

- Industrial Competitiveness

- Reduced Consumer Costs

- Technology Leadership

- System Reliability

- Increased Employment

Project Costs:

DOE Budgetary Costs

$\$$ millions

Sunk through FY $86 . . . \cdots . . . .19 .000$

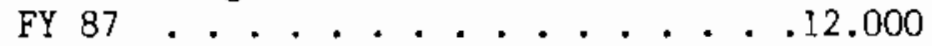

FY 88 . . . . . . . . . . . 10.500

FY 89 ............ 5.000

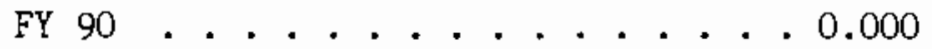

FY 91 . . . . . . . . . . 0.000

Cumulative FY 87 through Completion. . 27.500

Private Sector Contributions \$ millions

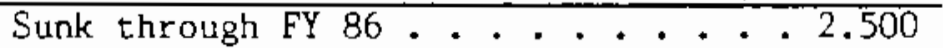

Cumulative FY 87 through Completion. . 4.500 
Program Office: INDUSTRY PROGRAM

Subprogram: INDUSTRIAL PROCESS EFFICIENCY

Area: $\quad$ MATERIALS PROCESSING

Project Title: THIN STRIP CASTING

Description:

The program objective is the development of a process to directly cast steel strip in thin ( $1 / 2$ inch - 1 inch) thicknesses so that it requires minimum rolling to produce the total range of hot and cold rolled steel sheets with major energy savings.

Justification:

This program involves long-range, high-risk technology requiring extensive funds to demonstrate feasibility. The industry, due to worldwide product. competition, does not have the funds to pursue the development.

Costs:

Federal ( $\$$ Million): Cost to complete project is $\$ 27.500$ million

PRE-

FY 1987 FY $1987 \quad$ FY $1988 \quad$ FY $1989 \quad$ FY $1990 \quad$ FY 1991

$\frac{\text { Total }}{19.000} \quad \overline{12.000} \quad \overline{10.500} \quad \frac{}{5.000} \quad \overline{0.000} \quad \frac{1000}{0.000}$

H.Q. Point of Contact: J.C. FULTON

Telephone Number: (202) 252-8668 
Subprogram: INDUSTRIAL PROCESS EFFICIENCY

Area: MATERIALS PROCESSING

Project Category: TECHNOLOGY R\&D

DOE Project Manager: J.C. FULTON (202) 252-8668

Contractor ${ }^{\circ} \mathrm{s}$ Project Manager: MOORE, MICHAEL

U.S.STEEL TECHNICAL CENTER

1 TECH CENTER DRIVE

MONROEVILLE, PA 15146

Type of Organization: 1

Description:

The program objective is the development of a process to directly cast steel strip in thin ( $1 / 2$ inch - 1 inch) thicknesses so that it requires minimum rolling to produce the total range of hot and cold rolled steel sheets with major energy savings.

Justification:

This program involves long-range, high-risk technology requiring extensive funds to demonstrate feasibility. The industry, due to worldwide product competition, does not have the funds to pursue the development.

Program Interrelationships:

This project is mandated by law.

R\&D Phase:

1) At Start of FY87: Laboratory Testing and Evaluation of System Elements

2) At Program Completion: Evaluate Pilot-Scale Test Results 
Energy Savings Benefits:

Year 2010

Form (trillion Btu/year)

$\begin{array}{lr}\text { Oil } & 50.0 \\ \text { Gas } & 50.0 \\ \text { Coal } & 100.0\end{array}$

Net Savings (sum of the above)

200.0

Assumptions:

Per-Unit Annual Savings: $\quad 6700000$

Year 2010 Market (Number of Units): 30

Maximum Potential Market Penetration (\%): 50

Market Penetration Curve:

Year A: 1990

Year B: 2000

Year C: 2020

Acceleration Period (years): 10

Non-Energy Benefits (In order of importance):

o Industrial Competitiveness

- Reduced Consumer Costs

- Technology Leadership

- System Reliability

o Increased Employment

Project Costs:

DOE Budgetary Costs \$ millions

Sunk through FY 86........ . . . . . . .

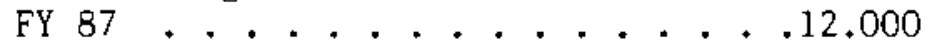

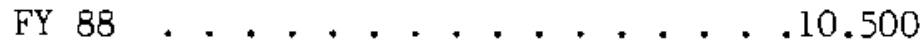

FY 89 .............. 5.000

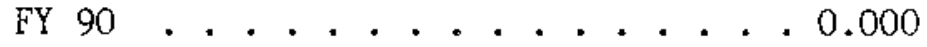

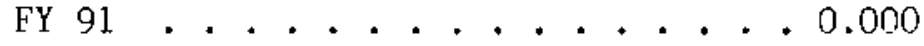

Cumulative FY 87 through Completion. .27.500

Private Sector Contributions \$ millions

Sunk through FY 86 . . . . . . . . 2.500

Cumulative FY 87 through Completion. . 4.500

Funding Profile: 1

Technical Keywords:

Disciplines: METALLURGY

MATERIALS SCIENCE

PHYSICS 
Materials: FERROUS METALS

$\begin{array}{ll}\text { Techniques: } & \text { MELTING } \\ & \text { CASTING } \\ & \text { COMPUTER SIMULATION }\end{array}$

Phenomena: HEAT TRANSFER

MATERIALS PROPERTIES

Environment: HIGH TEMPERATURE

MOLTEN METAL

Other: $\quad$ CHEMISTRY

MECHANICAL ENGINEERING

COMPUTER CONTROL

Notes:

Second contractor : Male, Slan T. Westinghouse Research Center 1310

Beulah Road Pittsburgh, PA 15235 Both projects use the same energy savings

base. Energy savings are not duplicative.

B. 7 
This appendix provides instructions for recovering from certain abnormal events that may occur during the execution of the CEDATA program. Included in this section are discussions of the following:

- Abnormal Termination
- Disk Full Message
Loss of Data

ABNORMAL TERMINATION

The adaptation of any newly developed computer code raises the possibility of abnormal termination during the execution of the code. In the event that this should occur during the execution of CEDATA, a general message will be printed on the screen: (1) indicating the type of problem that has occurred and the program and/or subprogram(s) in which the problem occurred, and (2) asking the user whether the command file should be terminated.

When the screen asks whether or not to terminate the command file, the following steps should be taken:

1. Type $Y$ to terminate the command file.

2. Type CLEAR aLL to close any open fites.

3. Type DO CEDATA to restart the applications program.

4. If termination occurred during the data entry (ADO.PRG) or the data edit (EDIT.PRG) program, you should check the data base to see if the data you were entering before the termination has been stored. The edit program or the title search program can be used to display the project information on the screen for this check.

\section{DISK FULL MESSAGE}

Each time you add data to a data base or edit a data base, a backup file of the original data base is automatically made. The backup file has the same file name as the original file and the file extension. BAK. The storage of backup files will at times create a shortage of storage space on the disk (most likely to occur on a floppy disk). Data files should be backed up on separate disks as discussed in Section 4.7, rather than relying on these backup files, To prevent a disk fuil error message from occurring, the user can erase the backup files from the disk before entering the dBase III program by typing the following after the DOS prompt:

ERASE *.BAK* This el iminates all backup files on the current drive.

If insufficient storage space is encountered during program execution, the following message will appear:

Disk full when writing file - FILENAME

Abort, Ignore, or Delete old files (A, I or D)? 
Selecting the abort (A) option causes the program to terminate its attempt to copy the file. The following message will appear:

**WARNING* Data will probably be lost confin $(Y / N)$ ?

If you type $Y$, the data will be lost and the screen will display the dot prompt. Typing $\mathrm{N}$ will produce the disk full error message again.

Ignore

Selecting the ignore (I) option causes the program to reattempt to copy the file. Most likely this will be unsuccessful and the disk full error message will again be displayed.

Delete

Selecting the delete (D) option causes the program to sequentially display all of the files currently stored on the disk. The user is given the option of deleting each file as it appears on the screen in order to make more room on the disk. Files with file extension. BAK should be deleted first. After the entire list has been displayed, the program will automatically continue its attempt to copy the file. If sufficient space is still unavailable, the disk full error message will again appear.

\section{LDSS OF DATA}

Loss of data from floppy or hard disk files can occur as a result of power surges or operator error. Surge-protection devices can be used to prevent the occurrence of the first type of data loss. The possibility of the latter occurring can be reduced by becoming familiar with the applications progran and with dBase III. If inadvertent data loss occurs, the backup data base file can be copied to the master disk as follows:

IN ABASE III:

1. COPY FILE d1:FILENAME.EXT TO d2:FILENAME.EXT, where $\mathrm{d} 1$ and $\mathrm{d} 2$ are the source and destination drives, respectively.

2. The screen will state that the file already exists and will ask if you want to overwrite it. Overwriting will delete the faulty information and store the data from the backup file onto the master disk.

IN DOS:

1. COPY $d 1: F I L E N A M E . E X T d 2: F I L E N A M E . E X T$, where $d 1$ and $d 2$ are the source and destination drives, respectively.

2. The screen will state that one file has been copied. 
PHCODE: Phase of Research

\begin{tabular}{|c|c|}
\hline PHCDDE & PHRD \\
\hline $\begin{array}{l}1 \\
2 A \\
2 B \\
2 C \\
3 A \\
3 B \\
4 A \\
4 B \\
4 C \\
40 \\
4 E \\
4 F \\
5 \\
6\end{array}$ & $\begin{array}{l}\text { Generic Research } \\
\text { Explore Product/Process Innovation and Concepts } \\
\text { Documentation/Theoretical Assessment of System Elements } \\
\text { Laboratory Testing and Evaluation of System Elements } \\
\text { System Engineering Design and Analysis } \\
\text { Detailed Engineering-Scale Design } \\
\text { Design Pilot-Scale Prototype } \\
\text { Build and Test Pilot-Scale Prototype } \\
\text { Evaluate Pilot-Scale Test Results } \\
\text { Design Full-Scale Proof-of-Principle Unit } \\
\text { Build and Test Full-Scale Proof-of-Principle Unit } \\
\text { Evaluate Full-Scale Proof-of-Principle Test Results } \\
\text { Demonstration Testing } \\
\text { Commercialization }\end{array}$ \\
\hline
\end{tabular}

PRCODE: Program

PRG PRCDDE

BCS BUILDINGS AND CDMMUNITY SYSTEMS

TP TRANSPORTATIDN

IP INDUSTRY PROGRAM

ES ENERGY STDRAGE

EES ELECTRIC ENERGY SYSTEMS

ECUT ENERGY CONVERSIDN AND UTILIZATION TECHNOLOGY

\section{PJCODE: Project Category}

\begin{tabular}{cl} 
PRICAT & PJCODE \\
\cline { 1 - 1 } 1 & Technology R\&D \\
2 & Technology Assessment/Feasibility Study \\
3 & Health Effects and Safety Research \\
4 & Technical Support for Rul e-Making \\
5 & Program and Policy Planning and Evaluation \\
6 & Energy and Economic Data Devel opment or Analysis \\
7 & Mathematical Model Development \\
8 & Consumer Information on Energy Efficiency (General Public) \\
9 & Technology Transfer/Research Publications (Technical Com- \\
10 & munity) \\
& Other
\end{tabular}




\begin{tabular}{|c|c|}
\hline CON & DRC \\
\hline $\begin{array}{l}1 \\
2 \\
3 \\
4 \\
5 \\
6 \\
7\end{array}$ & $\begin{array}{l}\text { PRIVATE INDUSTRY } \\
\text { DOE LABORATORY } \\
\text { OTHER FEDERAL ORGANIZATION } \\
\text { UNIVERSITY } \\
\text { STATE OR LOCAL GOVERNMENT } \\
\text { COMBINATIONS OF TYPES } \\
\text { TO BE DE TERMINED }\end{array}$ \\
\hline
\end{tabular}

SPCOOE : Subprogran

SUBPRG SUBCODE

$\begin{array}{ll}\text { AF } & \text { ALTERNATIVE FUELS UTILIZATION } \\ \text { AMD } & \text { ADVANCED MATERIALS DEVELOPMENT } \\ \text { AS } & \text { APPLIANCE STANDARDS } \\ \text { ATT } & \text { ANALYSIS AND TECHNOLOGY TRANSFER } \\ \text { BER } & \text { BUILDING EQUIPMENT RESEARCH } \\ \text { BS } & \text { BUILDING SYSTEMS } \\ \text { CAB } & \text { CATALYSIS AND BIOTECHNOLOGY } \\ \text { CE } & \text { CAPITAL EQUIPMENT } \\ \text { COM } & \text { COMBUSTION } \\ \text { CS } & \text { COMMUNITY SYSTEMS } \\ \text { CT } & \text { CONVERSION TECHNOLOGY } \\ \text { EFE } & \text { ELECTRIC FIELD EFFECTS } \\ \text { EHV } & \text { ELECTRIC AND HYBRID VEHICLES } \\ \text { ES } & \text { ENERGY STORAGE } \\ \text { ETD } & \text { ELECTROCHEMICAL EXPLORATORY TECHNOLOGY DEVELOPMENT } \\ \text { FEM } & \text { FEDERAL ENERGY MANAGEMENT PROGRAM } \\ \text { IC } & \text { INDUSTRIAL COGENERATION } \\ \text { IO } & \text { IMPLEMENTATION AND DEPLOYMENT } \\ \text { INC } & \text { INNOVATIVE CONCEPTS } \\ \text { IPE } & \text { INDUSTRIAL PROCESS EFFICIENCY } \\ \text { MAT } & \text { MATERIALS } \\ \text { PCS } & \text { PHYSICAL AND CHEMICAL STORAGE } \\ \text { PD } & \text { PROGRAM DIRECTION } \\ \text { RCS } & \text { RESIDENTIAL CONSERVATION SERVICE } \\ \text { RRD } & \text { RELIABILITY R\&D } \\ \text { ST } & \text { SYSTEMS TECHNOLOGY } \\ \text { TBR } & \text { ELECTROCHEMICAL TECHNOLOGY BASE RESEARCH } \\ \text { TR } & \text { TRIBOLOGY } \\ \text { TSU } & \text { TRANSPORTATION UTILIZATION } \\ \text { VP } & \text { VEHICLE PROPULSION R\&D } \\ \text { WER } & \text { WASTE ENERGY REDUCTION } \\ & \end{array}$


ARCODE: Area

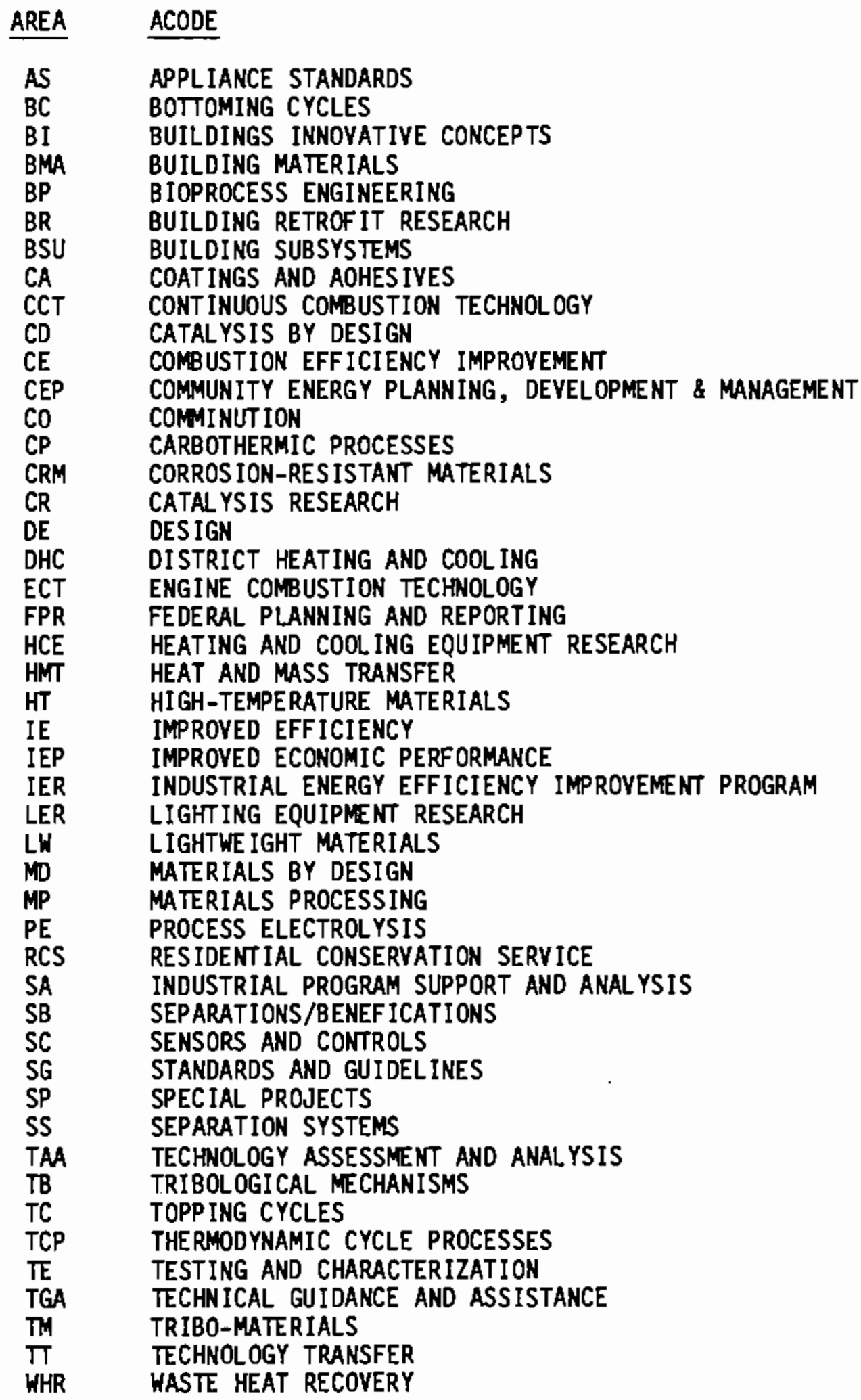




\section{DISTRIBUTION}

No. of

Copies

OFFSITE

Dr. Alan J. Streb

Department of Energy

office of Conservation

Forrestal Building

1000 Independence Avenue, S.W.

Washington, D.C. 20585

Dr. Robert Marlay

Department of Energy

Office of Conservation

Forrestal Building

1000 Independence Avenue, S.W.

Washingtor, D.C. 20585

30 DOE Technical Information Center

Mr. James E. Reed

Vice President

Energetics, Inc.

9210 Route 108

Columbia, Maryland 21045
No, of

Copies

ONSITE

2 DOE Richland Operations Office

H. E. Ransom/R. A. ATmquist

D. R. Segna

64 Pacific Northwest Laboratory

C. H. Bloomster

J. W. Currie

L. L. Fassbender (25)

R. M. Fleischman

B. A. Garrett-Price (25)

N. L. Moore

Economics Library (3)

Technical Information Files (5)

Publishing Coordination (2) (MH) 
